\title{
Nevada Test Site 2006 Waste Management Monitoring Report Area 3 and Area 5 Radioactive Waste Management Sites
}

\section{June 2007}

Prepared for:

U.S. Department of Energy National Nuclear Security Administration Nevada Site Office

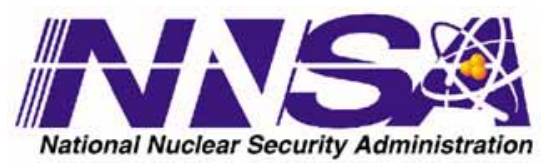

Prepared by:

National Security Technologies, LLC Las Vegas, Nevada

National Security Technologiesuc 


\title{
DISCLAIMER
}

Reference herein to any specific commercial product, process, or service by trade name, trademark, manufacturer, or otherwise does not necessarily constitute or imply its endorsement, recommendation, or favoring by the United States Government or any agency thereof or its contractors or subcontractors.

Available for sale to the public, in paper, from:

\author{
U.S. Department of Commerce \\ National Technical Information Service \\ 5285 Port Royal Road \\ Springfield, VA 22161 \\ Phone: (800) 553-6847 \\ Fax: (703) 605-6900 \\ E-mail: orders@ntis.gov \\ Online Ordering: http://www.ntis.gov/ordering.htm
}

Available electronically at http://www.osti.gov/bridge

Available for a processing fee to the U.S. Department of Energy and its contractors, in paper, from:

U.S. Department of Energy

Office of Scientific and Technical Information

P.O. Box 62

Oak Ridge, TN 37831-0062

Phone: (865) 576-8401

Fax: (865) 576-5728

E-mail: reports@adonis.osti.gov 


\section{Nevada Test Site 2006 Waste Management Monitoring Report Area 3 and Area 5 Radioactive Waste Management Sites}

\section{June 2007}

Work Performed Under

Contract No. DE-AC52-06NA25946

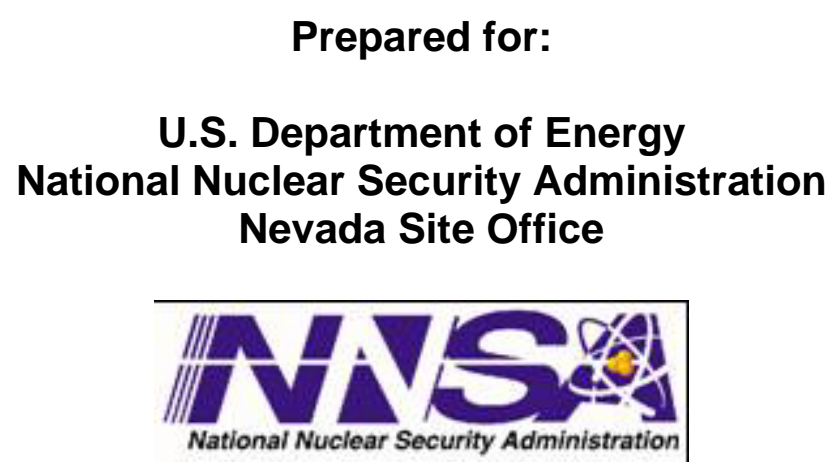

Prepared by:

National Security Technologies, LLC

Las Vegas, Nevada

$\underset{\substack{\text { Nision. Sonvice } \\ \text { Parthership }}}{\text { Natity Technologies } u c}$ 


\section{This Page Intentionally Left Blank}




\section{EXECUTIVE SUMMARY}

Environmental monitoring data were collected at and around the Area 3 and Area 5 Radioactive Waste Management Sites (RWMSs) at the Nevada Test Site. These data are associated with radiation exposure, air, groundwater, meteorology, vadose zone, subsidence, and biota. This report summarizes the 2006 environmental data to provide an overall evaluation of RWMS performance and to support environmental compliance and performance assessment (PA) activities. Some of these data (e.g., radiation exposure, air, and groundwater) are presented in other reports (U.S. Department of Energy, 2006; Warren and Grossman, 2007; National Security Technologies, LLC, 2007).

Direct radiation monitoring data indicate that exposure levels around the RWMSs are at or below background levels. Air monitoring data at the Area 3 and Area 5 RWMSs indicate that tritium concentrations are slightly above background levels. There is no detectable man-made radioactivity by gamma spectroscopy, and concentrations of americium and plutonium are only slightly above detection limits at the Area 3 RWMS. Measurements at the Area 5 RWMS show that radon flux from waste covers is no higher than natural radon flux from undisturbed soil in Area 5. Groundwater monitoring data indicate that the groundwater in the uppermost aquifer beneath the Area 5 RWMS is not impacted by facility operations. Precipitation during 2006 totaled 98.6 millimeters (mm) (3.9 inches [in.]) at the Area 3 RWMS and $80.7 \mathrm{~mm}$ (3.2 in.) at the Area 5 RWMS. Soil-gas tritium monitoring continues to show slow subsurface migration consistent with previous results. Moisture from precipitation at Area 5 remains at the bottom of the bare-soil weighing lysimeter, but this same moisture has been removed from the vegetated weighing lysimeter by evapotranspiration. Vadose zone data from the operational waste pit covers show that evaporation continues to slowly remove soil moisture that came from the heavy precipitation in the fall of 2004 and the spring of 2005 . The vegetated final cover at U-3ax/bl continues to remove moisture by evapotranspiration. There was no drainage through 2.4 meters (8 feet) of soil from the Area 3 drainage lysimeters that received only natural precipitation or were vegetated. Water drained from the bare-soil Area 3 drainage lysimeter that received three times natural precipitation. All 2006 monitoring data indicate that the Area 3 and Area 5 RWMSs are performing within expectations of the model and parameter assumptions for the facility PAs. 


\section{This Page Intentionally Left Blank}




\section{CONTENTS}

Executive Summary .......................................................................................................... iii

List of Figures and Table ..................................................................................................... vi

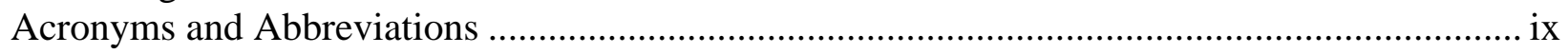

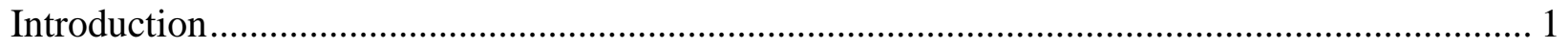

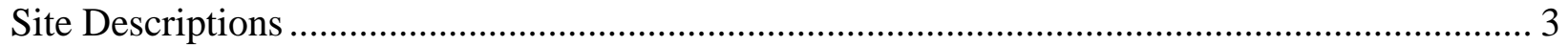

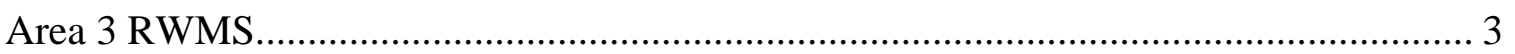

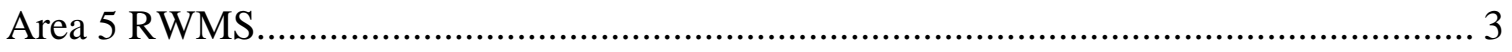

Hydrologic Conceptual Model of the Area 3 and Area 5 RWMSs ................................. 5

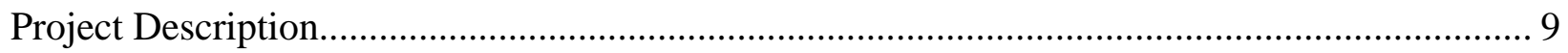

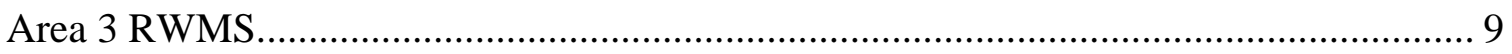

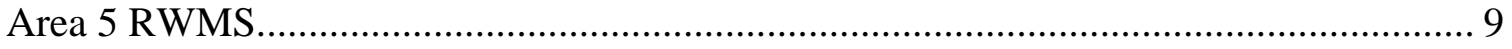

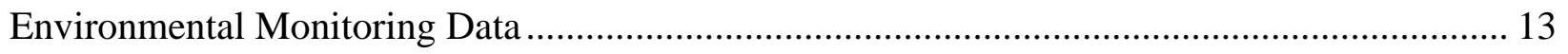

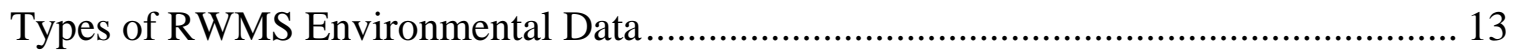

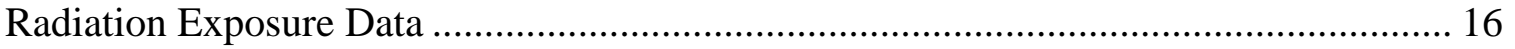

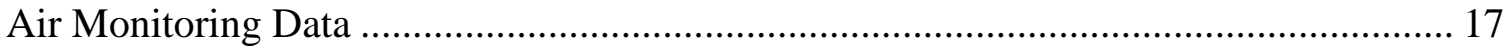

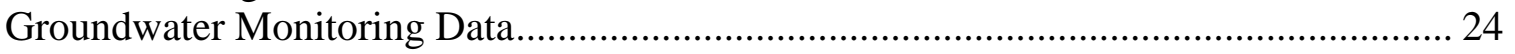

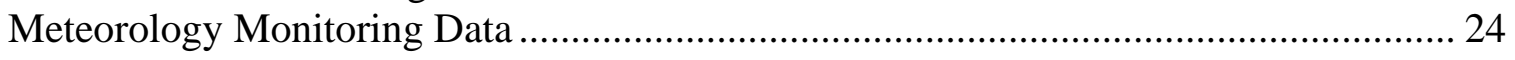

Vadose Zone Monitoring Data.............................................................................. 31

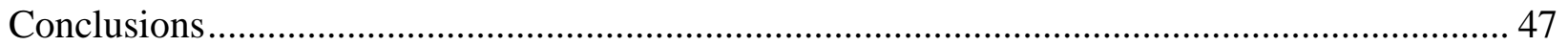

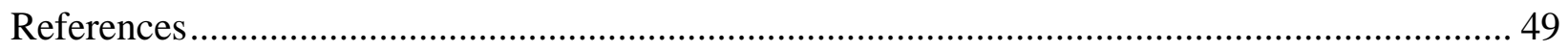

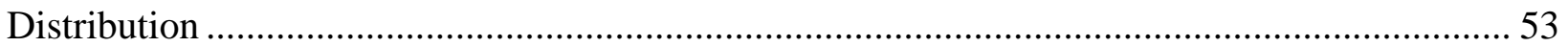




\section{List of Figures and Table}

Figure 1 Location of the Area 3 and Area 5 RWMSs on the NTS.........................

Figure 2 Vadose Zone Hydrologic Conceptual Models of the Area 3 and

Area 5 RWMSs............................................................ 6

Figure 3 Monitoring Locations at the Area 3 RWMS................................ 10

Figure $4 \quad$ Monitoring Locations at the Area 5 RWMS.................................. 11

Figure $5 \quad$ Location of the Area 5 Pilot Wells and Weighing Lysimeter Facility...............14

Figure $6 \quad$ Annual Exposure Rates at the Area 3 RWMS during 2006....................... 17

Figure $7 \quad$ Quarterly Average Daily Exposure Rates at the Area 3 RWMS and

NTS Background TLD Locations, 1998 to $2006 \ldots \ldots \ldots \ldots \ldots \ldots \ldots \ldots \ldots \ldots \ldots \ldots . . . . . .18$

Figure 8 Quarterly Average Daily Exposure Rates at the Area 5 RWMS and

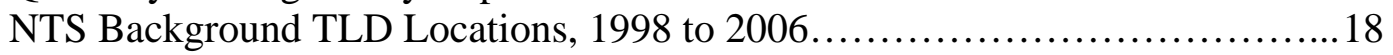

Figure $9 \quad$ Tritium Concentration in Air............................................ 20

Figure $10 \quad{ }^{241} \mathrm{Am}$ Concentrations in Air at the RWMSs and Other Locations................220

Figure $11 \quad{ }^{238} \mathrm{Pu}$ Concentrations in Air at the RWMSs and Other Locations....................21

Figure $12 \quad{ }^{239}$ Plutonium Concentrations in Air at the RWMSs and Other Locations..........21

Figure 13 Radon Flux Measurement Locations in Area 3............................... 20

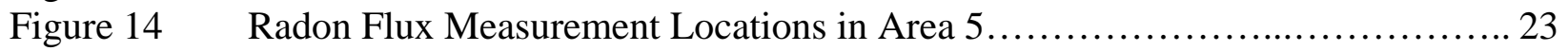

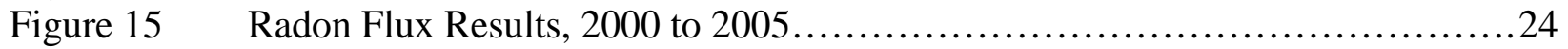

Figure 16 Groundwater Elevation Measurements Recorded at the Three Area 5

RWMS Pilot Wells by Tagging...........................................25

Figure 17 Daily Maximum and Minimum Air Temperatures at the Area 3

and Area 5 RWMSs......................................................26

Figure 18 Daily Average Humidity Recorded at Area 3 and Area 5 RWMS

Meteorology Stations...................................................26

Figure 19 Daily Average Barometric Pressure Recorded at Area 3 and

Area 5 RWMS Meteorology Stations......................................27

Figure 20 Daily Wind Speed Recorded at the Area 3 Meteorology Station at

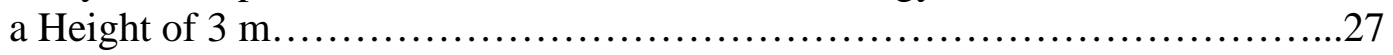

Figure 21 Daily Wind Speed Recorded at the Area 5 RWMS Meteorology Station

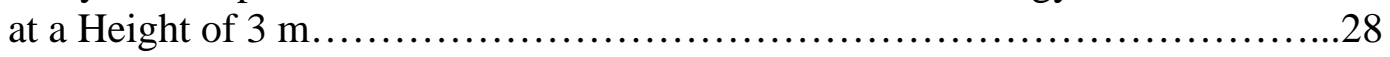

Figure 22 Wind Rose Diagram for the Area 3 RWMS Meteorology Station................ 29

Figure 23 Wind Rose Diagram for the Area 5 RWMS Meteorology Station................ 29

Figure 24 Daily Precipitation Recorded at the Area 3 RWMS Meteorology Station......... 30

Figure 25 Daily Precipitation Recorded at the Area 5 RWMS Meteorology Station......... 30

Figure 26

Figure 27

Figure 28

Figure 29

Figure 30

Figure 31 Historical Precipitation Record for the Area 3 Buster-Jangle Y and the Area 3 RWMS.................................................. 32

Historical Precipitation Record for Area Well 5B and the Area 5 RWMS......... 32

Soil Gas Tritium Concentrations with Depth at GCD-05U......................... 34

Soil Gas Tritium Concentration at Each Depth in GCD-05U......................35

Weighing Lysimeter and Precipitation Data from March 1994 to

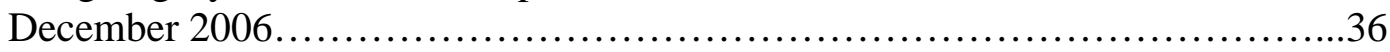

Cumulative Precipitation, ET, E, and Change in Storage for the

Weighing Lysimeters in $2006 .$. 


\section{List of Figures and Table}

Figure 32 Monthly Precipitation, E, and ET Measured in Weighing Lysimeters

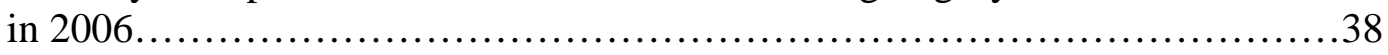

Figure 33 Soil Water Content in Pit 5 Flooring Using Automated TDR System..............38

Figure 34 Soil Water Content in Pit 3 Waste Cover (North Site) Using an Automated TDR System................................................. 40

Figure 35 Soil Water Content in Pit 3 Waste Cover (South Site) Using an Automated TDR System................................................... 40

Figure 36 Soil Water Content in Pit 4 Waste Cover Using an Automated TDR System............................................................ 41

Figure 37 Soil Water Content in Pit 5 Waste Cover Using an Automated TDR System............................................................. 41

Figure 38 Soil Water Content in U-3ax/bl Waste Cover (East Nest A) Using a TDR System.............................................................42

Figure 39 Soil Water Content in Bare Drainage Lysimeter (A) Using a TDR System........44

Figure 40 Soil Water Content Vegetated Drainage Lysimeter (E) Using TDR System.......44

Figure $41 \quad$ Soil Water Storage in Drainage Lysimeters.....................................45

Table 1 Area 3 Drainage Lysimeter Treatments in 2006.............................43 
This Page Intentionally Left Blank 


\section{ACRONYMS and ABBREVIATIONS}

\begin{tabular}{|c|c|}
\hline $\begin{array}{l}\text { AGL } \\
\text { AMSL } \\
\text { ARL/SORD }\end{array}$ & $\begin{array}{l}\text { above ground level } \\
\text { above mean sea level } \\
\text { Air Resources Laboratory, Special Operations and Research Division }\end{array}$ \\
\hline BJY & Buster-Jangle Y \\
\hline $\mathrm{BN}$ & Bechtel Nevada \\
\hline${ }^{\circ} \mathrm{C}$ & degrees Celsius \\
\hline CAU & Corrective Action Unit \\
\hline CFR & Code of Federal Regulations \\
\hline $\mathrm{Ci}$ & Curie \\
\hline $\mathrm{cm}$ & centimeter(s) \\
\hline DCG & Derived Concentration Guide \\
\hline DOE & U.S. Department of Energy \\
\hline $\mathrm{E}$ & evaporation \\
\hline EPA & U.S. Environmental Protection Agency \\
\hline ET & evapotranspiration; evapotranspirative \\
\hline $\begin{array}{l}{ }^{\circ} \mathrm{F} \\
\mathrm{ft}\end{array}$ & $\begin{array}{l}\text { degrees Fahrenheit } \\
\text { feet; foot }\end{array}$ \\
\hline GCD & Greater Confinement Disposal \\
\hline in. & inch(es) \\
\hline $\mathrm{km}$ & kilometer(s) \\
\hline LLW & low-level waste \\
\hline $\mathrm{m}$ & meter(s) \\
\hline MEDA & Meteorological Data Acquisition \\
\hline $\mathrm{mi}$ & mile(s) \\
\hline $\mathrm{mm}$ & millimeter(s) \\
\hline mph & mile(s) per hour \\
\hline $\mathrm{mrem} / \mathrm{yr}$ & millirem per year \\
\hline $\mathrm{m} / \mathrm{s}$ & meter(s) per second(s) \\
\hline $\mathrm{m}^{3}$ & cubic meters \\
\hline
\end{tabular}




\section{ACRONYMS and ABBREVIATIONS}

NTS Nevada Test Site

NSTec National Security Technologies, LLC

PA Performance Assessment

PET potential evapotranspiration

REECo Reynolds Electrical \& Engineering Co., Inc.

RREMP Routine Radiological Environmental Monitoring Plan

RWMS Radioactive Waste Management Site

SC specific conductance

TDR time-domain reflectometry

TLD thermoluminescent dosimeter

TOC total organic carbon

TOX total organic halides

VWC volumetric water content 


\section{INTRODUCTION}

This document summarizes the calendar year 2006 waste management environmental monitoring data for the Area 3 and Area 5 Radioactive Waste Management Sites (RWMSs). The Integrated Closure and Monitoring Plan for the Area 3 and Area 5 Radioactive Waste Management Sites at the Nevada Test Site (Bechtel Nevada [BN], 2005) describes details of the RWMS monitoring program. This report summarizes environmental data monitored for various media, as briefly defined below.

- Direct radiation monitoring - conducted to confirm that RWMS activities do not result in significant exposure above background levels.

- Air monitoring - conducted to confirm that RWMS activities do not result in significant radionuclide concentrations above background levels and confirm compliance with National Emission Standards for Hazardous Air Pollutants.

- Groundwater monitoring - conducted, as required by U.S. Environmental Protection Agency (EPA) regulations and U.S. Department of Energy (DOE) orders, to assess the water quality of the aquifer beneath the Area 5 RWMS, and confirm that Area 5 RWMS activities are not affecting the aquifer.

- Vadose zone monitoring - conducted to assess the water balance of the RWMSs, confirm the assumptions made in the Performance Assessments (PAs) (including no downward pathway), and evaluate the performance of operational monolayer-evapotranspirative (ET) waste covers.

- Soil-gas monitoring for tritium - conducted to evaluate tritium movement at waste containment cell GCD-05U.

- Biota monitoring for tritium - conducted to evaluate the upward pathway through the waste covers.

- Subsidence monitoring - conducted to ensure that subsidence features are repaired to prevent the development of preferential pathways through the covers.

These data are collected by BN and National Security Technologies, LLC (NSTec), as required by BN/DOE Contractual Work Smart Standards, which include various DOE orders and regulations from the Code of Federal Regulations (CFR). For a detailed description of these regulatory drivers, refer to the Integrated Closure and Monitoring Plan for the Area 3 and Area 5 Radioactive Waste Management Sites at the Nevada Test Site (BN, 2005). These regulatory drivers exist to mitigate risk to the public and environment and include: DOE Order 435.1 (Radioactive Waste Management), DOE Order 450.1 (Environmental Protection Program), DOE Order 5400.1 (General Environmental Protection Program), DOE Order 5400.5 (Radiation Protection of the Public and the Environment), Title 40 CFR 61 (EPA: National Emission Standards for Hazardous Air Pollutants), Title 40 CFR 264 (EPA: Standards for Owners and Operators of Hazardous Waste Treatment, Storage, and Disposal Facilities), and Title 40 CFR 265 (EPA: Interim Status Standards for Owners and Operators of Hazardous Waste Treatment, Storage, and Disposal Facilities). 
Environmental monitoring data are collected and analyzed as per Quality Assurance, Analysis, and Sampling Plans which can be found in the Nevada Test Site Routine Radiological Environmental Monitoring Plan (RREMP) (DOE, 2003). The RREMP was written with a Data Quality Objectives-driven process to identify what and how technically defensible environmental monitoring data are collected. 


\section{SITE DESCRIPTIONS}

\section{Area 3 RWMS}

The Area 3 RWMS is located on Yucca Flat within the Nevada Test Site (NTS). Yucca Flat is an elongated, sediment-filled basin that trends roughly north-south; the long axis extends approximately 27 kilometers $(\mathrm{km})(17$ miles [mi]), and the short axis approximately $16 \mathrm{~km}$ (10 mi). Yucca Flat is bound by Quartzite Ridge and Rainier Mesa on the north, the Halfpint Range on the east, the Massachusetts Mountains and CP Hills on the south, and Mine Mountain and the Eleana Range on the west (Figure 1). The Yucca Flat basin slopes from the north at an elevation of approximately 1,402 meters (m) (4,600 feet [ft]) above mean sea level (AMSL) to the south toward Yucca playa, with the lowest part of the basin at an elevation of approximately 1,189 $\mathrm{m}$ (3,900 ft) AMSL. The Area 3 RWMS elevation is 1,223 m (4,012 ft). Yucca Flat was one of several primary underground nuclear test areas and most of the length of the valley is marked with subsidence craters.

The thickness of the unsaturated zone at the Area 3 RWMS is estimated to be $488 \mathrm{~m}(1,600 \mathrm{ft})$, and the water table is assumed to occur in Tertiary tuff, based on data from surrounding boreholes. The tuff-alluvium contact is estimated to occur at a depth of between 305 and $457 \mathrm{~m}$ (1,000 and 1,500 ft) below land surface (BN, 1996).

Daily air temperatures can vary from -18 degrees Celsius $\left({ }^{\circ} \mathrm{C}\right)(0$ degrees Fahrenheit $[\mathrm{F}])$ to $24^{\circ} \mathrm{C}$ $\left(75^{\circ} \mathrm{F}\right)$ in winter and from $16^{\circ} \mathrm{C}\left(60^{\circ} \mathrm{F}\right)$ to $42^{\circ} \mathrm{C}\left(108^{\circ} \mathrm{F}\right)$ in summer. During 2006, the temperature range was $-13.7^{\circ} \mathrm{C}\left(7.34^{\circ} \mathrm{F}\right)$ to $40.0^{\circ} \mathrm{C}\left(104^{\circ} \mathrm{F}\right)$. The climate of Yucca Flat is arid. The average annual precipitation based on a 45-year record (1961 to 2006) at a location $4.5 \mathrm{~km}$ (2.8 mi) northwest of the Area 3 RWMS is 164.1 millimeter (mm) (6.46 inches [in.]) (Air Resources Laboratory [ARL], 2007). The average annual precipitation based on the 11-year record (1996 to 2006) collected at the Area 3 RWMS is $160.1 \mathrm{~mm}$ (6.30 in.). There was $87.2 \mathrm{~mm}$ (3.43 in.) of precipitation at the Area 3 RWMS in 2007. Precipitation is highly variable at the Area 3 RWMS. The standard deviation of the 11-year record of annual precipitation is $95.7 \mathrm{~mm}$ (3.77 in.); the maximum annual precipitation was $374.1 \mathrm{~mm}$ (14.73 in.) in 1998 and the minimum was $26.2 \mathrm{~mm}$ (1.03 in.) in 2002. Average annual potential evapotranspiration (PET) at the Area 3 RWMS, calculated using local meteorology data, is approximately ten times the annual average precipitation (Desotell et al., 2006).

\section{Area 5 RWMS}

The Area 5 RWMS is located on northern Frenchman Flat at the juncture of three coalescing alluvial fan piedmonts (Snyder et al., 1995). Frenchman Flat is a closed intermontane basin located in the southeastern portion of the NTS. Frenchman Flat is bound by the Massachusetts Mountains and the Halfpint Range on the north, the Buried Hills on the east, the Spotted Range on the south, and the Wahmonie Volcanic Center on the west (see Figure 1). The valley floor slopes gently toward a central playa. Ground surface elevations range from $938 \mathrm{~m}(3,077 \mathrm{ft}$ ) AMSL at the playa to over $1,220 \mathrm{~m}(4,003 \mathrm{ft})$ AMSL in the nearby surrounding mountains. The Area 5 RWMS elevation is $962 \mathrm{~m}(3,156 \mathrm{ft})$. 


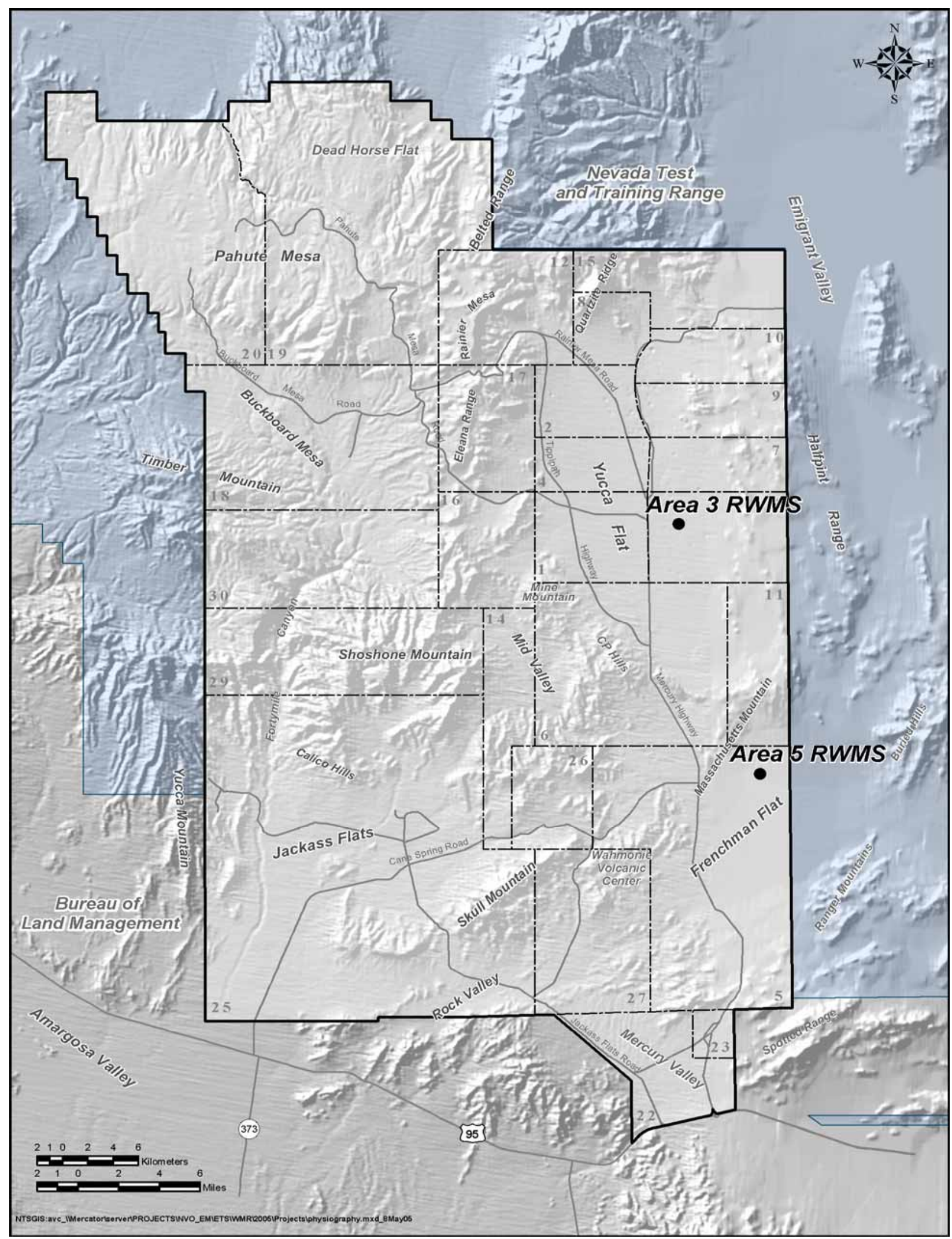

Figure 1

Location of the Area 3 and Area 5 RWMSs on the NTS 
The thickness of the unsaturated zone at the Area $5 \mathrm{RWMS}$ is $235.8 \mathrm{~m}(774 \mathrm{ft})$ at the southeast corner of the RWMS (Well UE5PW-1), $256.6 \mathrm{~m}(842 \mathrm{ft}$ ) at the northeast corner (Well UE5PW-2), and $271.5 \mathrm{~m}$ (891 ft) to the northwest of the RWMS (Well UE5PW-3). Wells UE5PW-1 and UE5PW-2 penetrate only alluvium, while Well UE5PW-3 encounters Tertiary tuff at a depth of approximately 189 m (620 ft) (Reynolds Electrical \& Engineering Co., Inc. [REECo], 1994). The water table beneath the Area 5 RWMS is extremely flat. The average groundwater elevation measured at these wells is $733.7 \mathrm{~m}(2,407 \mathrm{ft})$ AMSL.

Air temperatures can vary from $-15^{\circ} \mathrm{C}\left(5^{\circ} \mathrm{F}\right)$ to $24^{\circ} \mathrm{C}\left(75^{\circ} \mathrm{F}\right)$ in winter and from $16^{\circ} \mathrm{C}\left(60^{\circ} \mathrm{F}\right)$ to $45^{\circ} \mathrm{C}\left(113^{\circ} \mathrm{F}\right)$ in summer. During 2006 , the temperature range was $-10.7^{\circ} \mathrm{C}\left(12.7^{\circ} \mathrm{F}\right)$ to $43.2^{\circ} \mathrm{C}$ $\left(110^{\circ} \mathrm{F}\right)$. The climate of Frenchman Flat is arid. The average annual precipitation based on a 44-year record (1963 to 2006) at a location $6.4 \mathrm{~km} \mathrm{(4} \mathrm{mi)} \mathrm{south} \mathrm{of} \mathrm{the} \mathrm{Area} 5$ RWMS is $124.9 \mathrm{~mm}$ (4.92 in.) (ARL, 2006). The average annual precipitation based on the 12-year record (1995 to 2006) collected at the Area 5 RWMS is $131.3 \mathrm{~mm}$ (5.17 in.). There was $80.7 \mathrm{~mm}$ (3.18 in.) of precipitation at the Area 3 RWMS in 2006. Precipitation is highly variable at the Area 5 RWMS. The standard deviation of the 12-year record of annual precipitation is $64.0 \mathrm{~mm}$ (2.52 in.); the maximum annual precipitation was $258.9 \mathrm{~mm}$ (10.19 in.) in 1998 and the minimum was $37.7 \mathrm{~mm}$ (1.48 in.) in 2002. Average annual PET at the Area 5 RWMS, calculated using local meteorology data, is approximately 13 times the annual average precipitation (Desotell et al., 2006).

Areas 3 and 5 are similar, except for slight differences in air temperature, precipitation, and soil texture. Area 3 receives approximately 20 percent more rainfall than Area 5, the annual average temperature at Area 3 is about $2^{\circ} \mathrm{C}\left(4^{\circ} \mathrm{F}\right)$ cooler than at Area 5, and soils at Area 3 are generally finer grained than at Area 5.

\section{Hydrologic Conceptual Model of the Area 3 and Area 5 RWMSs}

Climate and vegetation strongly control the water movement in the upper few meters of alluvium at both RWMSs. The magnitude and direction of both liquid and vapor fluxes vary seasonally and often daily. Except for periods following precipitation events, water contents in the nearsurface are quite low. Below the dynamic near-surface is a region where relatively steady upward water movement is occurring. In this region of slow upward flow, stable isotope compositions of soil pore water confirm that evaporation (E) is the dominant process (Tyler et al., 1996). The upward flow region extends to depths from approximately 3 to $49 \mathrm{~m}$ (10 to $160 \mathrm{ft}$ ) in Area 3, and from approximately 3 to $40 \mathrm{~m}$ (10 to $131 \mathrm{ft})$ in Area 5. Below the upward flow region, water potential measurements indicate the existence of a static region. The static region begins between approximately 49 to $119 \mathrm{~m}$ (160 to $390 \mathrm{ft})$ in Area 3, and between approximately 40 to $90 \mathrm{~m}$ (131 to $295 \mathrm{ft}$ ) in Area 5 (Shott et al., 1997, 1998). In the static region, essentially no vertical liquid flow is currently occurring. Below the static region, flow is steady and downward due to gravity (Figure 2). Stable isotope compositions of pore water from these depths indicate that infiltration into this zone occurred under cooler past climatic conditions (Tyler et al., 1996). If water were to migrate below the current static zones, movement to the groundwater would be extremely slow due to the low water content of the alluvium. Estimates of travel time to the groundwater (assuming zero upward flux), based on 


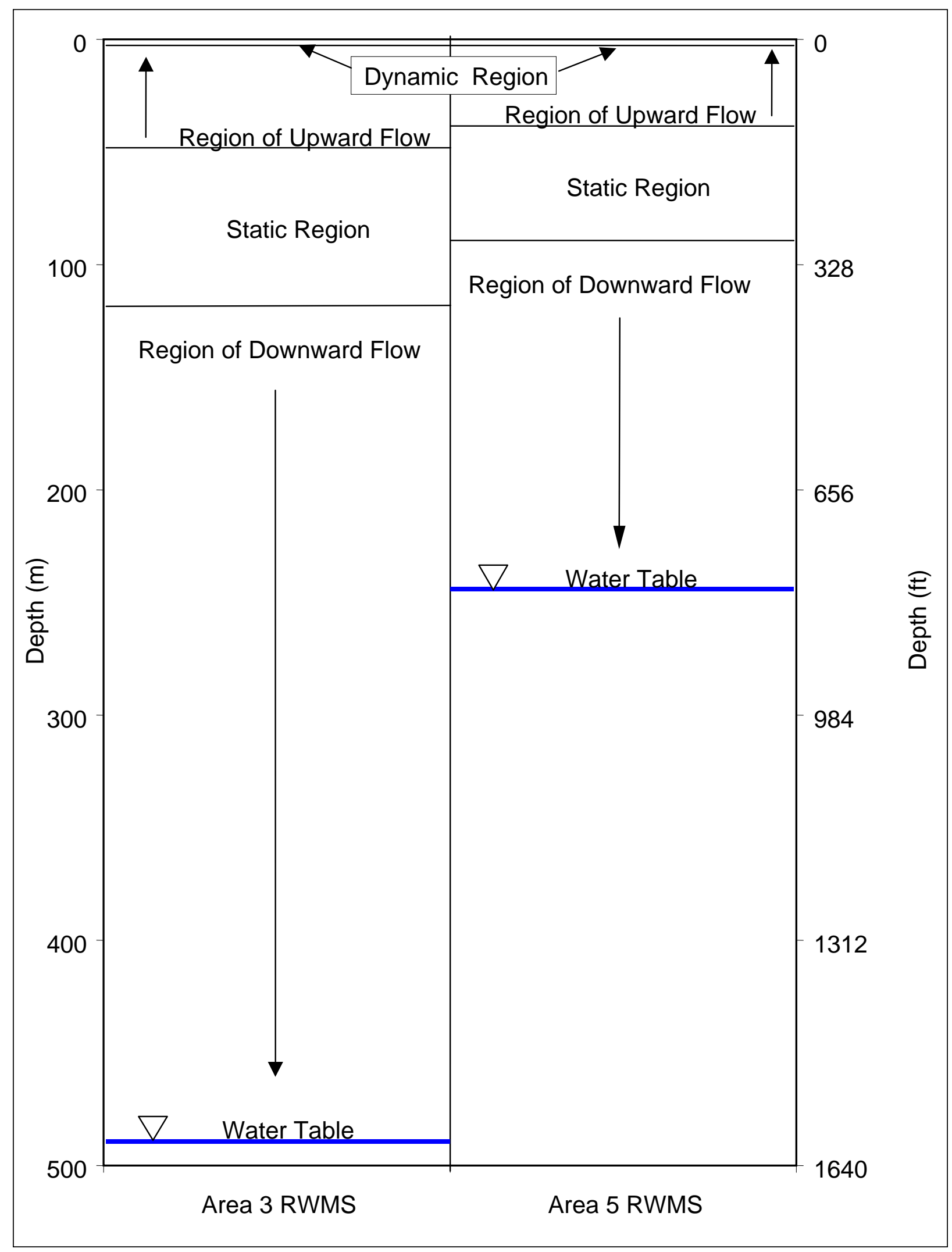

Figure 2

Vadose Zone Hydrologic Conceptual Models of the Area 3 and Area 5 RWMSs 
hydraulic characteristics of the alluvium and assuming that current conditions would still apply, are in excess of 500,000 years in Area 3 (Levitt and Yucel, 2002) and 50,000 years in Area 5 (Shott et al., 1998).

Based on the results of extensive research, field studies, modeling efforts, and monitoring data which are summarized in the Area 3 and Area 5 Performance Assessments (PAs) (Shott et al., 1997, 1998; Levitt et al., 1999; Levitt and Yucel, 2002; Desotell et al., 2006), groundwater recharge is not occurring under current climatic conditions at the RWMSs. Studies indicate that under bare-soil conditions, such as those found at the operational waste cell covers, some drainage may eventually occur through the waste covers into the waste zone. This drainage is estimated to be about 8 percent of the annual rainfall at Area 5, based on one-dimensional modeling results (Desotell et al., 2006). In addition, monitoring data from a bare-soil weighing lysimeter located in Area 5 indicate that the soil water storage has increased slowly with time and water is beginning to accumulate at the bottom of the lysimeter. 


\section{This Page Intentionally Left Blank}




\section{PROJECT DESCRIPTION}

The Area 3 and Area 5 RWMSs are designed and operated for the disposal of low-level radioactive waste (LLW) and mixed waste that is generated on site (at the NTS), LLW from DOE off-site locations, and LLW from other approved off-site generators.

\section{Area 3 RWMS}

Waste disposal cells within the Area 3 RWMS are subsidence craters resulting from underground nuclear testing. The seven craters within the Area 3 RWMS ranged from 122 to $177 \mathrm{~m}$ (400 to $580 \mathrm{ft}$ ) in diameter and from 14 to $32 \mathrm{~m}$ (46 to $105 \mathrm{ft}$ ) in depth at the time of formation (Plannerer, 1996). Disposal in the U-3ax crater began in the late 1960s; disposal began in U-3bl in 1984. Waste forms consisted primarily of contaminated soil and scrap metal, with some construction debris, equipment, and containerized waste. Craters U-3ax and U-3bl were combined to form the U-3ax/bl disposal unit (Corrective Action Unit [CAU] 110), which is now

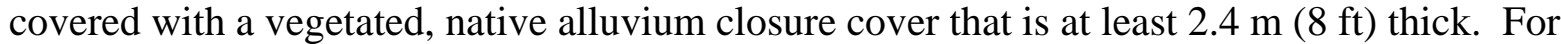
details of the final closure plan of CAU 110, refer to BN (2001a). Disposal in the combined unit U-3ah/at began in 1988. Disposal cell U-3ah/at has been used for disposal of bulk LLW from the NTS and approved off-site generators. Crater U-3bh was originally used for disposal of contaminated soils from the Tonopah Test Range in 1997 and has been used for waste disposal from other approved generators. The remaining two craters are not in use (Figure 3). For a detailed description of the facilities at the Area 3 RWMS, refer to Shott et al. (1997).

\section{Area 5 RWMS}

Waste disposal has occurred at the Area 5 RWMS since the early 1960s. The Area 5 RWMS consists of 32 landfill cells (pits and trenches) and 13 greater confinement disposal (GCD) boreholes (Figure 4). Some previous documents list fewer landfill cells, but new cells continue to be constructed and Trench 4 was separated into T04C and T04C-1 (BN, 2005). Pits and trenches range in depth from 4.6 to $15-\mathrm{m}$ (15 to 48-ft). The unlined disposal units receive sealed waste containers. Containers are stacked to approximately $1.2 \mathrm{~m}(4-\mathrm{ft})$ below original grade and

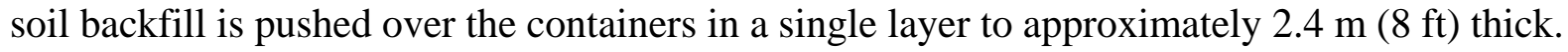
For a detailed description of the facilities at the Area 5 RWMS, refer to Shott et al. (1998). For further descriptions of pits, trenches, and GCD boreholes, refer to BN (2005) and Cochran et al. (2001).

There are currently eight pits receiving waste at the Area 5 RWMS. The open pits include P03U, P06U, P09U, P12C, P13U, P14U, P15U, and P16C. The only active mixed waste disposal cell is P03U. All other active units contain LLW except P06U, which contains asbestiform LLW. Landfill cells that have been closed to date include all 16 trenches and 8 pits. The eight closed pits are P01U, P02U, P04U, P05U, P07U, P08U, P10C, and P11U. 


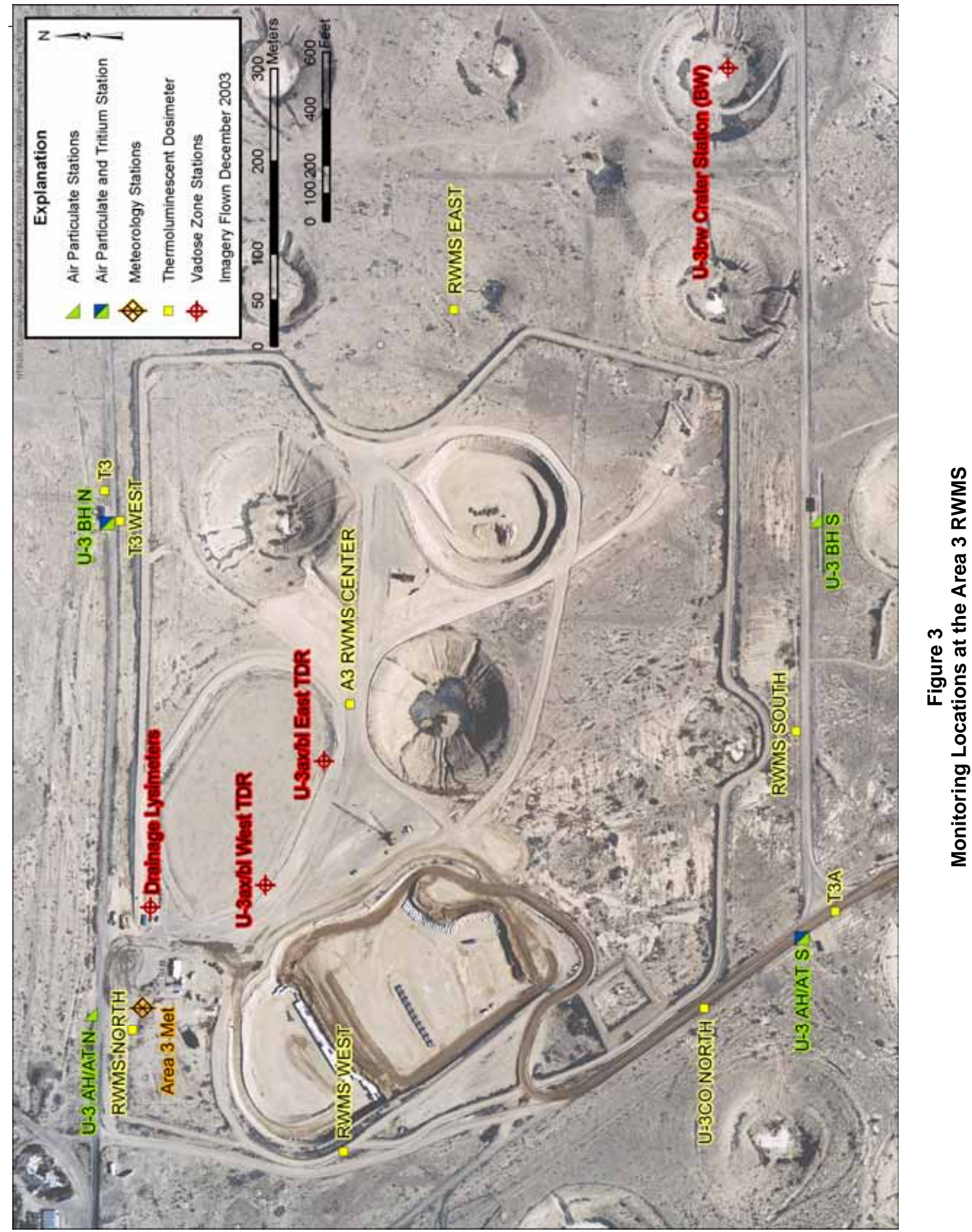




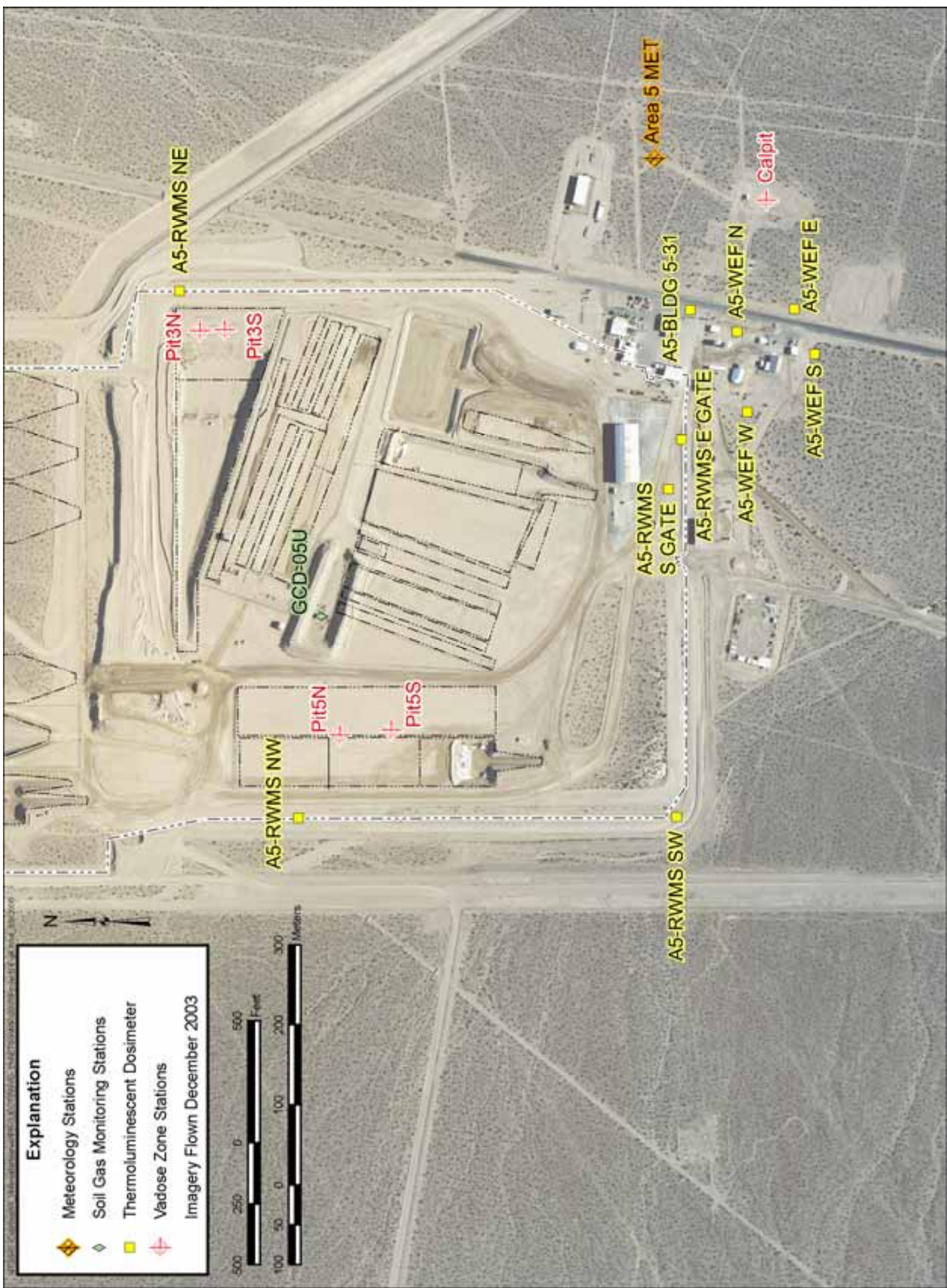

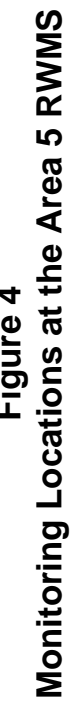




\section{This Page Intentionally Left Blank}




\section{ENVIRONMENTAL MONITORING DATA}

\section{Types of RWMS Environmental Data}

Area 3 RWMS monitoring locations are shown in Figure 3, and Area 5 RWMS monitoring locations are shown in Figures 4 and 5. This report provides a general description and graphical representations of some of these data. Monitoring data currently being collected include:

\section{Radiation Exposure Data}

- Quarterly thermoluminescent dosimeter (TLD) measurements

\section{Air Monitoring Data}

- Weekly Data

- alpha concentrations

- beta concentrations

- Biweekly Data

- tritium concentrations

- Monthly Data

- gamma concentrations

- americium concentrations

- plutonium concentrations

- Periodic radon flux measurements from waste covers

\section{Groundwater Monitoring Data}

- Quarterly Water-Level Measurements (manual)

- Semiannual Indicators of Contamination

- pH (field measurement)

- Specific conductance (SC) (field measurement)

- Total organic carbon (TOC)

- Total organic halides (TOX)

- Tritium

- Semiannual General Water Chemistry Parameters

- Total calcium, iron, magnesium, manganese, potassium, sodium, silicon

- Total sulfate, chloride, fluoride

- Alkalinity

- Biennial RREMP Analyses

- Gross alpha

- Gross beta

- Gamma spectroscopy

- Plutonium as ${ }^{238} \mathrm{Pu}$ and ${ }^{239+240} \mathrm{Pu}$

\section{Meteorology Monitoring Data}

- Daily Meteorology Data

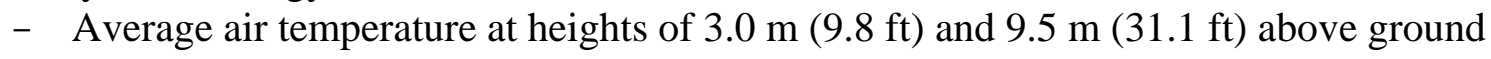
level (AGL)

- $\quad$ Maximum air temperature at heights of $3.0 \mathrm{~m}(9.8 \mathrm{ft})$ and $9.5 \mathrm{~m}$ (31.1 ft) AGL 


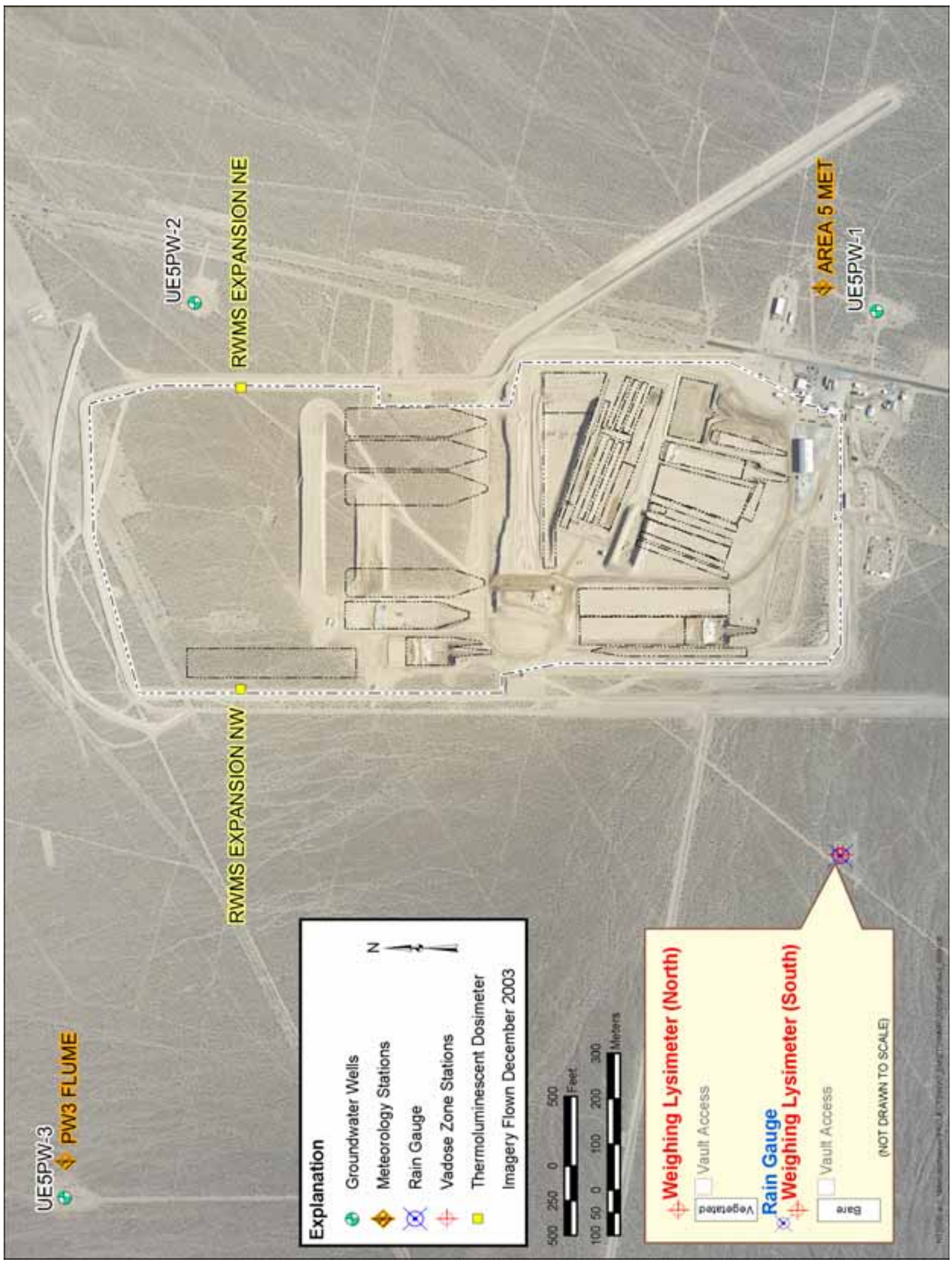

告 
- $\quad$ Minimum air temperature at heights of $3.0 \mathrm{~m}(9.8 \mathrm{ft})$ and $9.5 \mathrm{~m}(31.1 \mathrm{ft})$ AGL

- Average relative humidity at heights of $3.0 \mathrm{~m}(9.8 \mathrm{ft})$ and $9.5 \mathrm{~m}(31.1 \mathrm{ft})$ AGL

- Maximum relative humidity at heights of $3.0 \mathrm{~m}(9.8 \mathrm{ft})$ and $9.5 \mathrm{~m}(31.1 \mathrm{ft})$ AGL

- Minimum relative humidity at heights of $3.0 \mathrm{~m}(9.8 \mathrm{ft})$ and $9.5 \mathrm{~m}(31.1 \mathrm{ft})$ AGL

- $\quad$ Average wind speed at heights of $3.0 \mathrm{~m}(9.8 \mathrm{ft})$ and $9.5 \mathrm{~m}(31.1 \mathrm{ft})$ AGL

- $\quad$ Maximum wind speed at heights of $3.0 \mathrm{~m}$ (9.8 ft) and $9.5 \mathrm{~m}$ (31.1 ft) AGL

- Average barometric pressure

- Maximum barometric pressure

- Minimum barometric pressure

- Total precipitation

- Hourly Meteorology Data

- Average air temperature at heights of $3.0 \mathrm{~m}(9.8 \mathrm{ft})$ and $9.5 \mathrm{~m}(31.1 \mathrm{ft}) \mathrm{AGL}$

- Average relative humidity at heights of $3.0 \mathrm{~m}$ (9.8 ft) and 9.5 m (31.1 ft) AGL

- $\quad$ Average wind speed at heights of $3.0 \mathrm{~m}(9.8 \mathrm{ft})$ and $9.5 \mathrm{~m}(31.1 \mathrm{ft})$ AGL

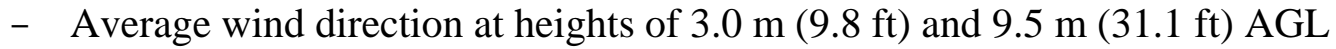

- Average barometric pressure

- Average solar radiation

- Total precipitation

\section{Vadose Zone Monitoring Data}

- Annual Soil Gas Monitoring Data (soil gas tritium concentrations measured at GCD-05U gas sampling ports [nine depths])

- Daily Weighing Lysimeter Data (Area 5)

- Daily E from the bare-soil weighing lysimeter

- Daily ET from the vegetated weighing lysimeter

- Daily Drainage Lysimeter Data (Area 3)

- Soil volumetric water content (VWC), soil matric potential, and temperature with depth

- Total soil water storage

- Daily Automated Vadose Zone Monitoring System Data

- Soil VWC with depth in waste covers

- Soil VWC beneath waste cells

- Soil matric potential with depth in waste covers

- Soil temperature with depth in waste covers

- Soil temperature beneath waste cells

- Periodic Subsidence Monitoring Data (locations and description of subsidence features on waste covers)

- Biota Monitoring Data (periodic analysis of plant and animal samples for tritium concentrations) 


\section{Radiation Exposure Data}

The goals of direct radiation monitoring are to assess the state of the external radiation environment, detect changes in that environment, and measure gamma radiation levels near potential exposure sites. Performance objectives in DOE Order 435.1 state that LLW disposal facilities shall be sited, designed, operated, maintained, and closed so it is reasonable to expect that the total effective dose equivalent from all exposure pathways, except the dose from radon, to representative members of the public shall not exceed 25 millirem/year (mrem/yr). Because the RWMSs are located well within the NTS boundaries, no members of the public have access to these areas for significant periods of time. However, exposure rates measured by TLDs located at the RWMSs show the potential dose to a hypothetical person residing year-round at the RWMS.

TLDs were used to measure ionizing radiation exposure from all sources, including natural and man-made radioactivity. The TLD used was the Panasonic UD 814AS, consisting of four elements housed in an air-tight, water-tight, ultraviolet-light-protected case. A slightly shielded lithium borate element was used to check low-energy radiation levels and an average of three calcium sulfate elements were used to measure penetrating gamma radiation.

Figures 3, 4, and 5 show TLD monitoring locations. At each location, a pair of TLDs were placed at $1 \pm 0.3 \mathrm{~m}$ (28 to $51 \mathrm{in}$.) AGL and were exchanged for analysis on a quarterly basis. TLDs were analyzed quarterly using automated TLD readers that were calibrated and maintained by the BN Radiological Control Department. Reference TLDs were exposed to 100 milliroentgen from a ${ }^{137} \mathrm{Cs}$ radiation source under controlled conditions and were analyzed along with TLDs collected from the environment to scale their response.

Between 1952 and 1972, 60 nuclear weapons tests were conducted within $400 \mathrm{~m}(1,312 \mathrm{ft})$ of the Area 3 RWMS boundary. Fourteen of these tests were atmospheric tests which left radionuclidecontaminated surface soil and, therefore, elevated radiation exposures across the area. Waste pits in the Area 3 RWMS are subsidence craters from seven subsurface tests that are being filled with LLW. During disposal operations, the waste is covered with clean soil resulting in lower exposures inside the Area 3 RWMS, compared with the average exposures at the fence line or in Area 3 outside the fence line.

Annual radiation exposures during 2006 at locations inside and near the Area 3 RWMS are shown in Figure 6. The monitoring locations are RWMS Center, RWMS North, RWMS East, RWMS South, RWMS West, T3, T3 West, T3A, and U 3CO North (see Figure 3). The exposures measured inside the Area 3 RWMS and three of four measurements at the boundary were within the range of background exposures. The TLD locations outside the Area 3 RWMS boundary and RWMS South have higher exposures. The locations with higher exposures are associated with historic aboveground nuclear weapon test locations. Given this, current Area 3 RWMS operations have contributed negligible external exposure to a hypothetical person residing at the Area 3 RWMS boundary during 2006.

Twenty-five nuclear weapons tests were conducted within $6.3 \mathrm{~km}$ (3.9 mi) of the Area 5 RWMS between 1951 and 1971. Fifteen of these were atmospheric tests and nine of the remaining tests released radioactivity to the surface, which contributes to exposures in the area. No nuclear 
Area 3 RWMS Estimated Annual Exposures

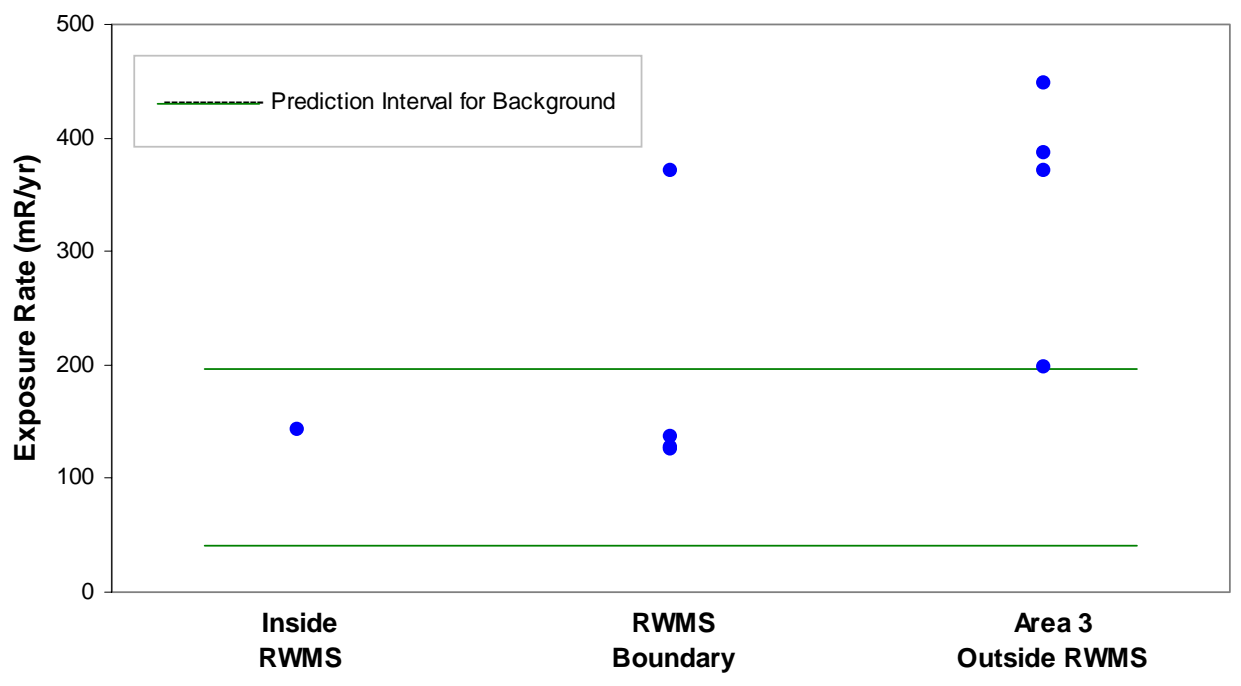

Figure 6

Annual Exposure Rates at the Area 3 RWMS during 2006

weapons testing occurred within the boundaries of the Area 5 RWMS. During 2006, estimated annual exposures from TLD measurements at the Area 5 RWMS were within the range of exposures measured at NTS background locations.

Comparisons of 1998 to 2006 direct radiation exposure data using TLDs from the two RWMSs and NTS background locations are presented in Figures 7 and 8 . These data indicate that direct radiation exposure at the Area 3 and Area 5 RWMSs is low.

\section{Air Monitoring Data}

\section{Tritium}

Tritium is a highly mobile isotope of hydrogen that acts as a conservative tracer and is therefore an excellent performance indicator of volatile radionuclide migration from waste cells. Atmospheric moisture is collected at the Area 3 and Area 5 RWMSs and analyzed for tritium. Approximately 11 cubic meters $\left(\mathrm{m}^{3}\right.$ ) (388 cubic feet) of air is drawn across a desiccant during a two-week period to collect atmospheric moisture. The moisture is distilled from the desiccant and the tritium activity is measured by liquid scintillation.

The tritium monitoring locations at the Area 3 RWMS are U-3bh N and U-3ah/at S (see Figure 3). The Area 5 RWMS monitoring locations are DoD (approximately $1.0 \mathrm{~km}$ [0.6 mi] north of the Area 5 RWMS) and Sugar Bunker (approximately $1.5 \mathrm{~km}$ [0.9 mi] south of the Area 5 RWMS). These Area 5 monitoring locations are in the prevailing downwind directions from the RWMS and provide adequate environmental monitoring for the Area 5 RWMS. 


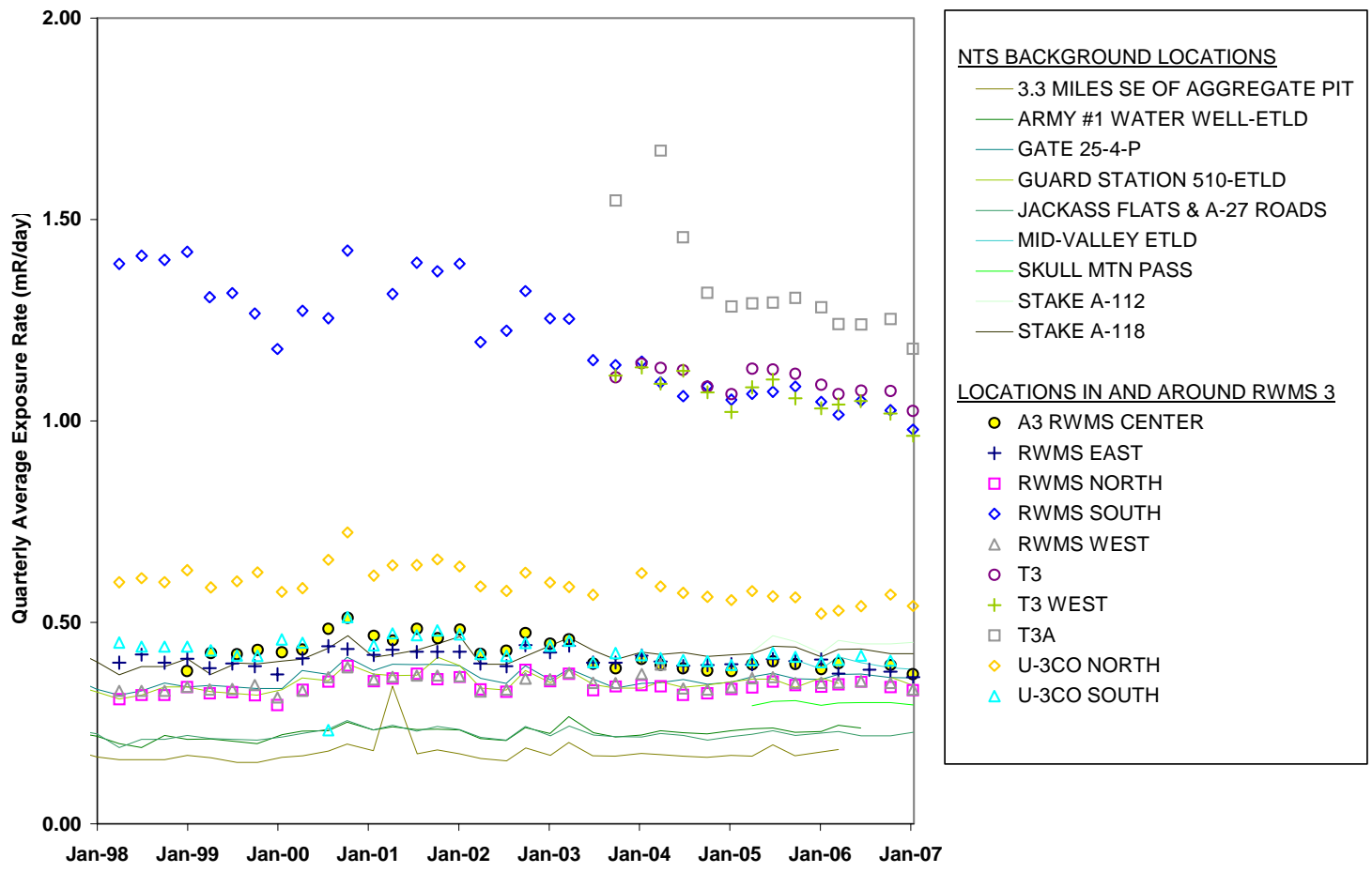

Figure 7

Quarterly Average Daily Exposure Rates at the Area 3 RWMS and NTS Background TLD Locations, 1998 to 2006

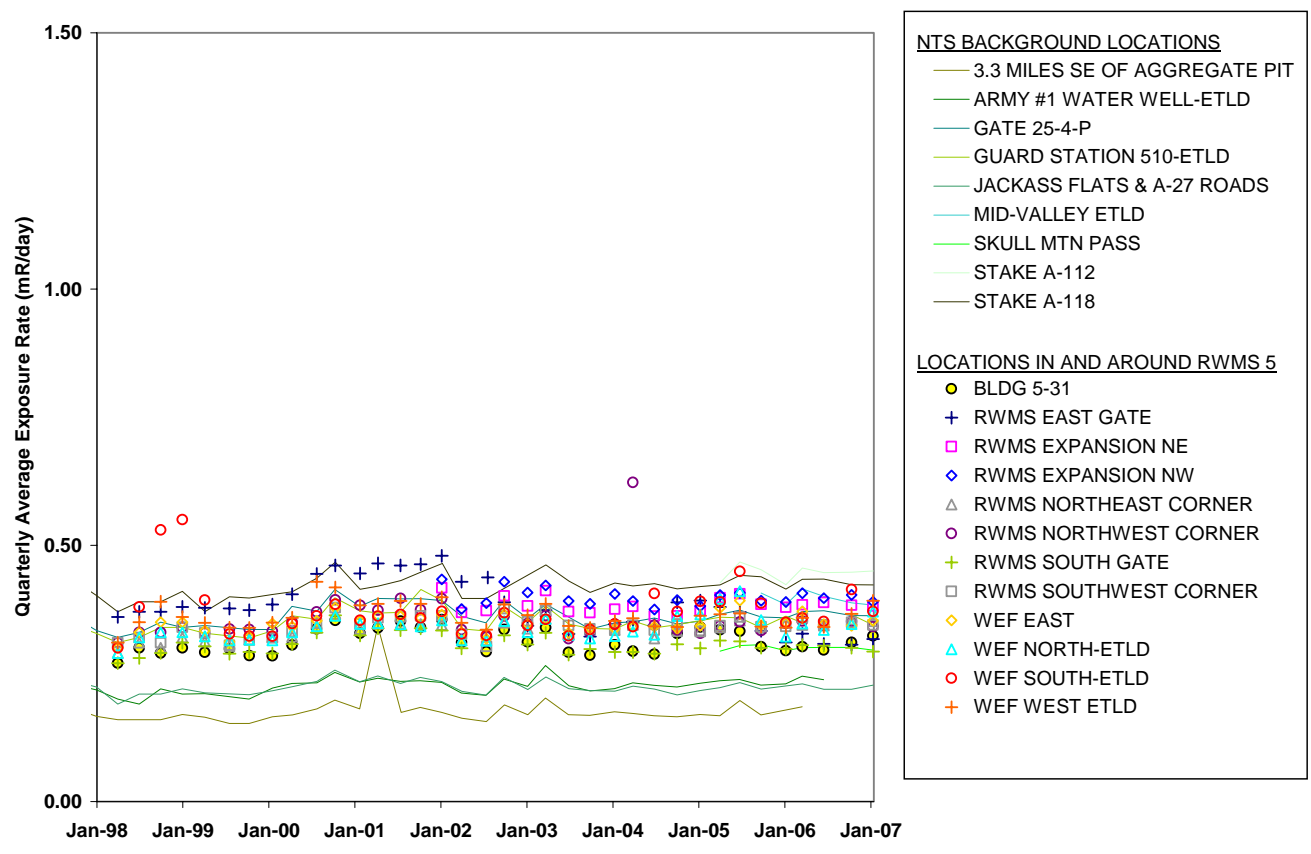

Figure 8

Quarterly Average Daily Exposure Rates at the Area 5 RWMS and NTS Background TLD Locations, 1998 to 2006 
Tritium concentrations at the Area 3 and Area 5 RWMSs are below the DOE Derived Concentration Guide (DCG) for tritium (Figure 9). The DCG is the concentration of a radionuclide in air that could be inhaled for one year and not exceed the DOE radiation standard of $100 \mathrm{mrem} / \mathrm{yr}$ committed effective dose equivalent to the public (DOE Order 5400.5).

The higher-than-normal tritium concentrations at DoD and Sugar Bunker during January through June are suspected of being from a Sealand ${ }^{\circledR}$ shipping container, which was being retrieved on December 19, 2005, and was found to be punctured. This container held 40 drums of tritiumladen waste. It is likely that the container was punctured when it was buried in April 2005 and tritium moved into the surrounding soil. This tritium in the soil is the likely source of elevated tritium measured through May 2006 because the container was patched shortly after the punctured container was discovered in December 2005.

\section{Particulates}

Air particulate samples are collected weekly on glass-fiber filters near each RWMS and are screened for gross alpha and gross beta radioactivity to provide early detection of any change in environmental concentrations of airborne radioactivity. Monthly composites of the filters from each sampling location are analyzed by gamma spectroscopy for gamma-emitting radioactivity and by radiochemical analyses for americium and plutonium.

The 2006 analysis results indicate that no man-made radioactivity was detected by gamma spectroscopy. However, concentrations of americium and plutonium near the minimum detectable concentrations of the measurements were detected (Figures 10, 11, and 12). The americium and plutonium concentrations at the Area 3 RWMS were slightly higher than at the Area 5 RWMS. Because of historical testing adjacent to the Area 3 RWMS, it is not possible to determine whether waste operations contributed to these measured concentrations. All measured concentrations of americium and plutonium were below the DCG for each radionuclide.

\section{Radon}

The performance objective (DOE Order 435.1) and regulatory limit (Title 40 CFR 61, Subpart Q) for radon emissions from DOE facilities is 20 picoCuries per square meter per second. Radon flux measurements were made during 2006 on the Area 3 and Area 5 RWMSs for comparison with the regulatory limit. Radon flux was measured on the U-ax/bl cover in Area 3 and on the P06U and P13U covers in Area 5. These covers were selected because they contain radon and thorium-bearing waste. Radon flux was also measured at an undisturbed site outside both the Area 3 and Area 5 RWMSs. Figure 13 shows the measurement locations in Area 3 and Figure 14 shows the measurement locations in Area 5. Measurements performed December 20 through 28, 2006, were made using radon flux domes (Rad Elec, Inc.) placed on the ground surface. Electrets inserted in the domes measure radon flux from the ground.

Radon flux results (2000 to 2006) are summarized in Figure 15. All radon flux measurements were at least four times lower than the regulatory limit. Some individual measurements on the U-3ax/bl cover were slightly higher than measurements made during the previous seven years, but the average value was not significantly different from that at the Area 3 control location (CC Road) $(\mathrm{P}=0.407)$. 


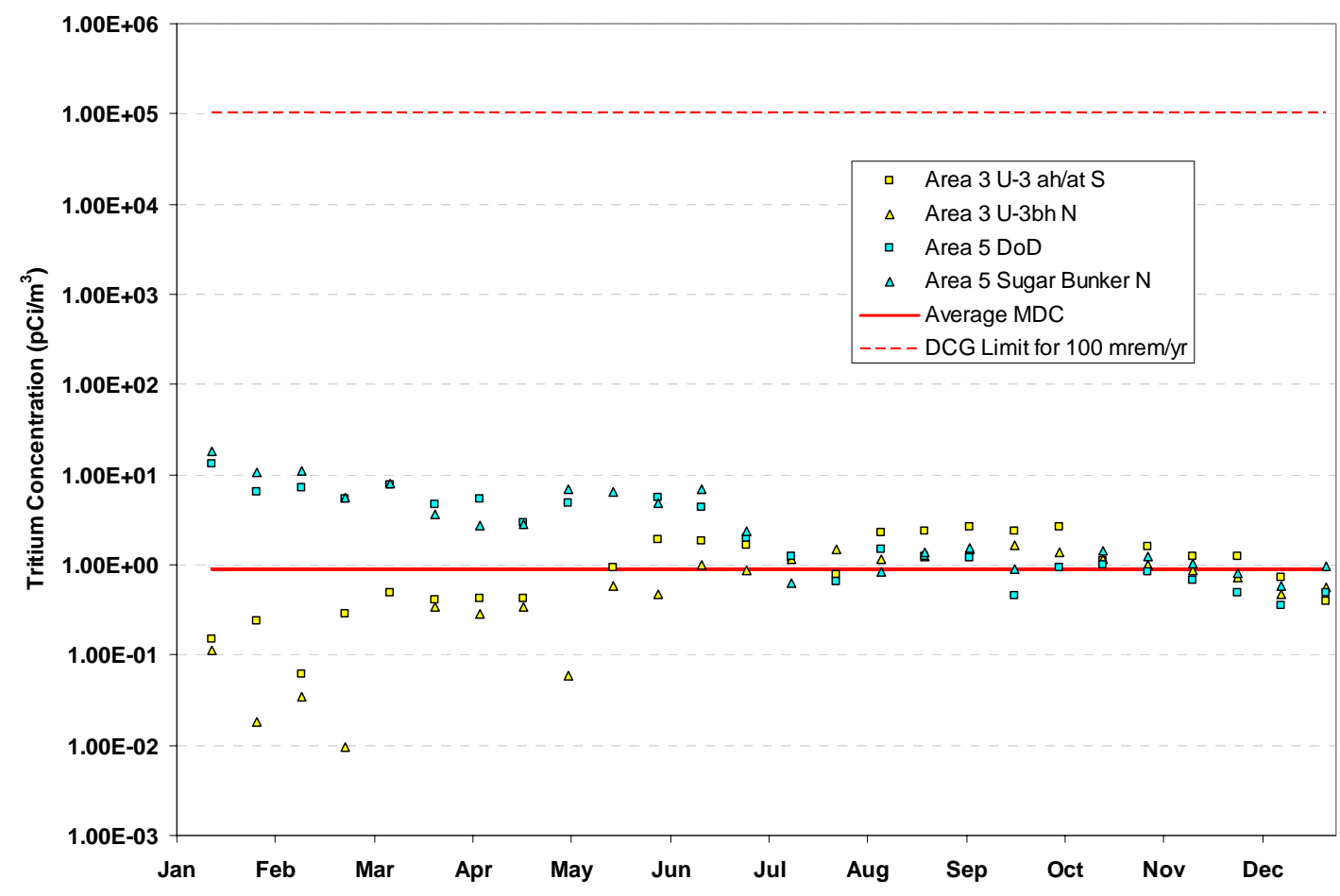

Figure 9

Tritium Concentration in Air

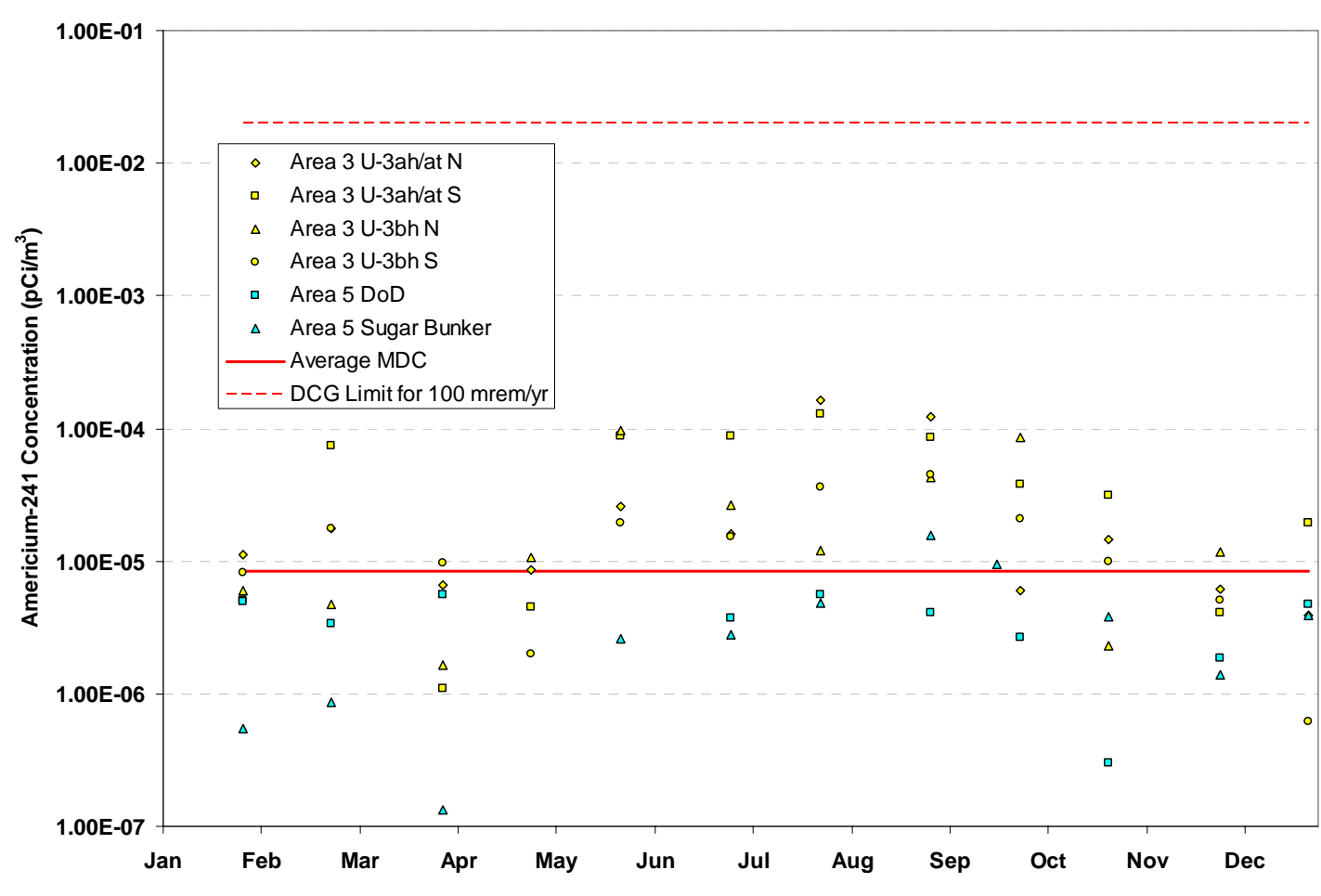

Figure 10

${ }^{241}$ Am Concentrations in Air at the RWMSs and Other Locations 


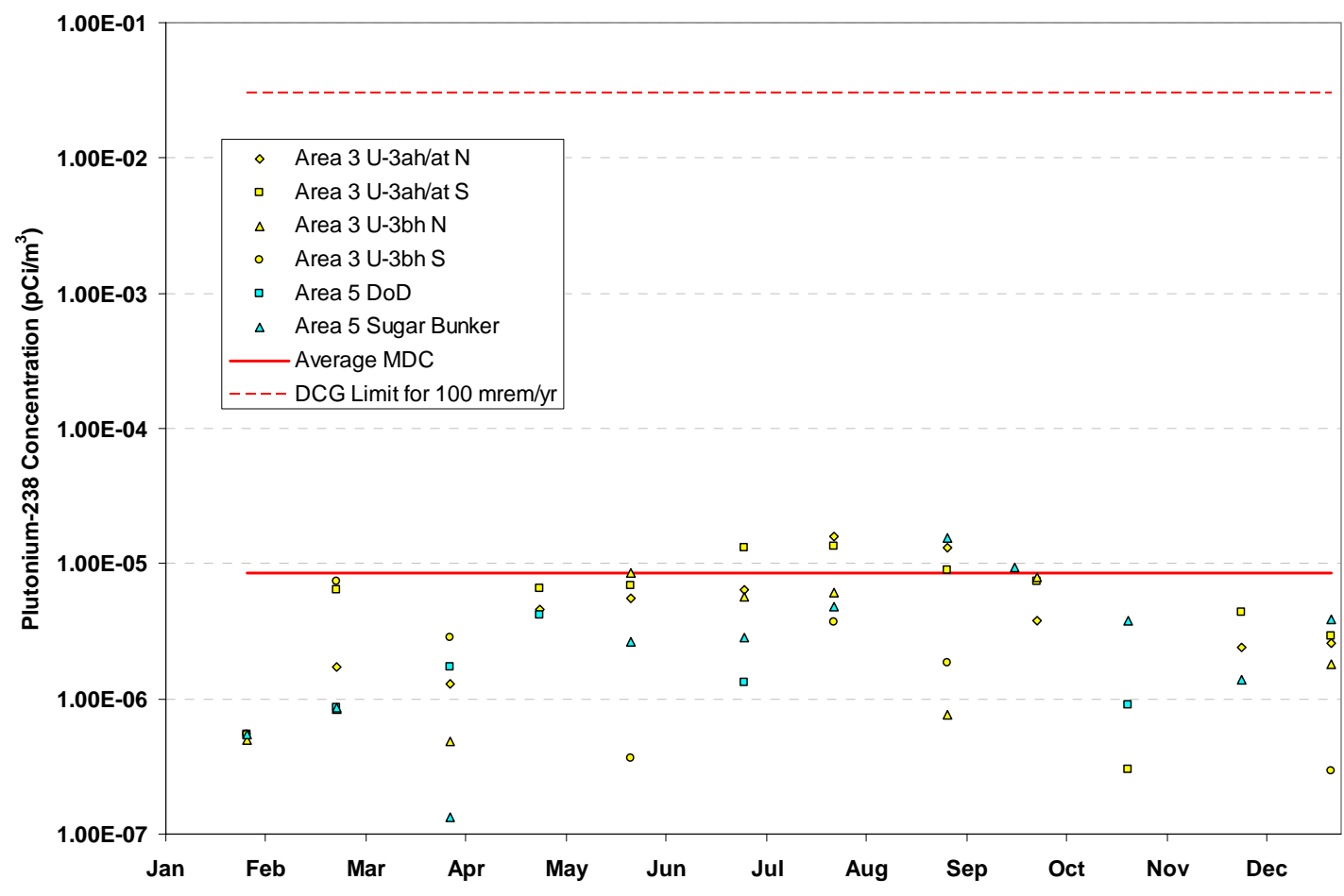

Figure 11

${ }^{238} \mathrm{Pu}$ Concentrations in Air at the RWMSs and Other Locations

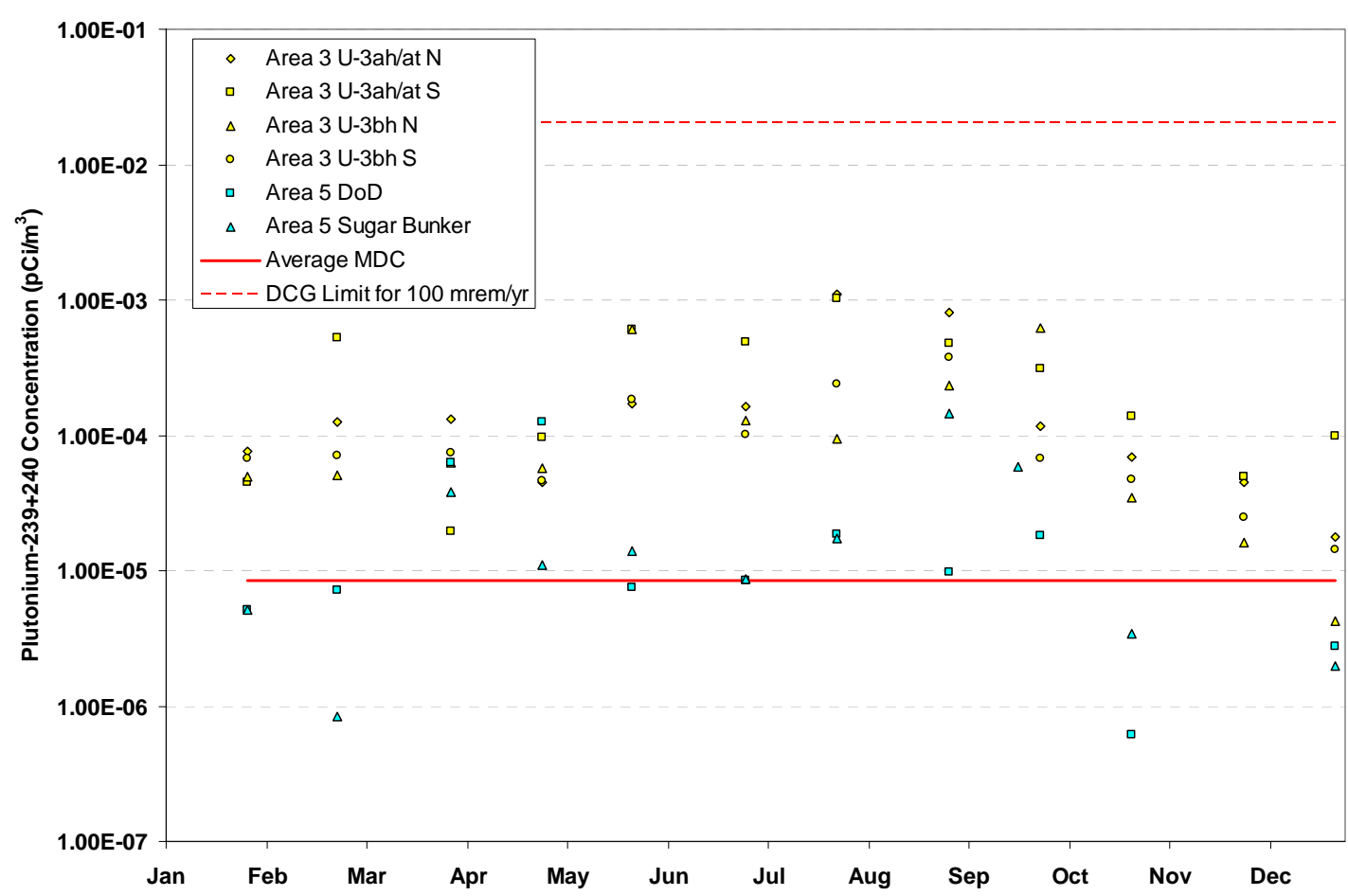

Figure 12

${ }^{239}$ Plutonium Concentrations in Air at the RWMSs and Other Locations 


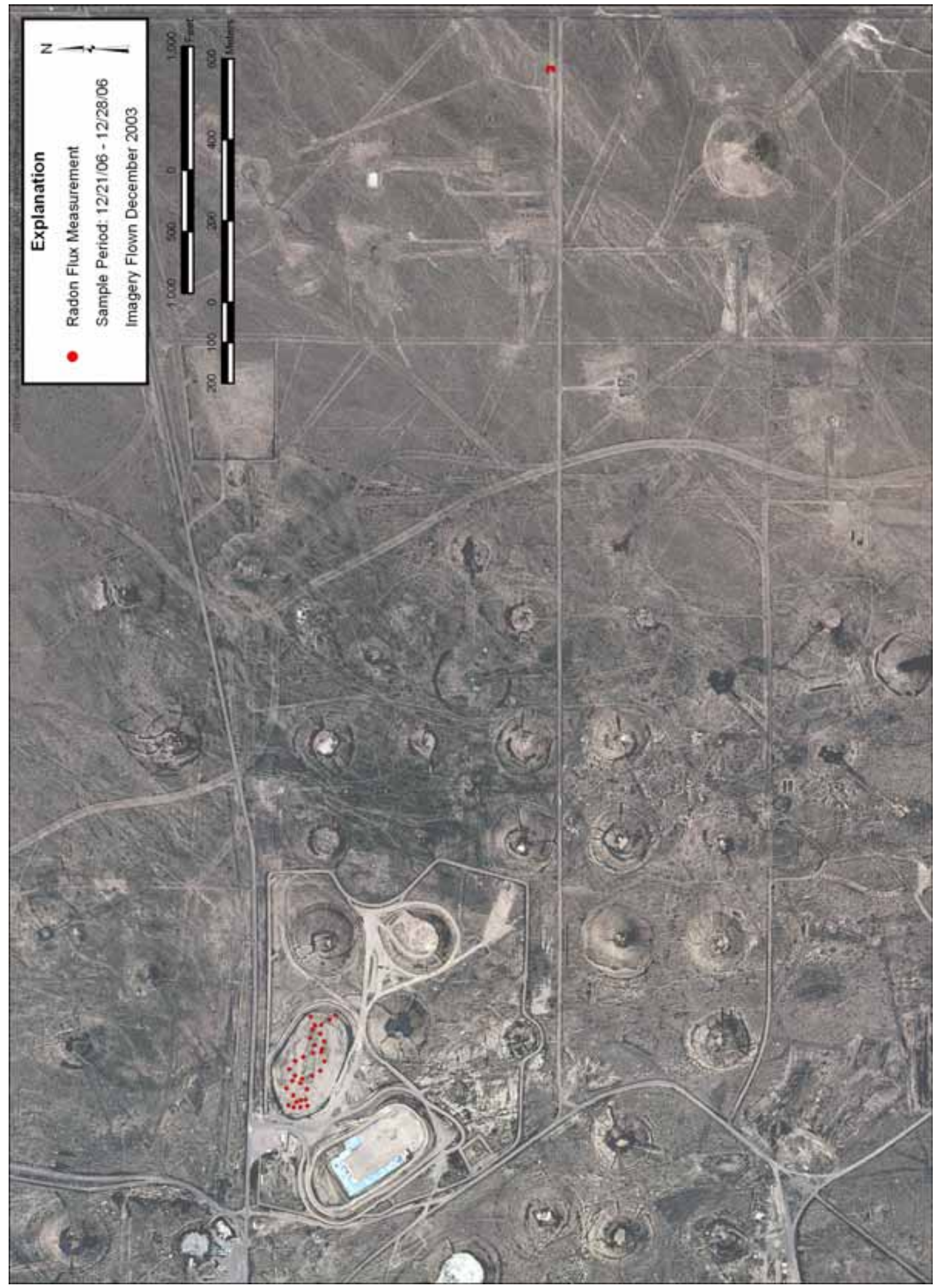

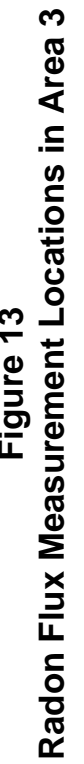




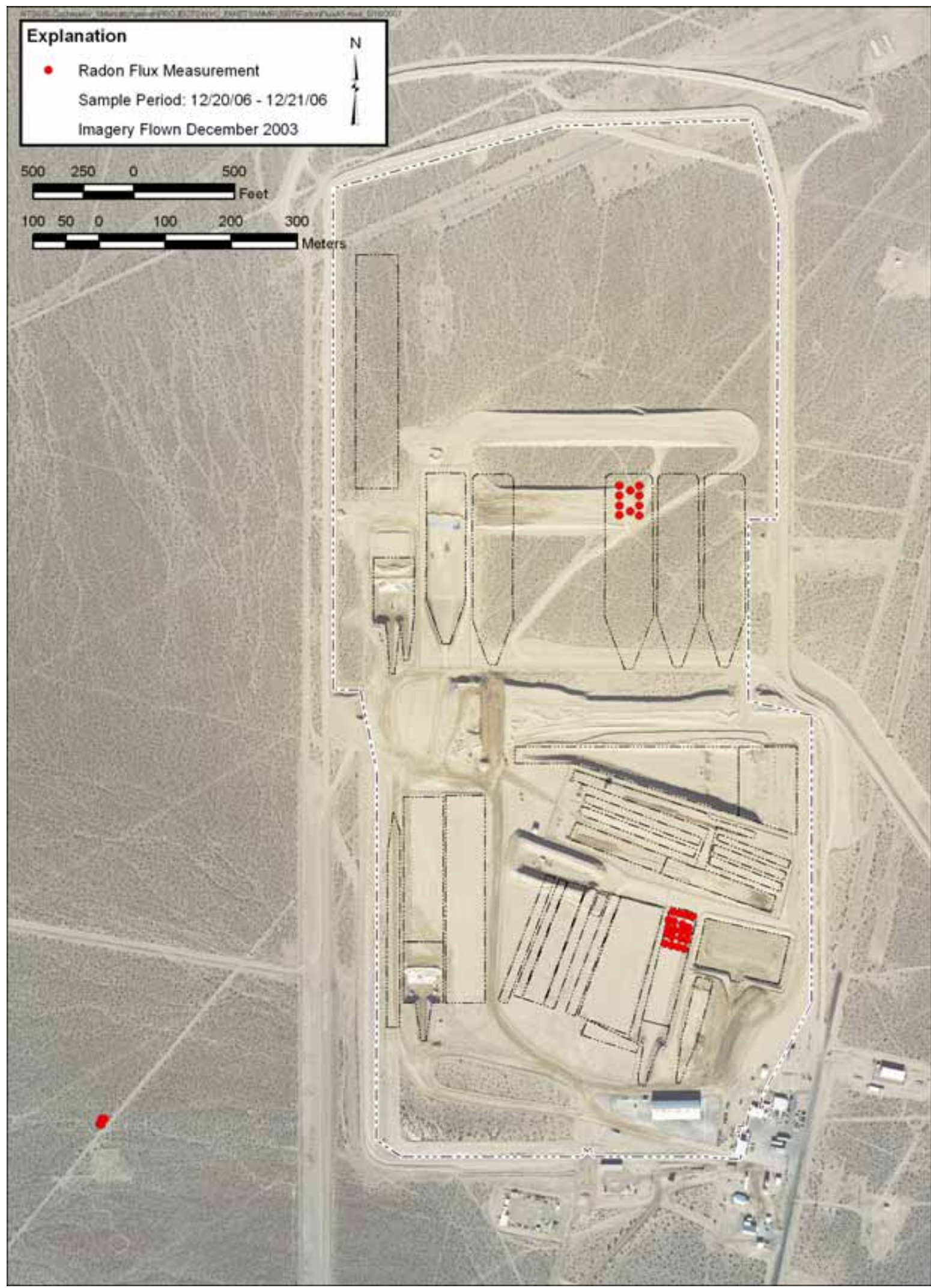

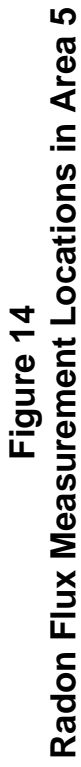




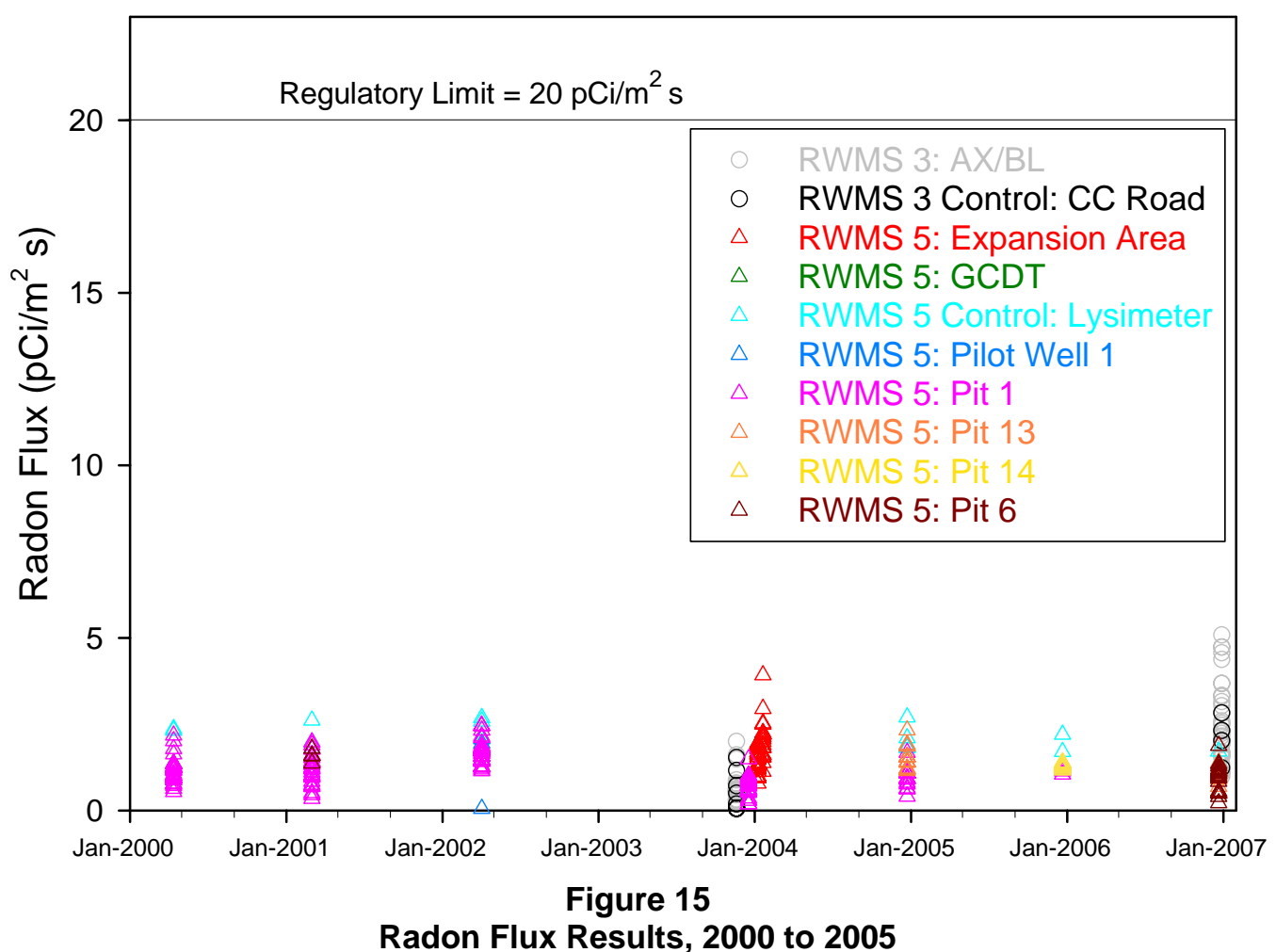

\section{Groundwater Monitoring Data}

Three pilot wells (UE5PW-1, UE5PW-2, and UE5PW-3) were drilled around the perimeter of the Area 5 RWMS in 1993 (see Figure 5). The groundwater at these wells is sampled twice a year. SC, pH, TOC, TOX, and tritium are measured as indicators of contamination migration. General water chemistry parameters are also measured. To date, all analytical data from groundwater sampling events from the wells indicate that the groundwater in the uppermost aquifer is unaffected by activities at the Area 5 RWMS. Detailed information and data on the groundwater monitoring program at the Area 5 RWMS are presented in the Nevada Test Site 2006 Data Report: Groundwater Monitoring Program, Area 5 Radioactive Waste Management Site (NSTec, 2007).

Groundwater elevation measurements are taken quarterly using an electronic tape. All groundwater elevation data from manual measurements taken since the wells were drilled in 1993 are shown in Figure 16. These data indicate that the water table beneath the Area 5 RWMS is flat, with little or no groundwater flow.

\section{Meteorology Monitoring Data}

Meteorology monitoring data collected in 2006 include precipitation, air temperature, humidity, wind speed and direction, barometric pressure, and incoming solar radiation. These are basic meteorological parameters required to quantify the exchange of water and heat between the soil and the atmosphere. These data were collected from two meteorology stations, one located approximately $30 \mathrm{~m}(100 \mathrm{ft})$ northwest of the Area $3 \mathrm{RWMS}$, and one near the Area 5 RWMS about $100 \mathrm{~m}$ (328 ft) from Well UE5PW-1 (see Figures 3 and 4). 


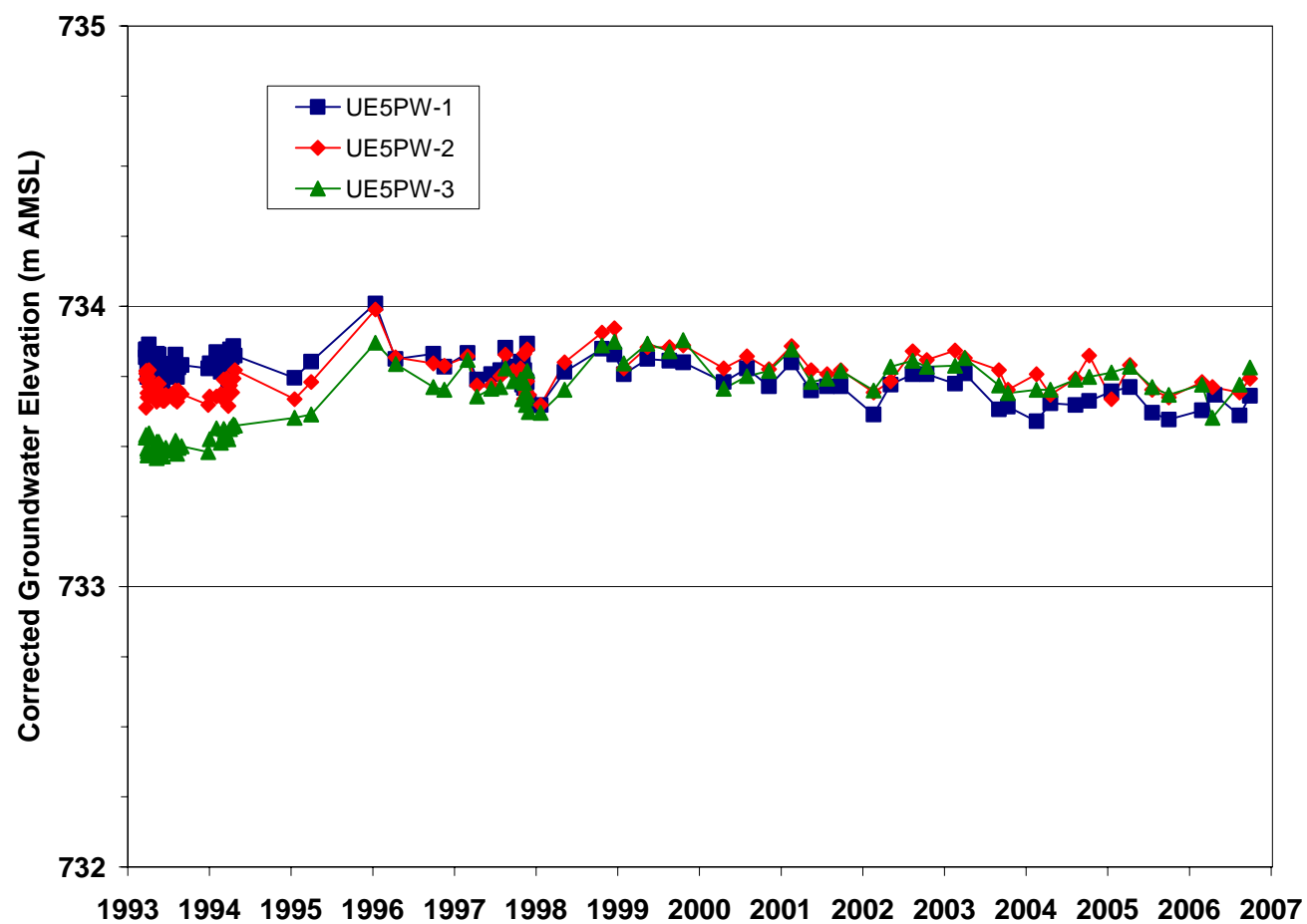

Figure 16

Groundwater Elevation Measurements Recorded at the Three Area 5 RWMS Pilot Wells by Tagging

\section{Air Temperature}

Air temperatures at the Area 3 RWMS are slightly cooler than air temperatures at the Area 5RWMS. The 2006 average recorded temperatures at $3 \mathrm{~m}(10 \mathrm{ft})$ are $13.7^{\circ} \mathrm{C}\left(56.7^{\circ} \mathrm{F}\right)$ at the Area $3 \mathrm{RWMS}$, and $16.5^{\circ} \mathrm{C}\left(61.7^{\circ} \mathrm{F}\right)$ at the Area $5 \mathrm{RWMS}$. The 2006 maximum and minimum temperatures at $3 \mathrm{~m}(10 \mathrm{ft})$ are $40.8^{\circ} \mathrm{C}\left(105.4^{\circ} \mathrm{F}\right)$ and $-14.4^{\circ} \mathrm{C}\left(6.1^{\circ} \mathrm{F}\right)$ at the Area $3 \mathrm{RWMS}$ and $43.2^{\circ} \mathrm{C}\left(109.8^{\circ} \mathrm{F}\right)$ and $-10.7^{\circ} \mathrm{C}\left(12.7^{\circ} \mathrm{F}\right)$ at the Area5 RWMS (Figure 17).

\section{Relative Humidity}

Measured relative humidity at the Area 3 RWMS and the Area 5 RWMS are similar. The average relative humidity during 2006 at these two sites is 32 percent (Figure 18).

\section{Barometric Pressure}

Average daily barometric pressure measured at the Area 3 RWMS and the Area 5 RWMS show very similar patterns (Figure 19). The difference in barometric pressure readings between the two locations is caused by the 261-m (856-ft) difference in elevation.

\section{Wind Speed and Direction}

The average wind speed is slightly higher at the Area 3 RWMS than at the Area 5 RWMS. During 2006, the average wind speed at the Area 3 RWMS was 3.0 meters per second (m/s) (6.7 miles per hour [mph]) and the maximum gust was $17.9 \mathrm{~m} / \mathrm{s}(40.0 \mathrm{mph})$. During 2006, the average wind speed at the Area 5 RWMS was $2.6 \mathrm{~m} / \mathrm{s}(5.8 \mathrm{mph})$ and the maximum gust was $18.5 \mathrm{~m} / \mathrm{s}$ (41.4 mph). Daily maximum and average wind speeds are in Figures 20 and 21. 


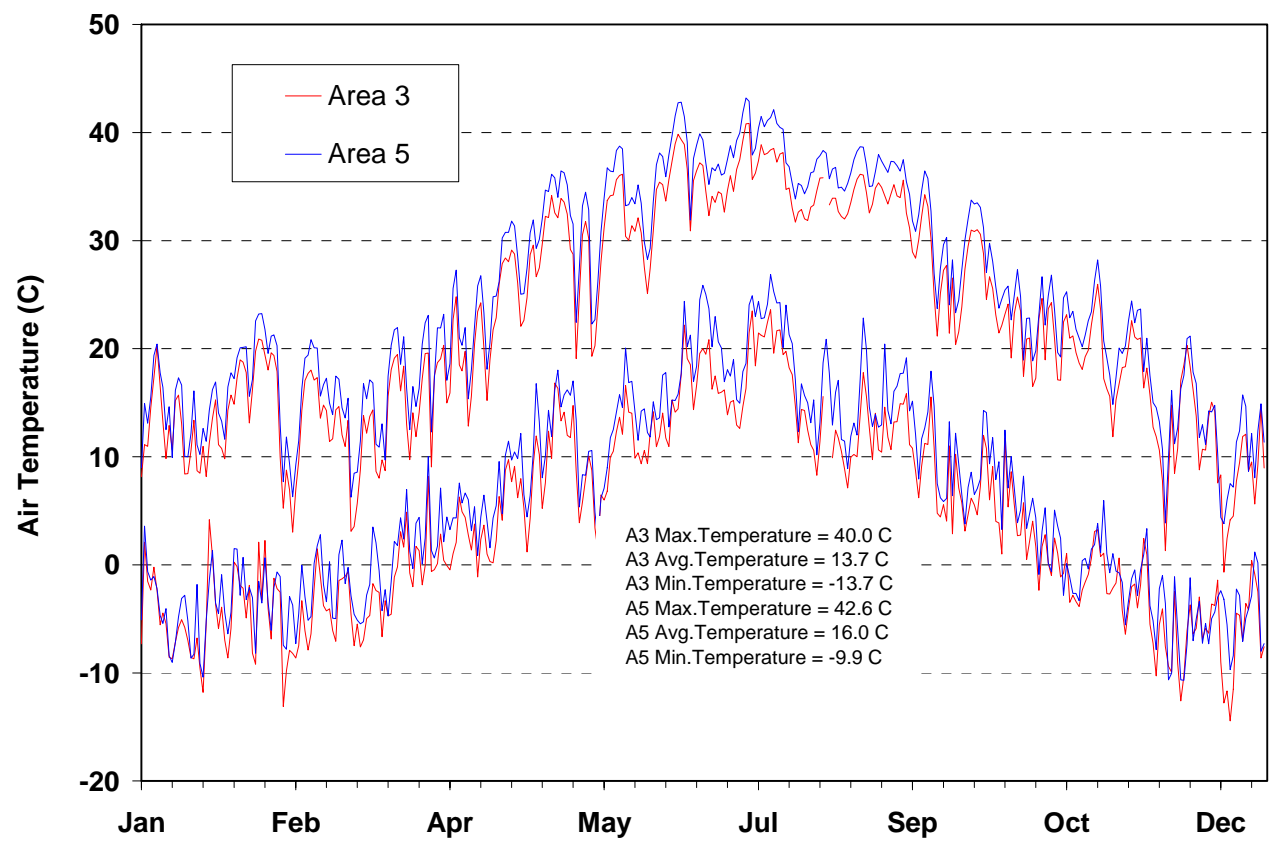

Figure 17

Daily Maximum and Minimum Air Temperatures at the Area 3 and Area 5 RWMSs

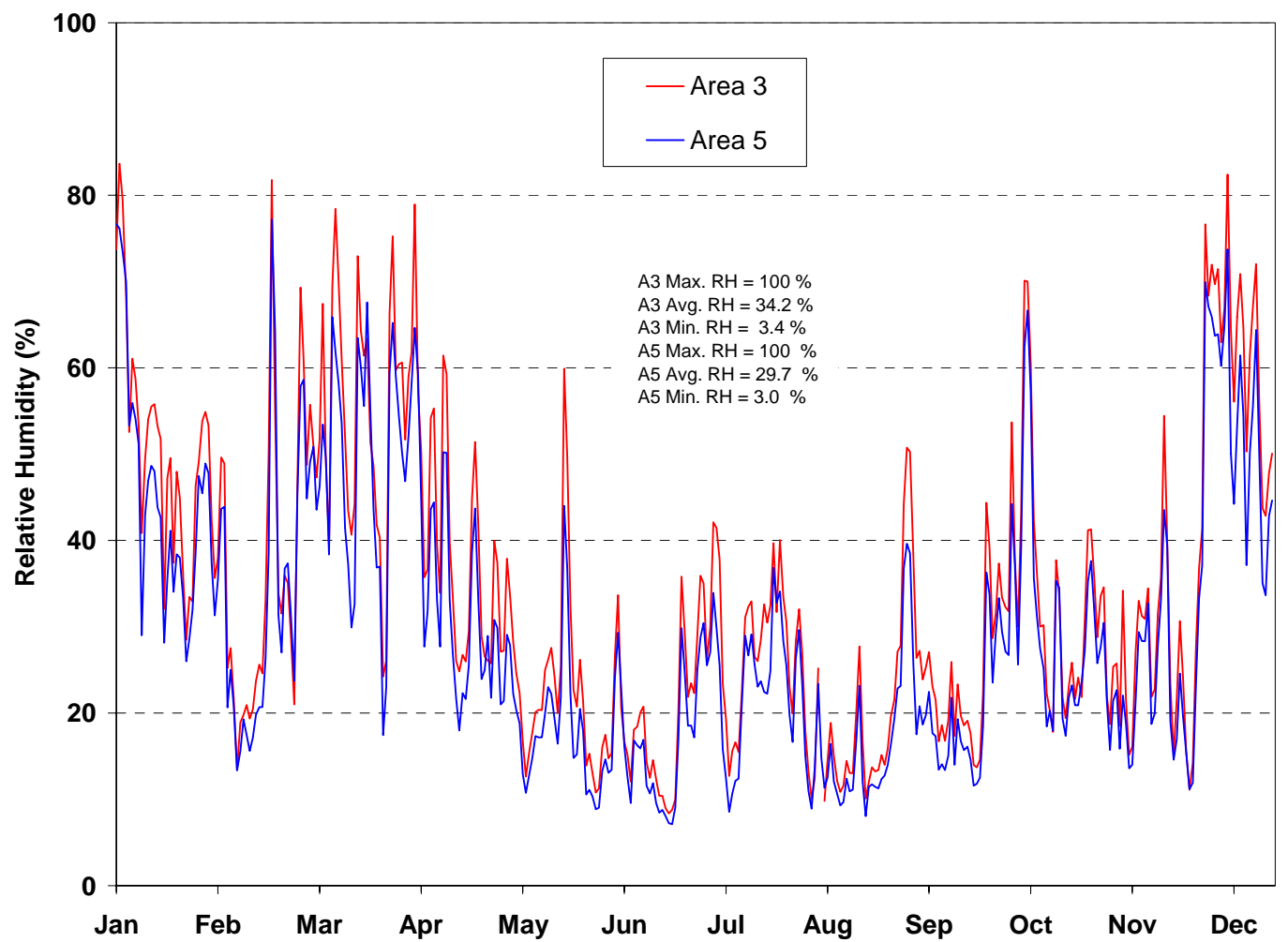

Figure 18

Daily Average Humidity Recorded at Area 3 and Area 5 RWMS Meteorology Stations 


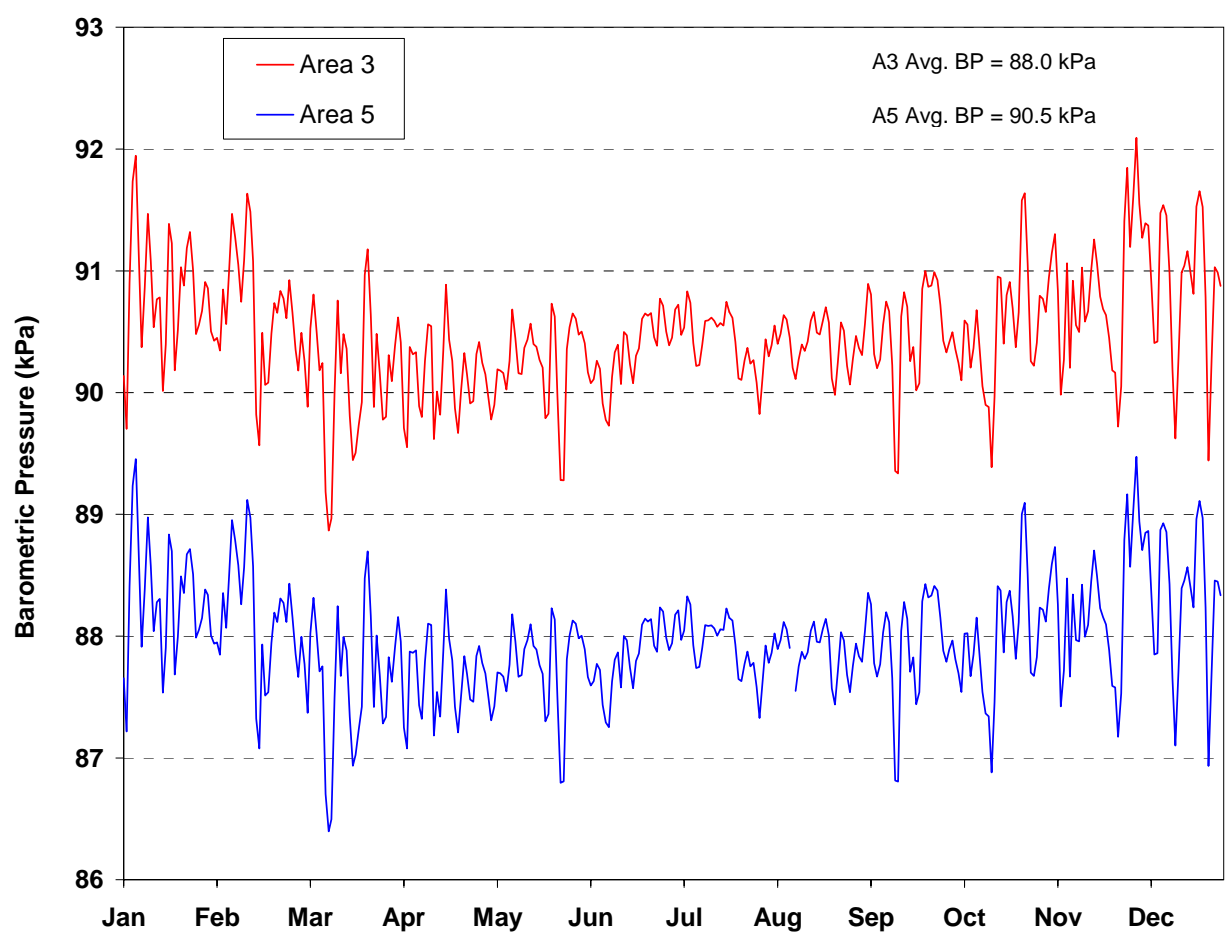

Figure 19

Daily Average Barometric Pressure Recorded at Area 3 and Area 5 RWMS Meteorology Stations

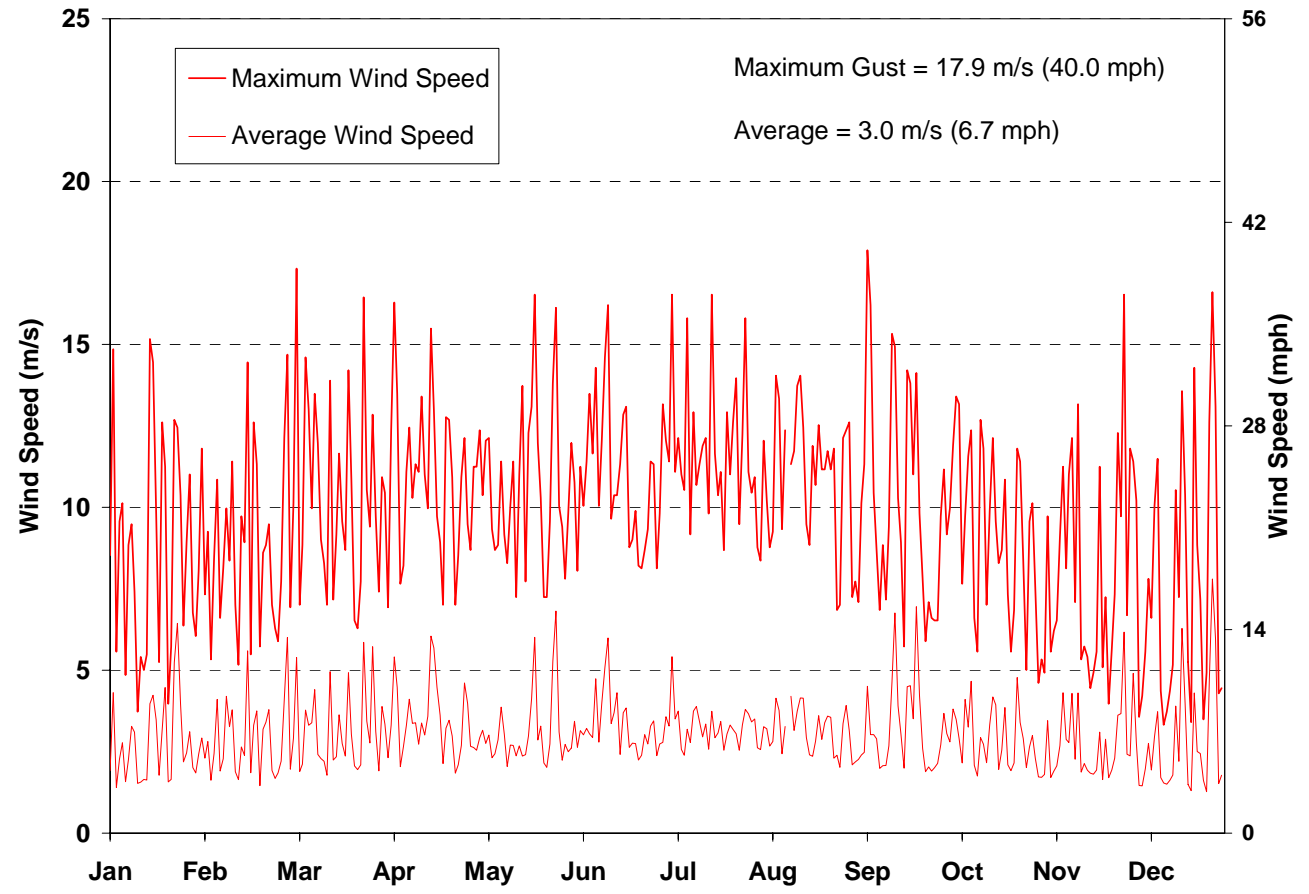

Figure 20

Daily Wind Speed Recorded at the Area 3 Meteorology Station at a Height of $3 \mathbf{~ m}$ 


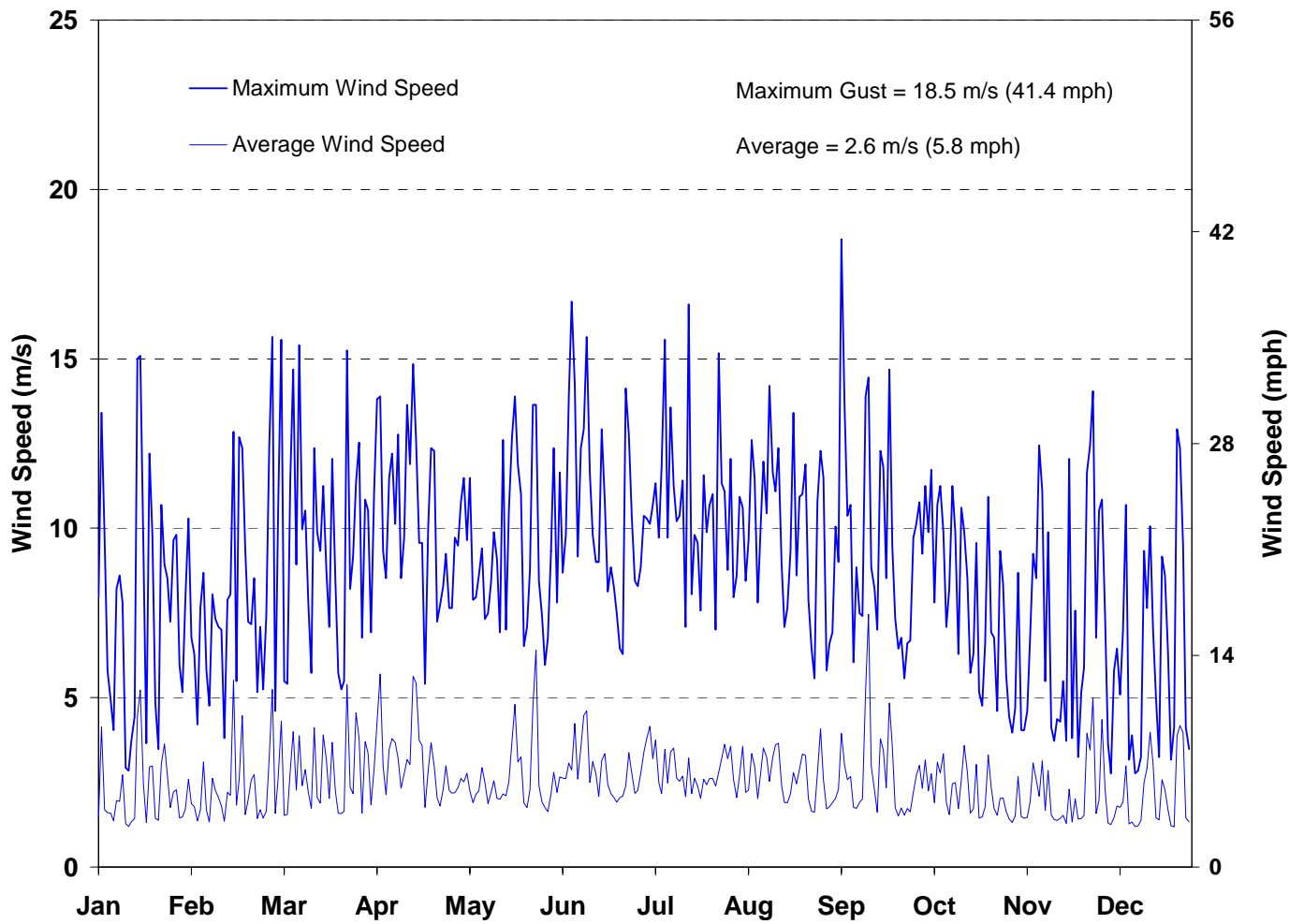

Figure 21

Daily Wind Speed Recorded at the Area 5 RWMS Meteorology Station at a Height of $3 \mathrm{~m}$

Wind rose diagrams provide wind direction and wind speed distribution in each direction using hourly wind data measured at a height of $3 \mathrm{~m}$ AGL. Generally, more wind comes from the north and higher wind speeds come from the south. Wind roses from the Area 3 and Area 5 RWMSs are presented in Figures 22 and 23, respectively. The one-year wind roses presented here are very similar to the multiple-year wind roses.

\section{Precipitation}

Rainfall at the Area 3 RWMS in 2006 was below average, totaling $87.2 \mathrm{~mm}$ (3.43 in.). The average annual precipitation measured at the Area 3 RWMS for 1996 to 2006 is $160.1 \mathrm{~mm}$ (6.30 in.). Only 2002 was drier than 2006, with $26.2 \mathrm{~mm}$ (1.03 in.) of precipitation. The maximum daily rainfall at the Area 3 RWMS during 2006 was 15.9 mm (0.63 in.) on March 28, 2006.

Rainfall at the Area 5 RWMS in 2006 was also below average, totaling $80.7 \mathrm{~mm}$ (3.18 in.). The average annual precipitation measured at the Area 5 RWMS for 1995 to 2006 is $131.3 \mathrm{~mm}$ (5.17 in.). Only 2002 (with 37.7 mm [1.48 in.]) and 1996 (with $76.8 \mathrm{~mm}$ [3.02 in.]) had less precipitation than 2006. The maximum daily rainfall at the Area 5 RWMS during 2006 was 21.7 mm (1.12 in.) on March 28, 2006. Figures 24 and 25 depict the 2006 daily total precipitation at the Area 3 and Area 5 RWMSs. 


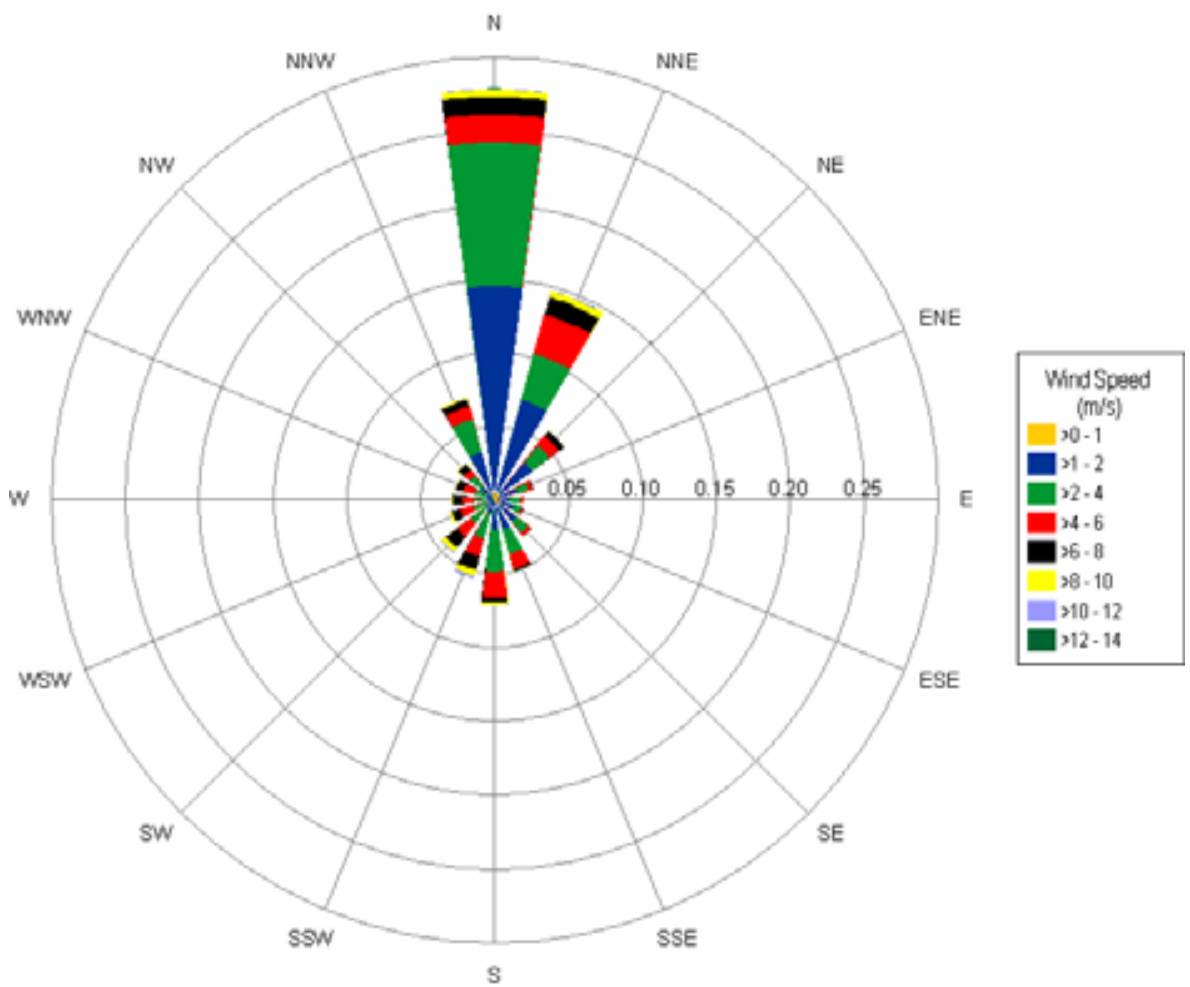

Figure 22

Wind Rose Diagram for the Area 3 RWMS Meteorology Station

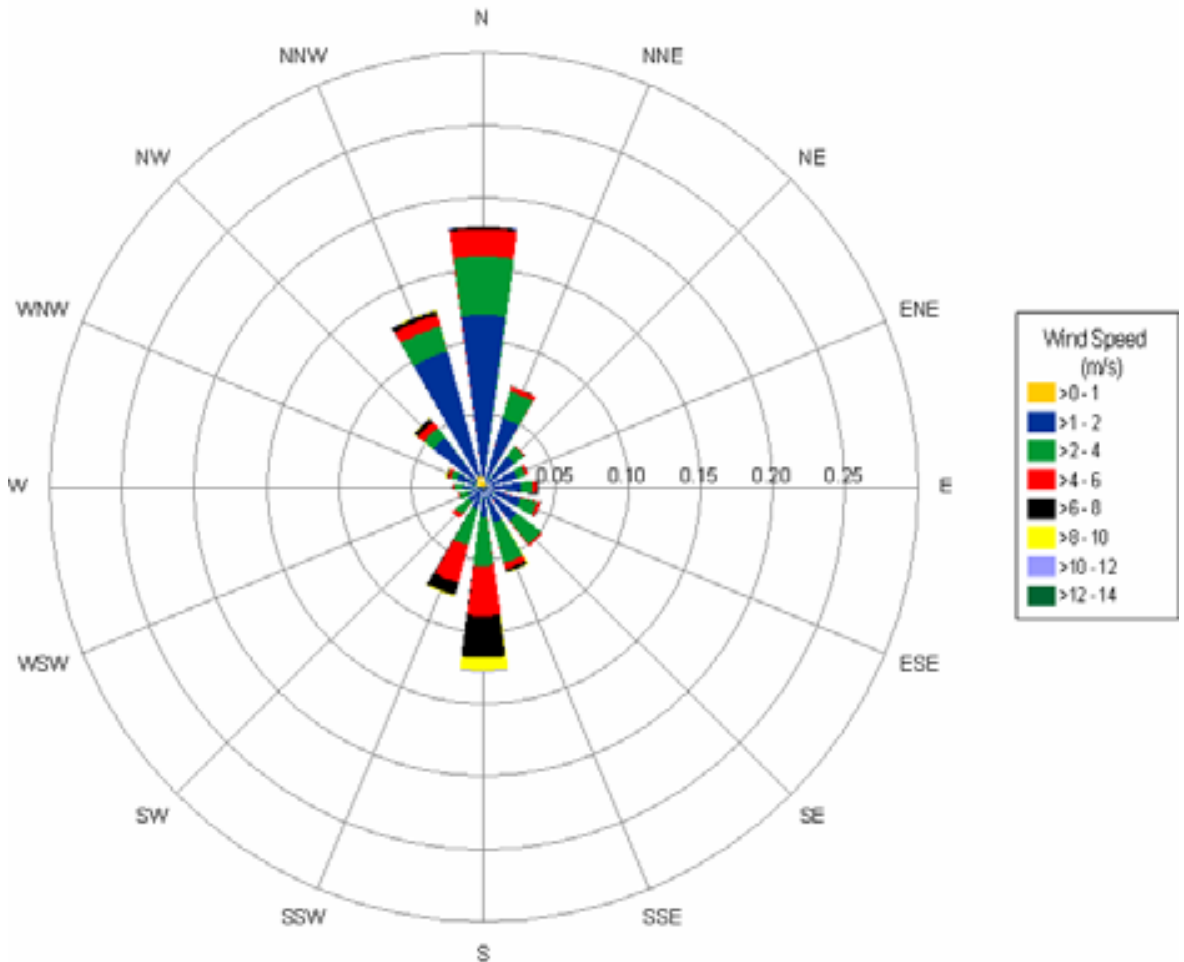

Figure 23

Wind Rose Diagram for the Area 5 RWMS Meteorology Station 


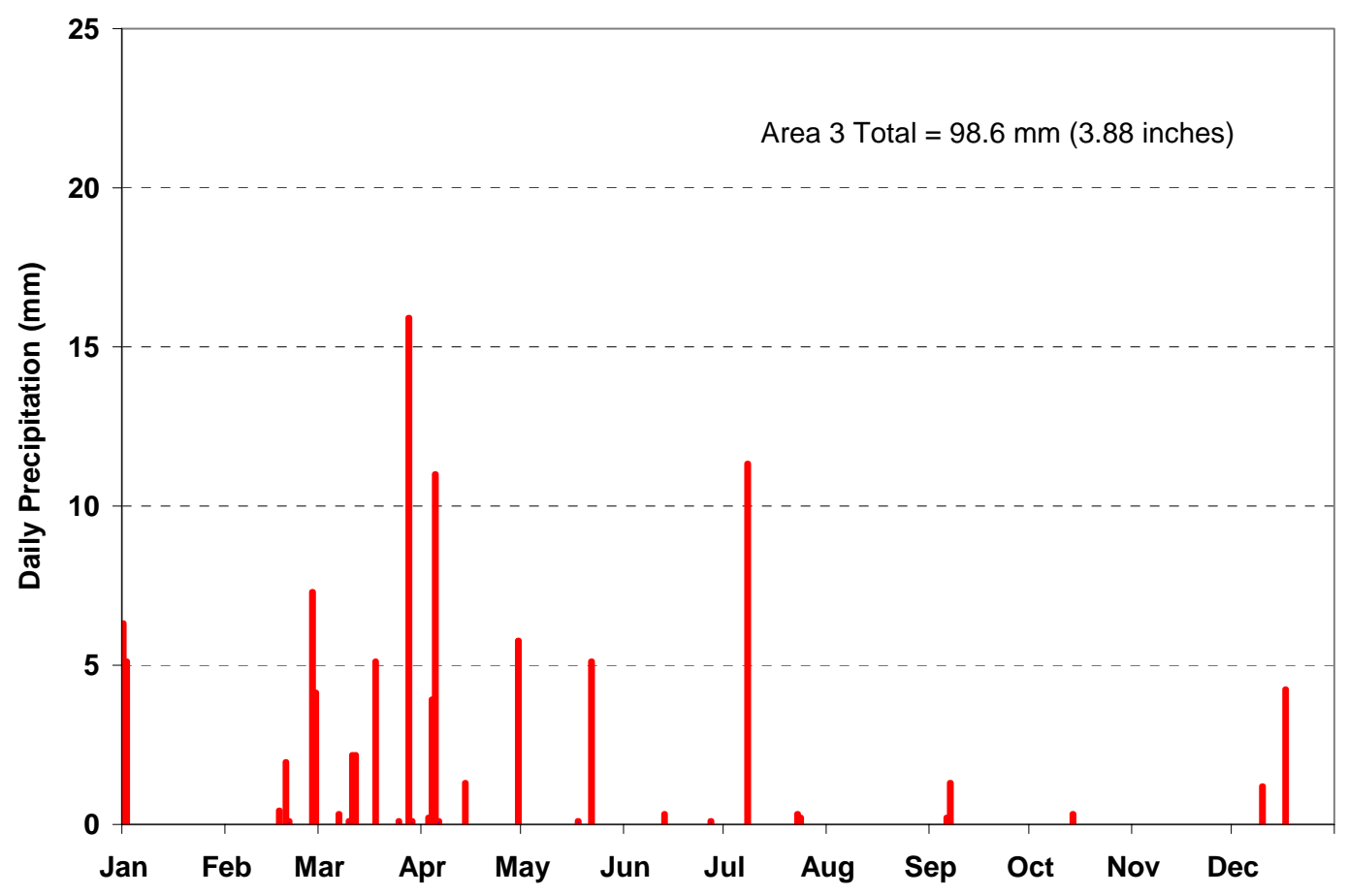

Figure 24

Daily Precipitation Recorded at the Area 3 RWMS Meteorology Station

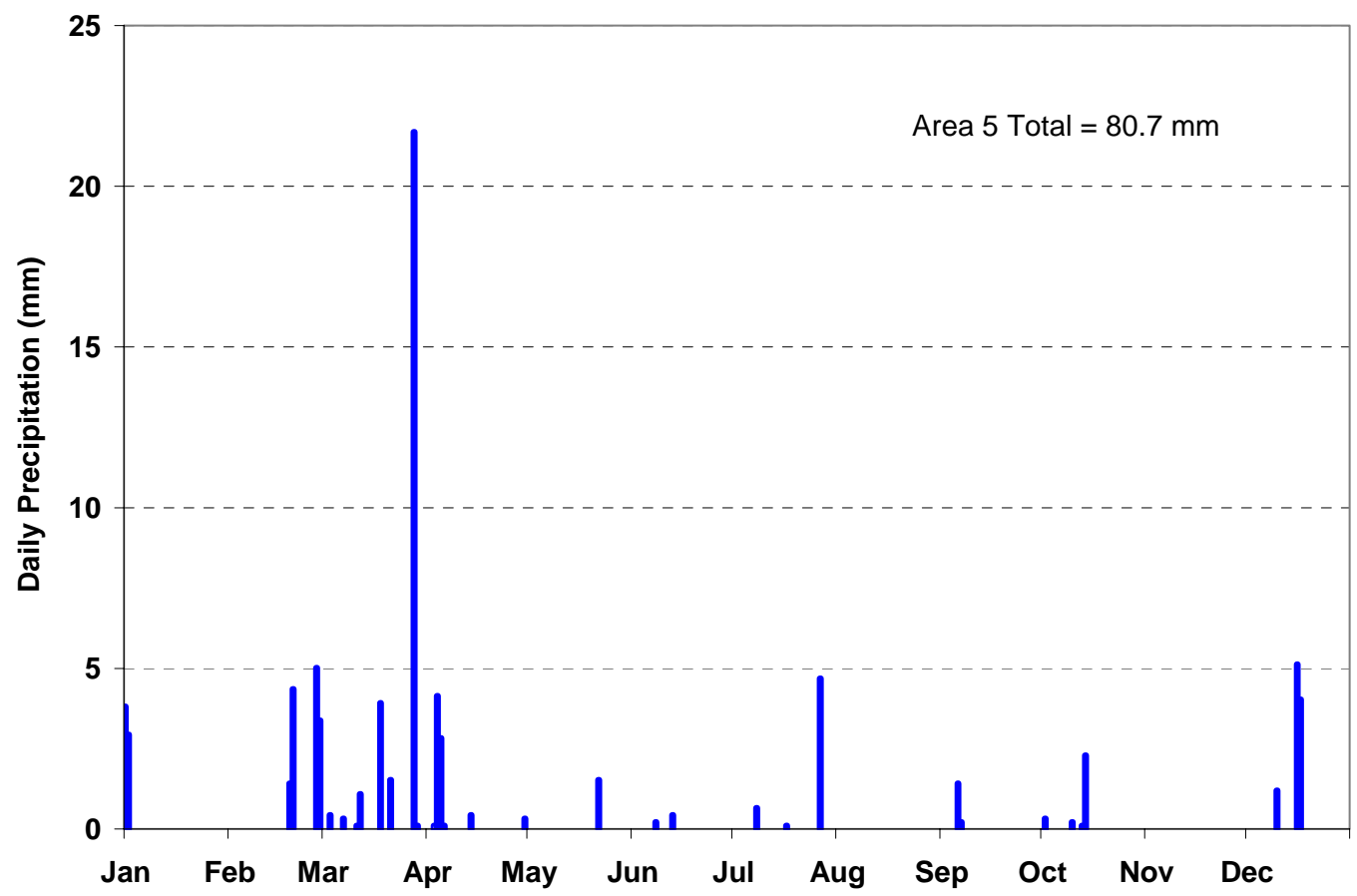

Figure 25

Daily Precipitation Recorded at the Area 5 RWMS Meteorology Station 
Historical precipitation data recorded at the Buster-Jangle Y (BJY) station (located about $3 \mathrm{~km}$ [2 mi] northwest of the Area 3 RWMS) and at the Area 3 RWMS are in Figure 26. The BJY station is a Meteorological Data Acquisition (MEDA) station operated by the Air Resources Laboratory Special Operations and Research Division (ARL/SORD). The 46-year average annual precipitation at BJY from 1961 to 2006 is $164.1 \mathrm{~mm}$ (6.46 in.). Historical precipitation data recorded at the Well 5B station (located about $5.5 \mathrm{~km}$ [3.4 mi] south of the Area 5 RWMS) and the Area 5 RWMS are provided in Figure 27. The Well 5B station is also an ARL/SORD MEDA station. The 44-year average annual precipitation at Well 5B from 1963 to 2006 is $124.9 \mathrm{~mm}$ (4.92 in.).

\section{PET}

The total calculated PET in 2006 at the Area 3 RWMS is 1,362 mm (53.6 in.) and at the Area 5 RWMS is 1,650 mm (65.0 in.). Total PET is derived using a modified version of the radiationbased equation of Doorenbos and Pruitt (1977). The equation calculates PET from hourly measurements of solar radiation, air temperature, relative humidity, wind speed, and barometric pressure. This method provides results similar to the Penman Equation that was previously employed for the data reports through 2001 (Campbell, 1977). The Doorenbos and Pruitt equation reduces data input requirements because no net radiation data are used. The ratio of PET to precipitation in 2006 at the Area 3 RWMS is 15.6, and the ratio of PET to precipitation in 2006 at the Area 5 RWMS is 20.4. The ratio of PET to precipitation is higher than normal because there was below-average rainfall in 2006 and annual PET is fairly constant.

\section{Vadose Zone Monitoring Data}

\section{Monitoring Strategy}

Vadose zone monitoring is conducted at the Area 3 and Area 5 RWMSs to demonstrate compliance with DOE Orders 5400.1 and 435.1, and confirm the assumptions made in the PA for each RWMS (e.g., hydrologic conceptual models, including soil water contents, upward and downward flux rates, and volatile radionuclide releases). The vadose zone monitoring is also performed to detect changing trends in performance, provide added assurance to PA conclusions regarding facility performance, evaluate the performance of the operational monolayer waste covers, and confirm the PA performance objective of protecting groundwater resources.

The current vadose zone monitoring program at the RWMSs is designed based on an understanding of the vadose zone system acquired through extensive characterization studies (BN, 1998; Blout et al., 1995; REECo, 1993a, 1993b, 1994; Schmeltzer et al., 1996; Shott et al., 1997, 1998; Tyler et al., 1996) and modeling studies (Levitt et al., 1999).

The objectives of the vadose zone monitoring program are accomplished, in part, by measuring water balances at each RWMS. Water balance studies involve using meteorology data to calculate PET values (the driving force of upward flow), directly measuring ET and bare-soil E at the RWMS lysimeter facilities, and measuring soil water content and soil water potential in waste cell covers and floors using automated waste cover monitoring systems. The vadose zone monitoring strategy also evaluates the subsurface migration of tritium by sampling soil gas for the presence of tritium at Well GCD-05U located near the center of Area 5 RWMS (see Figure 4). 


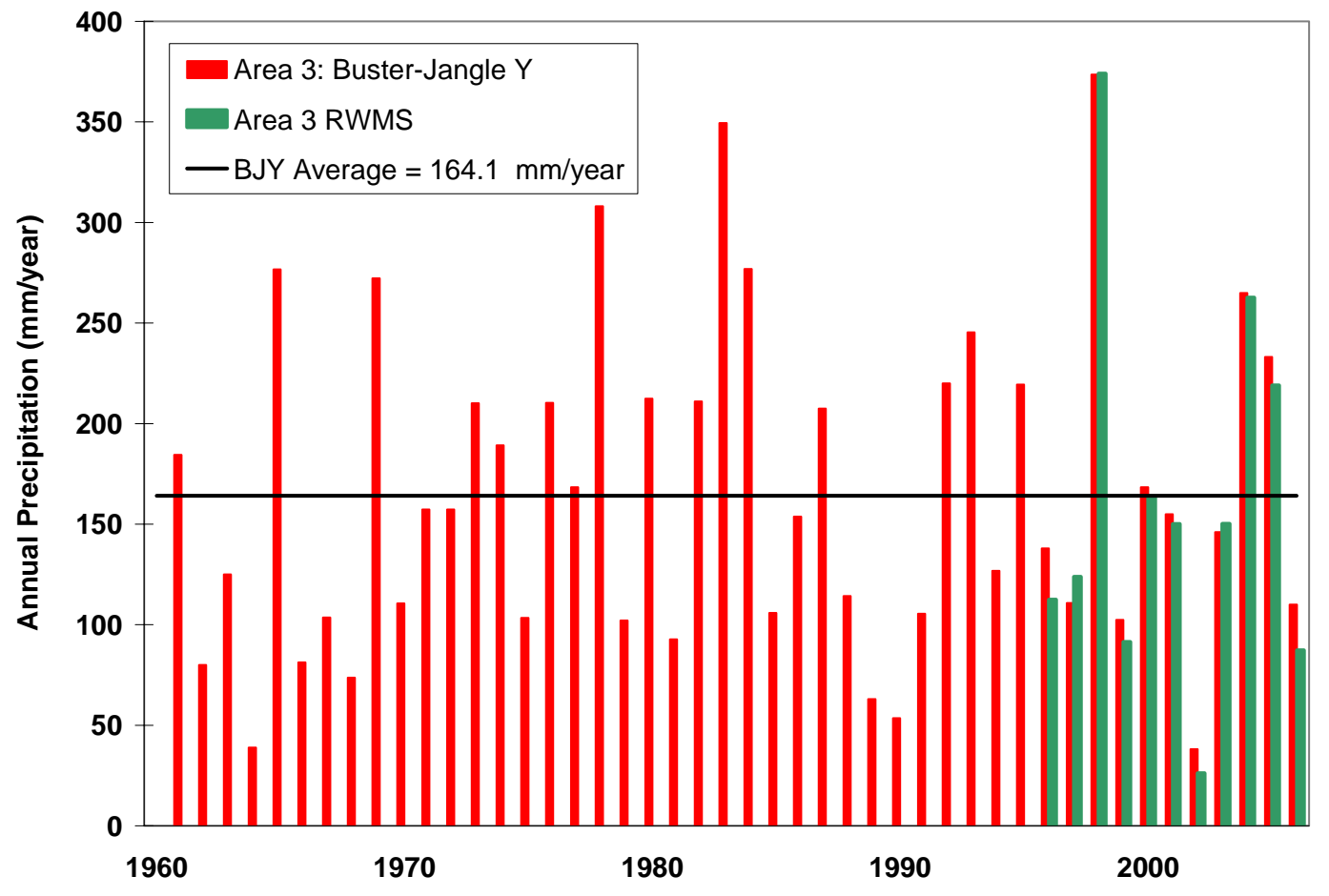

Figure 26

Historical Precipitation Record for the Area 3 Buster-Jangle Y and the Area 3 RWMS

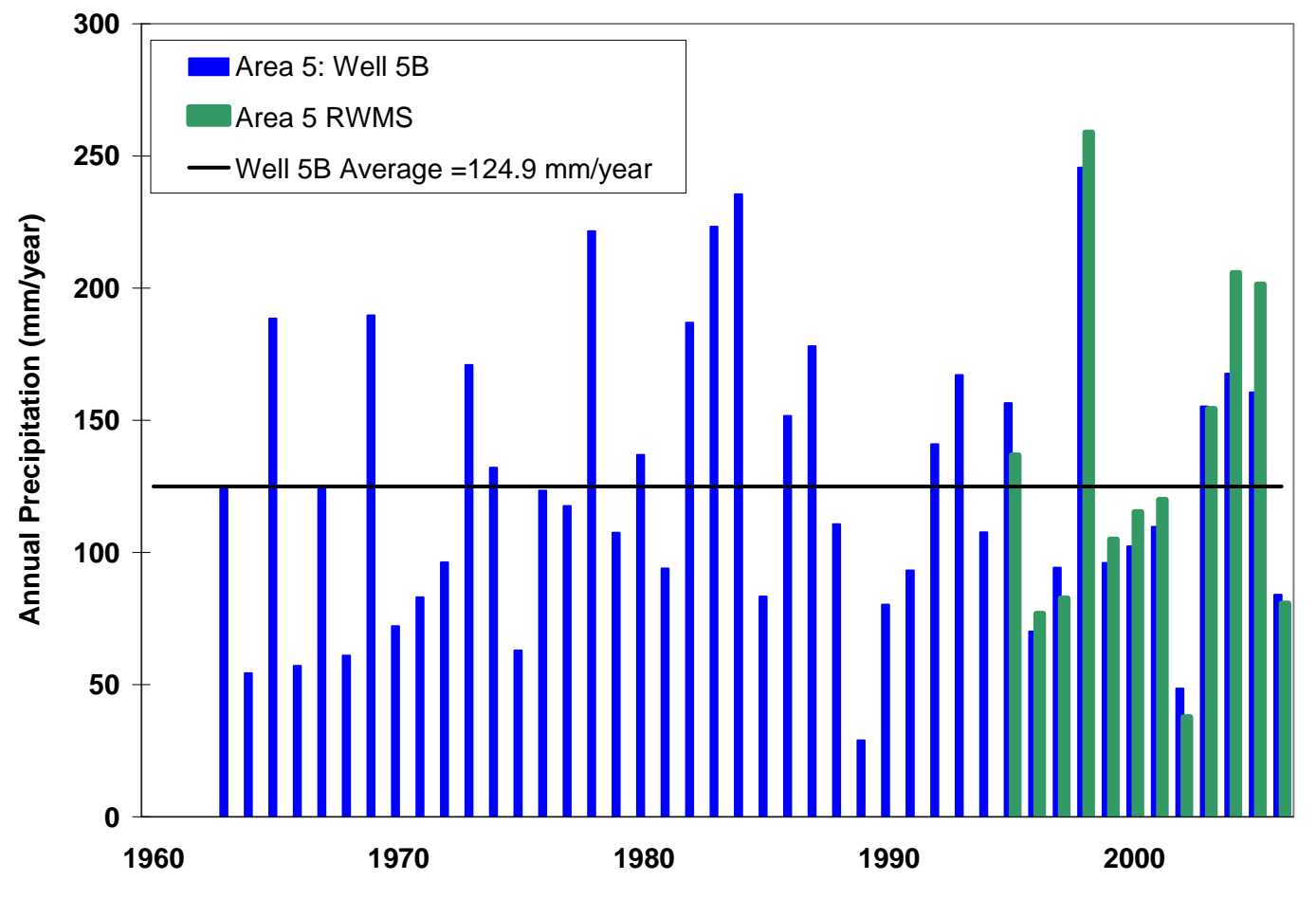

Figure 27

Historical Precipitation Record for Area Well 5B and the Area 5 RWMS 


\section{Soil Gas Tritium}

Soil gas tritium monitoring is conducted via soil gas sampling at Well GCD-05U. This 3-m(10-ft)-diameter borehole has a large tritium inventory ( 2.2 million Curies (Ci) at time of disposal) which is buried from 20 to $37 \mathrm{~m}$ (65 to $120 \mathrm{ft}$ ) below ground surface. Two strings of nine soil gas sampling ports are buried at depths of $3.0 \mathrm{~m}(10 \mathrm{ft}), 6.1 \mathrm{~m}(20 \mathrm{ft}), 9.1 \mathrm{~m}(30 \mathrm{ft})$, $12.2 \mathrm{~m}$ (40 ft), $15.2 \mathrm{~m}$ (50 ft), $19.8 \mathrm{~m}$ (65 ft), $25.9 \mathrm{~m}$ (85 ft), $33.5 \mathrm{~m} \mathrm{(110} \mathrm{ft),} \mathrm{and} 36.3 \mathrm{~m} \mathrm{(119} \mathrm{ft)}$ below ground surface. Soil gas is pumped from the sampling ports to the surface at a low flow rate (2 cubic centimeters [cm] per minute). A cold trap removes water vapor from the air stream, and the tritium activity of the water is measured by liquid scintillation. Approximately 30 liters of soil gas sample provides approximately 0.3 grams of water. Tritium sampling at Well GCD-05U provides a direct measure of changes in tritium activity with depth due to degradation of waste containers, advection, and diffusion. Sampling started in 1990 and has continued at least annually through 2006.

Soil gas tritium was sampled from the nine GCD 05U sampling depths in August 2006. The 17-year trend in results indicates that upward migration of tritium through soil from the waste level is extremely slow. Tritium concentrations have remained constant and low from the surface down to $12.2 \mathrm{~m}$ (40 ft). Tritium concentrations at $15.2 \mathrm{~m}$ (50 ft) slowly increased through 1997, but have since leveled off. The sample ports at depths of 19.8, 25.9, 33.5, and $36.3 \mathrm{~m}(65,85,110$, and $119 \mathrm{ft})$ are adjacent to the tritium source. Tritium concentrations at these depths have increased by a factor of three since 1990. The highest measured soil gas tritium concentration of 363.9 microCuries per $\mathrm{m}^{3}$ indicates that most of the 2.2 million $\mathrm{Ci}$ originally buried at the site remains contained. Soil gas tritium concentrations with depth and time are illustrated in Figures 28 and 29.

\section{Area 5 Weighing Lysimeter Facility}

The Area 5 Weighing Lysimeter Facility consists of two precision weighing lysimeters located about $400 \mathrm{~m}(1,312 \mathrm{ft})$ southwest of the Area $5 \mathrm{RWMS}$ (see Figure 5). Each lysimeter is a 2-m-wide $\times$ 4-m-long (6.6-wide $\times 13$-ft-long) by 2-m- (6.6-ft)-deep, open-top steel box filled with soil and mounted on a sensitive scale. Weight changes of each lysimeter are continuously monitored using an electronic loadcell. Each loadcell can measure approximately $0.1 \mathrm{~mm}$ ( 0.004 in.) of precipitation or ET. One lysimeter is vegetated with native plant species at the approximate density of the surrounding desert, and the other lysimeter is kept bare to simulate the bare operational waste covers at the Area 5 RWMS. The load cells have provided an accurate data set of the surface water balance at the Area 5 RWMS since March 1994.

The weighing lysimeter data represent a simplified water balance: the change in soil water storage is equal to precipitation minus E (on bare lysimeters) or ET (on vegetated lysimeters). The water balance is simplified because no drainage can occur through the solid bottoms of the lysimeters and because a 2.5-cm (1-in.) lip around the edge of the lysimeters prevents run-on and runoff. Total soil water storage for the period of March 30, 1994, through December 31, 2006, is illustrated in Figure 30. 


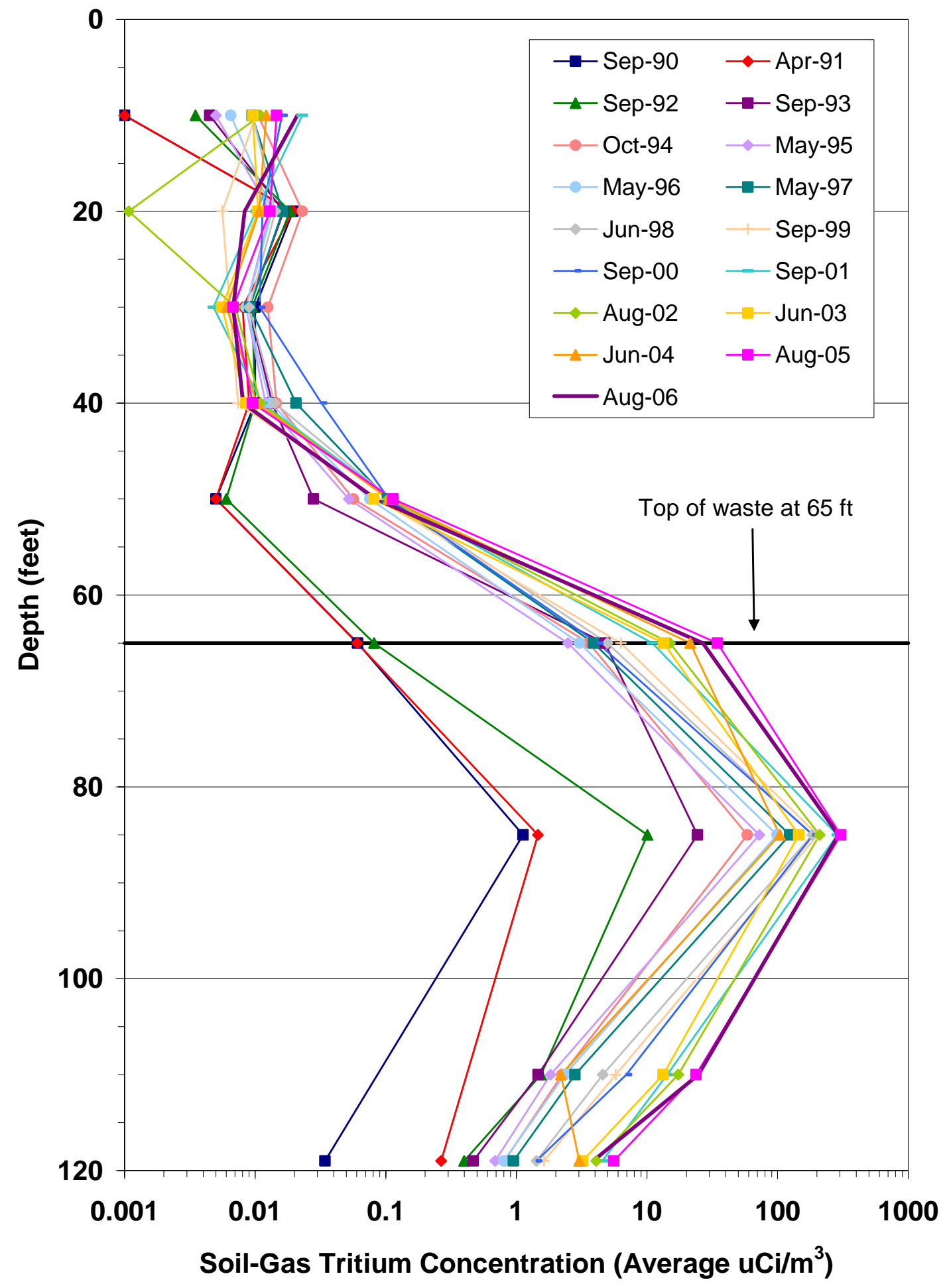

Figure 28

Soil Gas Tritium Concentrations with Depth at GCD-05U 

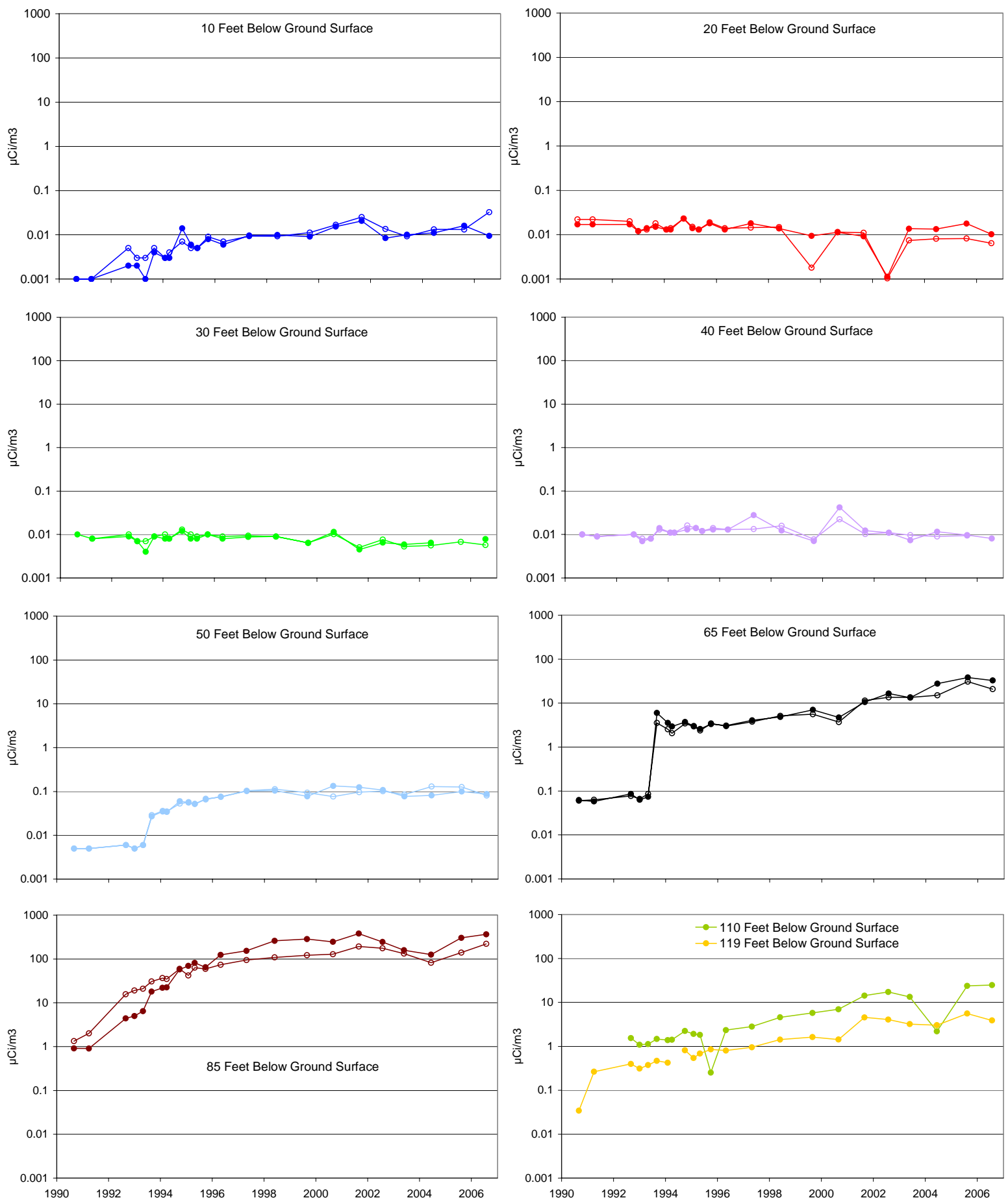

Figure 29

Soil Gas Tritium Concentration at Each Depth in GCD-05U 


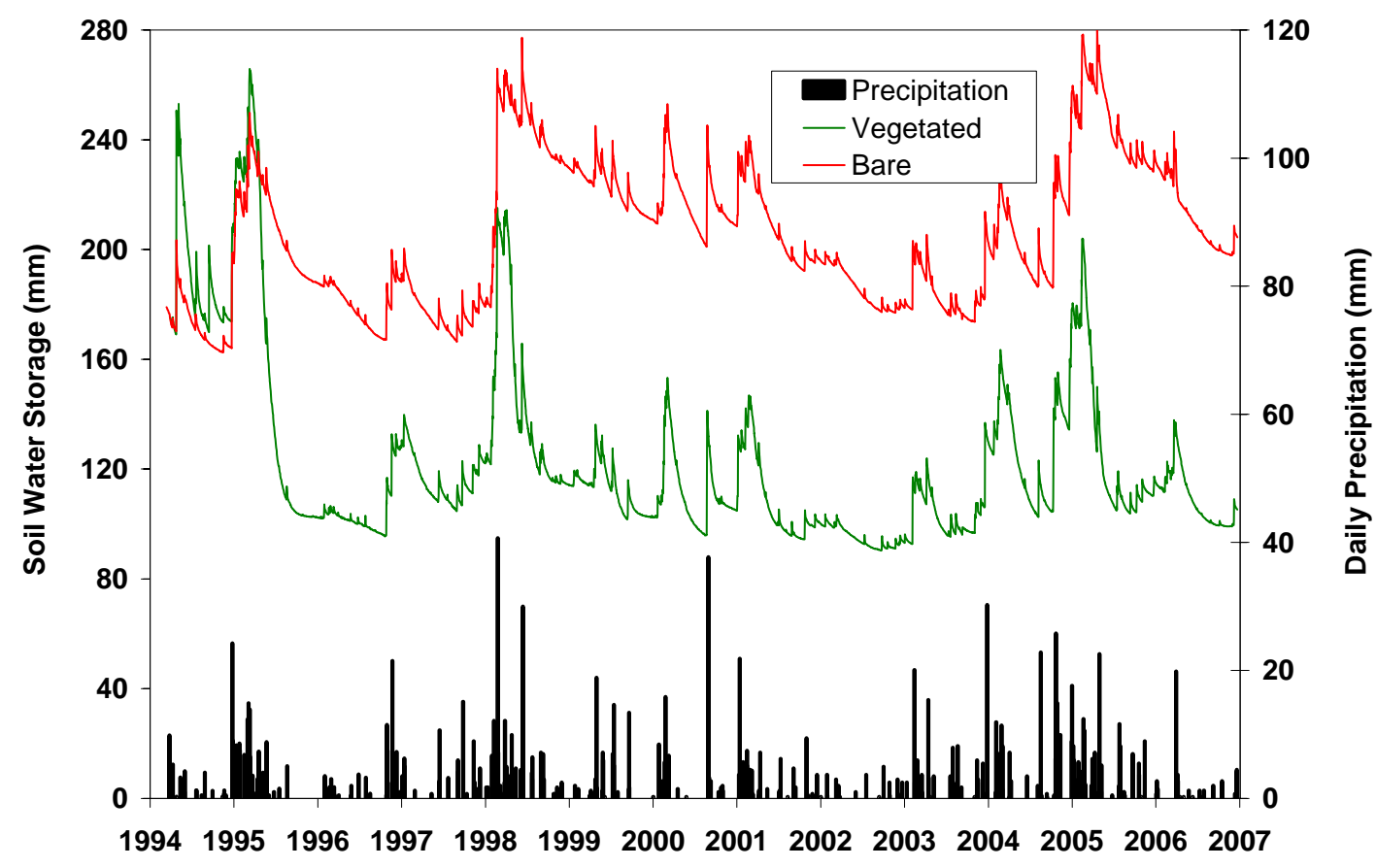

Figure 30

Weighing Lysimeter and Precipitation Data from March 1994 to December 2006

The vegetated lysimeter is considerably drier than the bare-soil lysimeter, despite the small number of plants on the vegetated lysimeter (about 15 percent plant cover). Soil water storage decreases rapidly in the vegetated lysimeter following high rainfall periods. Increases in soil water storage observed early in the data record in the vegetated lysimeter are a result of irrigation conducted to ensure survival of transplanted vegetation.

No water has ever accumulated at the bottom of the vegetated lysimeter. Heavy precipitation and low E rates during the period from October 2004 to February 2005, combined with initially high water contents, resulted in water accumulating at the bottom of the bare lysimeter starting in March 2005. This water continued to evaporate from the bare lysimeter during 2006, but some moisture remains at the bottom. Long-term numerical simulations (30 years) using a unit gradient bottom boundary were used to determine the amount of drainage that would have occurred if water could drain from the lysimeters. These simulations indicate an average of $1.0 \mathrm{~cm} / \mathrm{yr}$ of water reaches the bottom of the bare lysimeter and that essentially no water reaches the bottom of the vegetated lysimeter (Desotell et al., 2006).

During 2006, E from the bare lysimeter was $96.3 \mathrm{~mm}$ (3.8 in.) and ET from the vegetated lysimeter was $76.5 \mathrm{~mm}$ (3 in.). Because both E and ET were greater than the $70.6 \mathrm{~mm}$ (2.7 in.) of precipitation at the Weighing Lysimeter Facility, water storage decreased in both lysimeters (Figure 31). 


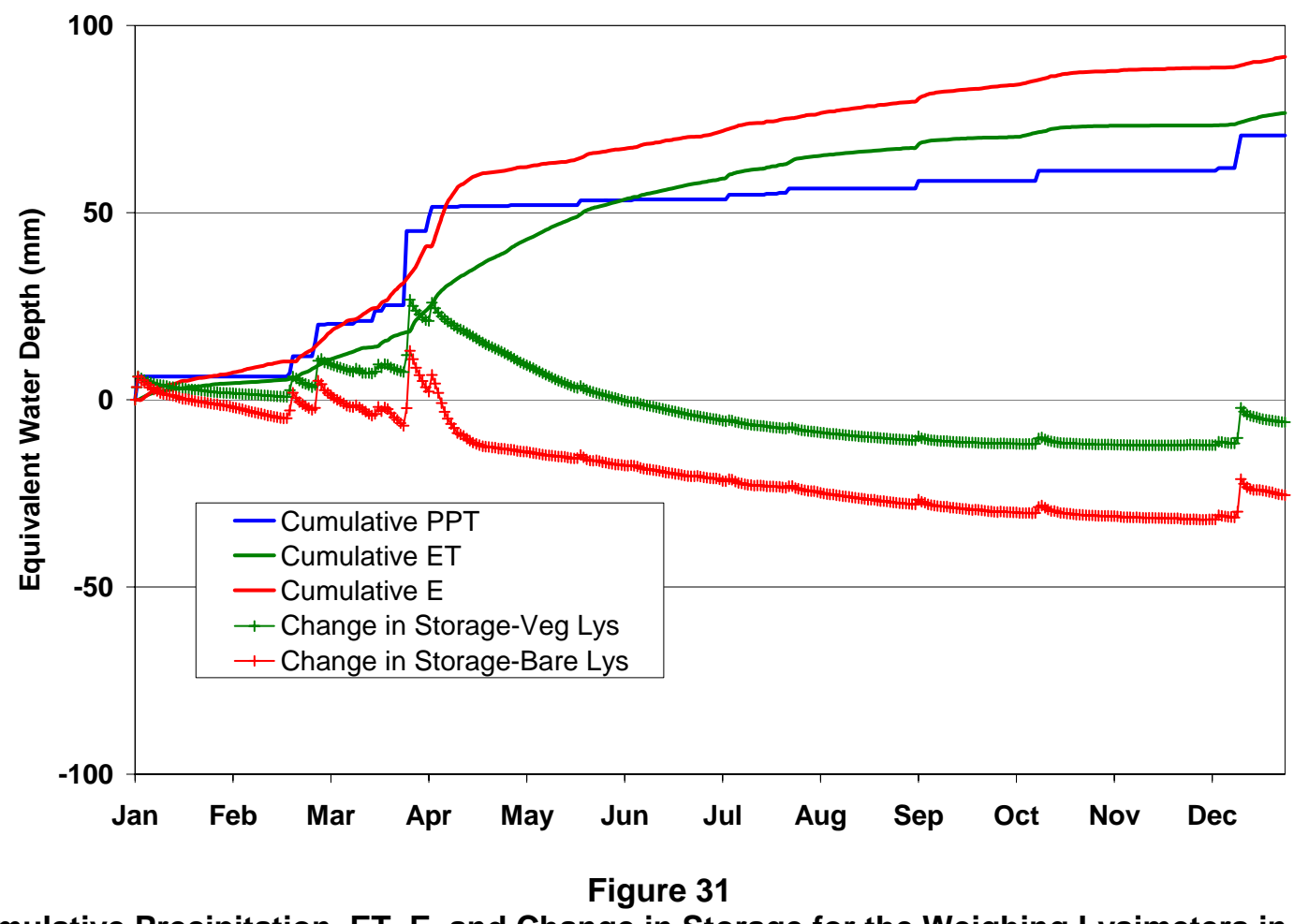

Cumulative Precipitation, ET, E, and Change in Storage for the Weighing Lysimeters in 2006

Precipitation exceeded ET in January, February, March, and December, and precipitation exceeded E in February, March, and December. E is greater than ET because the bare lysimeter is much wetter than the vegetated lysimeter resulting in more water near the surface for E. Also, there was rapid growth of annual plants on the bare lysimeter during March and April. These plants were not removed until mid April. This resulted in higher E during these months. By July, both lysimeters were very dry and E and ET were very low (Figure 32).

\section{Automated Waste Cover Monitoring System}

In 1998, an automated monitoring system was installed in Area 5 adjacent to Well UE5PW-1 at the Neutron Probe Calibration Facility. Time-domain reflectometry (TDR) sensors are used to measure water content around different types of casings used in neutron probe access holes. These measured water contents are used for calibrating neutron probes. This TDR system has 36 TDR probes buried at depths of 30,60, and $90 \mathrm{~cm}(1,2$, and $3 \mathrm{ft})$ around four different neutron probe access hole casing types. There are three replicate TDR sensors at each depth for each casing type. No neutron probes were calibrated during 2006.

In 1998, TDR probes were buried $1.2 \mathrm{~m}$ (4 ft) beneath the floor of open Pit 5 at the Area 5

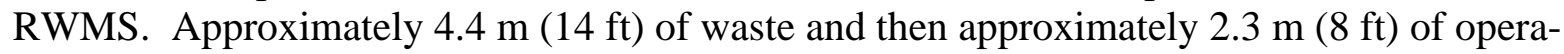
tional cover were placed above these probes during disposal operations. The total depth of these probes is now approximately $8.9 \mathrm{~m}(29 \mathrm{ft})$. Measured volumetric water content in the floor of Pit 5 has remained constant at approximately 10 percent (Figure 33). The constant measured water content indicates that no moisture has percolated to $1.2 \mathrm{~m}(4 \mathrm{ft})$ below the waste. 


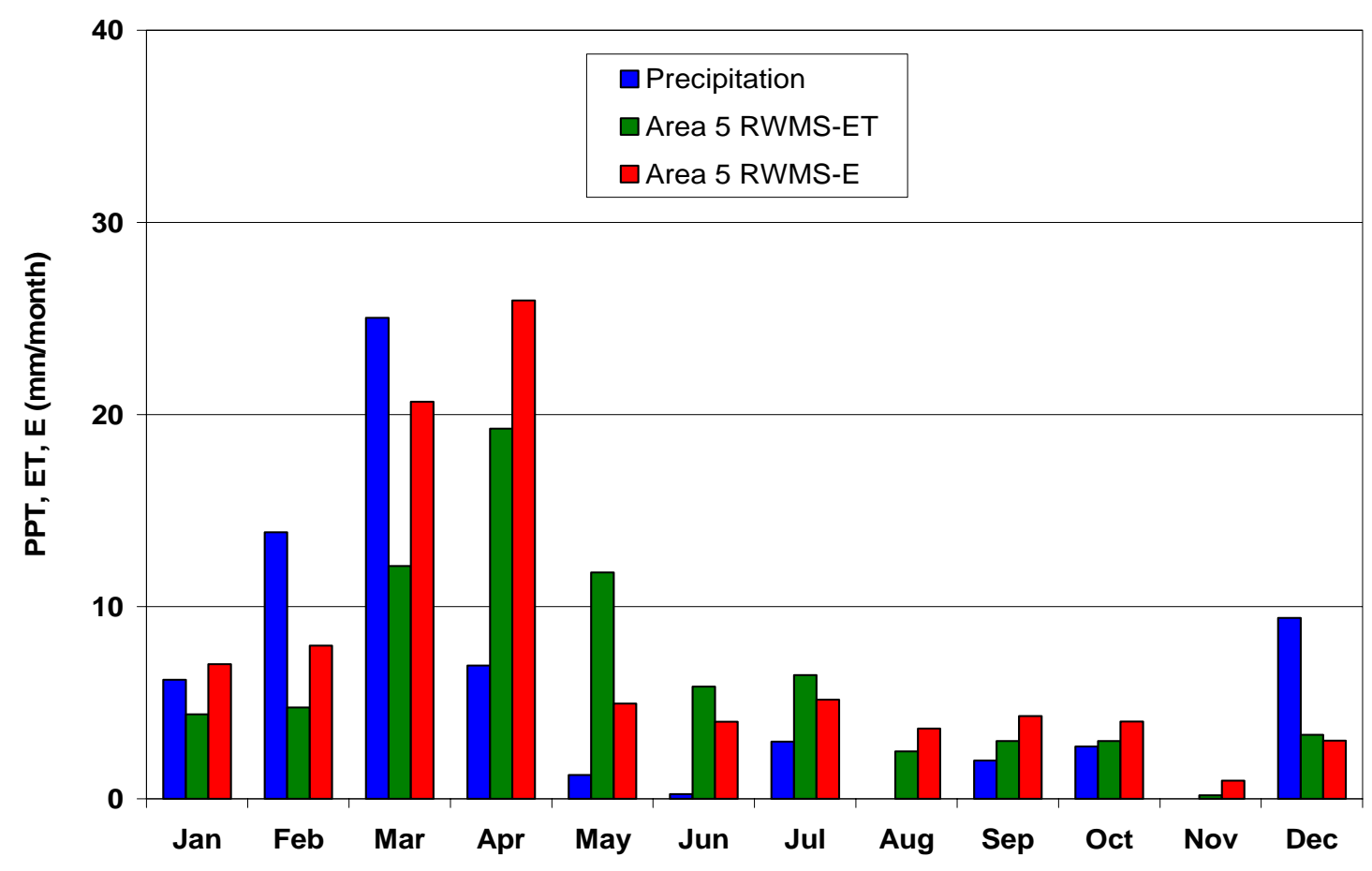

Figure 32

Monthly Precipitation, E, and ET Measured in Weighing Lysimeters in 2006

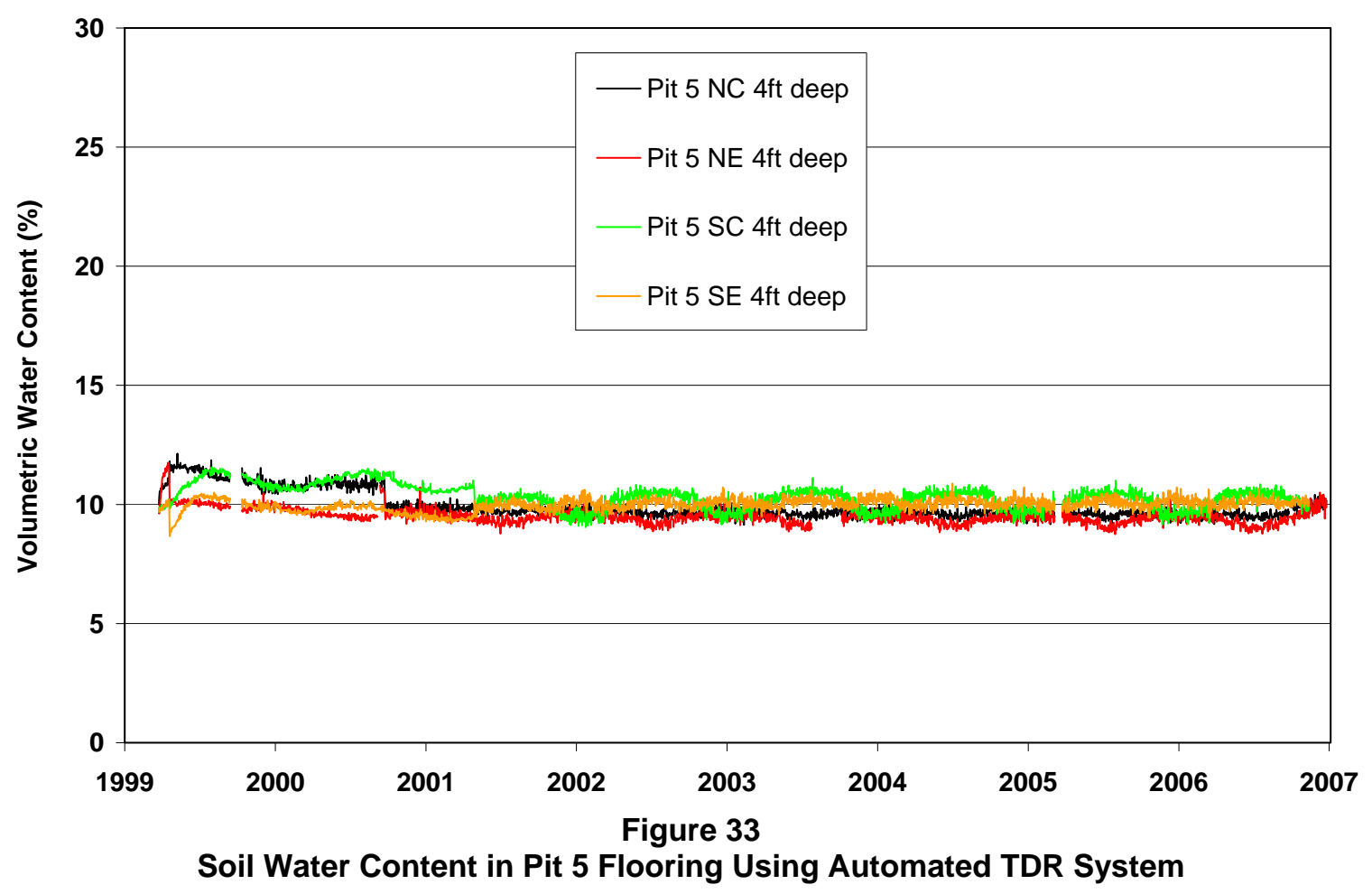


In 1999, TDR probes were also installed in the operational cover of Pit 3 at two sites (north and south) at depths ranging from 10 to $180 \mathrm{~cm}(0.3$ to $5.9 \mathrm{ft})$. The precipitation events, beginning in October 2004, infiltrated into the operational cover and percolated below the deepest probe at $180 \mathrm{~cm}(5.9 \mathrm{ft})$ at both the north location (Figure 34) and the south location (Figure 35) in early March 2005. This moisture is below the range of substantial surface E. During 2006, the gradual drying of the soil profile at Pit 3 by deep percolation continued. The water contents at and below $60 \mathrm{~cm}(2 \mathrm{ft})$ at both the north and south site remain higher than the water contents before October 2004.

In 2000, TDR probes were installed in the operational covers of Pits 4 and 5 at depths ranging from 20 to $180 \mathrm{~cm}$ (0.7 to $5.9 \mathrm{ft}$ ). The precipitation events beginning in October 2004 infiltrated into the operational cover of Pit 4 and Pit 5, and percolated deeper than the deepest probe at $180 \mathrm{~cm}(5.9 \mathrm{ft})$ at Pit 4 in March 2005 (Figure 36) and at Pit 5 in April 2005 (Figure 37). Similar to Pit 3 , the gradual drying of the soil profile continued. Because this moisture is below the range of substantial surface $\mathrm{E}$, the gradual drying is most likely due to downward percolation. Water contents at and below $30 \mathrm{~cm}(1 \mathrm{ft})$ at Pit 4 and at and below $45 \mathrm{~cm}(1.5 \mathrm{ft})$ at Pit 5 remain higher than the water contents before October 2004.

In December 2000, TDR probes were installed in the final vegetated cover of the U 3ax/bl waste disposal unit at the Area 3 RWMS. Eight vertically arranged TDR probes were installed at four locations at depths ranging from 30 to $244 \mathrm{~cm}$ (1 to $8 \mathrm{ft}$ ). Measured soil water contents for one location (East Nest A) in the U-3ax/bl waste cover are shown in Figure 38. The TDR data indicate that the soil water content in the cover generally decreased over time as the vegetation on the cover grew. The precipitation events beginning in October 2004 infiltrated into the final cover of U-3ax/bl, but the moisture has been removed without percolating below the 244-cm(8-ft)-deep sensor. Unlike the bare-soil operational covers on Pit 3, Pit 4, and Pit 5, the moisture was removed by ET.

Vegetation on the cover of U-3ax/bl is critical to its effectiveness. In the native environment, vegetative cover is about 12 percent. Vegetative cover is defined as the percent area covered by living plant material. Obtaining 12 percent vegetative cover on the soil caps is dependent upon the seed germination success and seedling survival of native plants seeded or transplanted on the soil cap. A quantitative analysis of the vegetative cover on the $\mathrm{U}-3 \mathrm{ax} / \mathrm{bl}$ soil cap is conducted annually in the spring. The percent cover for the established U-3ax/bl cover has ranged from 3.2 percent in 2003 to 20.2 percent in 2005. The percent cover in 2006 is 19.6 percent.

\section{Area 3 Drainage Lysimeter Facility}

The Area 3 Drainage Lysimeter Facility is immediately northwest of the U-3ax/bl waste disposal unit at the Area 3 RWMS (see Figure 3). This facility is designed to collect saturated gravity drainage from eight 3.05-m- (10-ft)-diameter by 2.44-m- (8-ft)-deep lysimeters. Each lysimeter is filled with native soil and packed to mimic the U-3ax/bl soil cover. Each lysimeter has eight TDR probes to measure moisture content depth profiles, paired with eight heat dissipation probes to measure soil water potential depth profiles. The probes are installed at $7.6 \mathrm{~cm}(0.25 \mathrm{ft}), 15 \mathrm{~cm}$ $(0.5 \mathrm{ft}), 30 \mathrm{~cm}(1 \mathrm{ft}), 61 \mathrm{~cm}(2 \mathrm{ft}), 91 \mathrm{~cm}(3 \mathrm{ft}), 122 \mathrm{~cm}(4 \mathrm{ft}), 183 \mathrm{~cm}(6 \mathrm{ft})$, and $244 \mathrm{~cm}(8 \mathrm{ft})$ deep. Measured water contents at the bottom of the lysimeters and drainage from the lysimeters provide an indirect measure of potential drainage from the U-3ax/bl soil cover. The lysimeter 


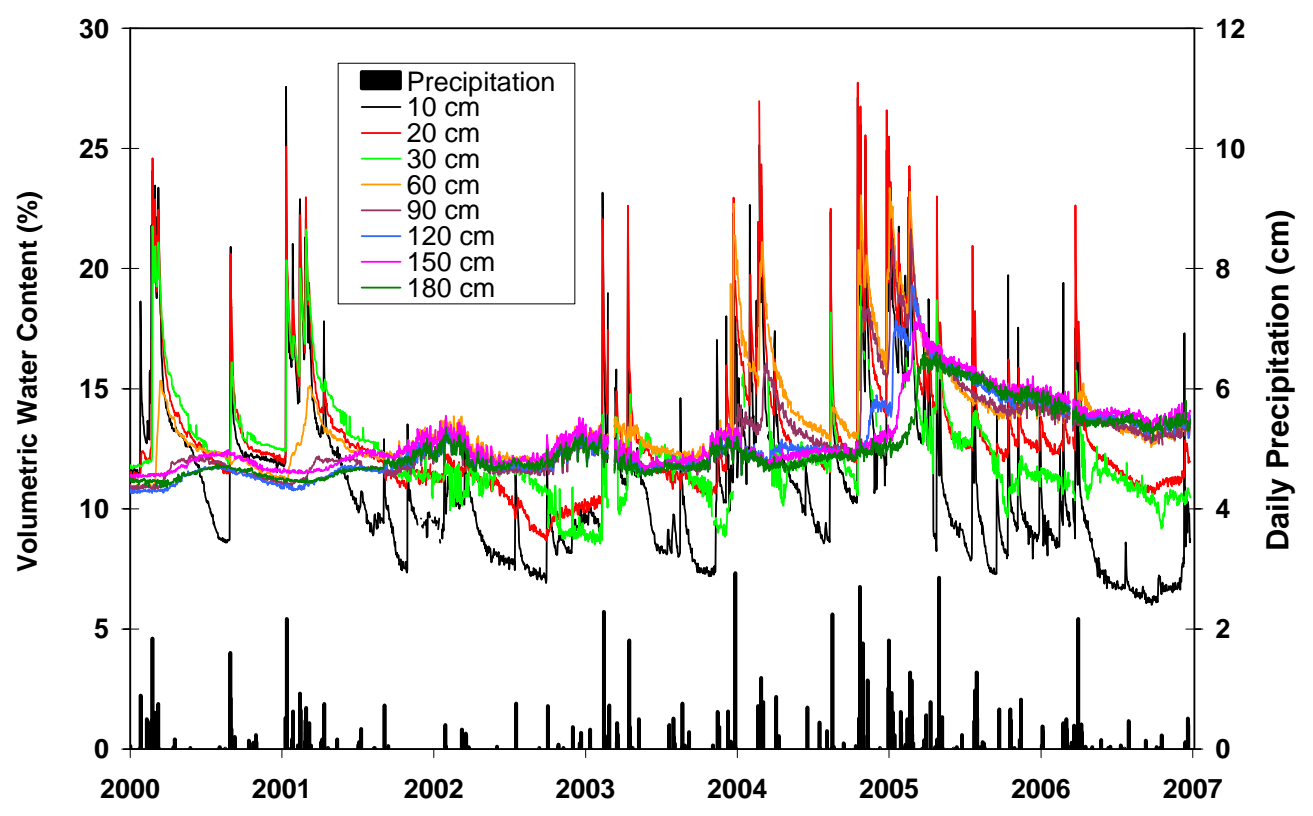

Figure 34

Soil Water Content in Pit 3 Waste Cover (North Site) Using an Automated TDR System

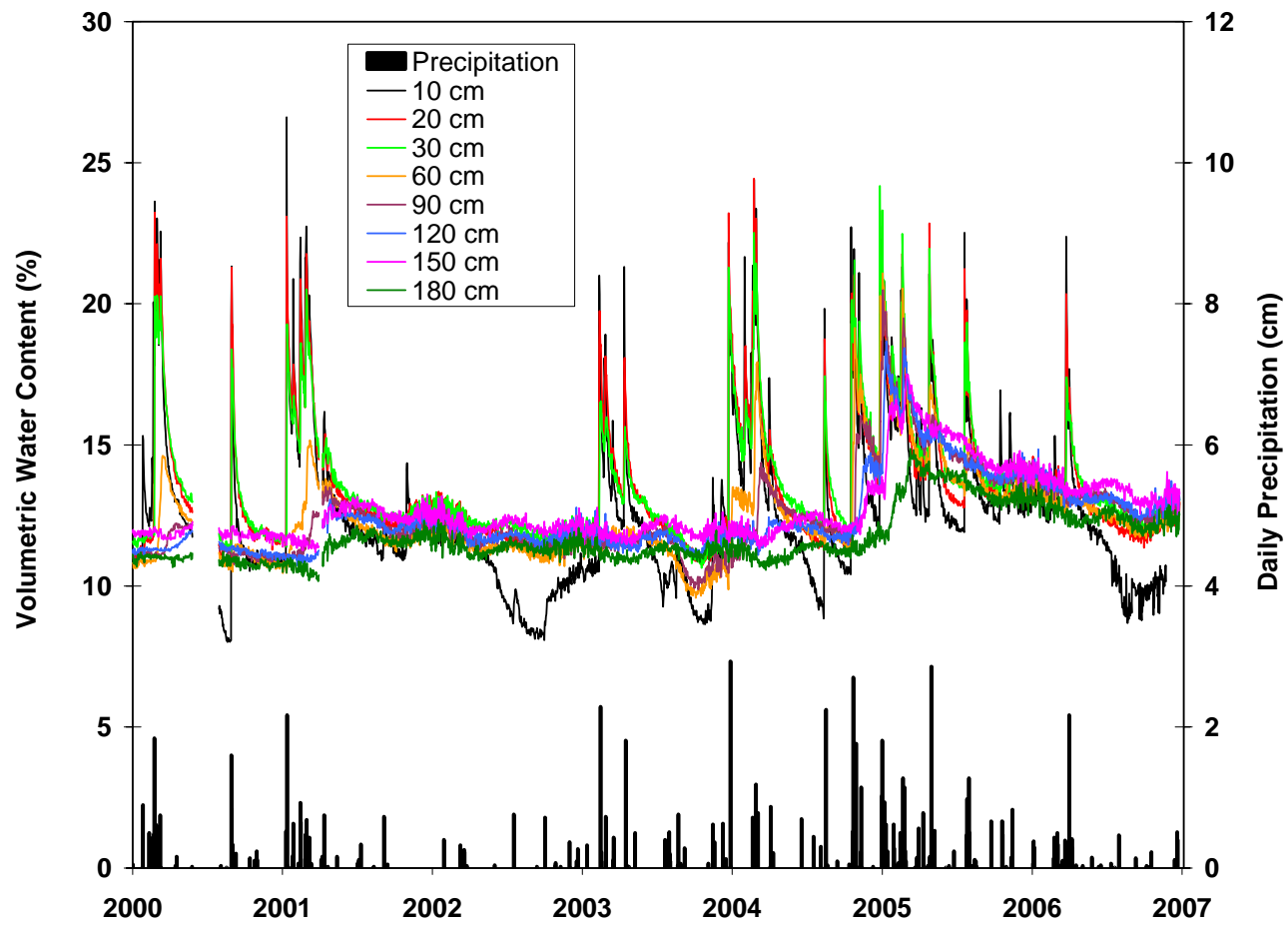

Figure 35

Soil Water Content in Pit 3 Waste Cover (South Site) Using an Automated TDR System 


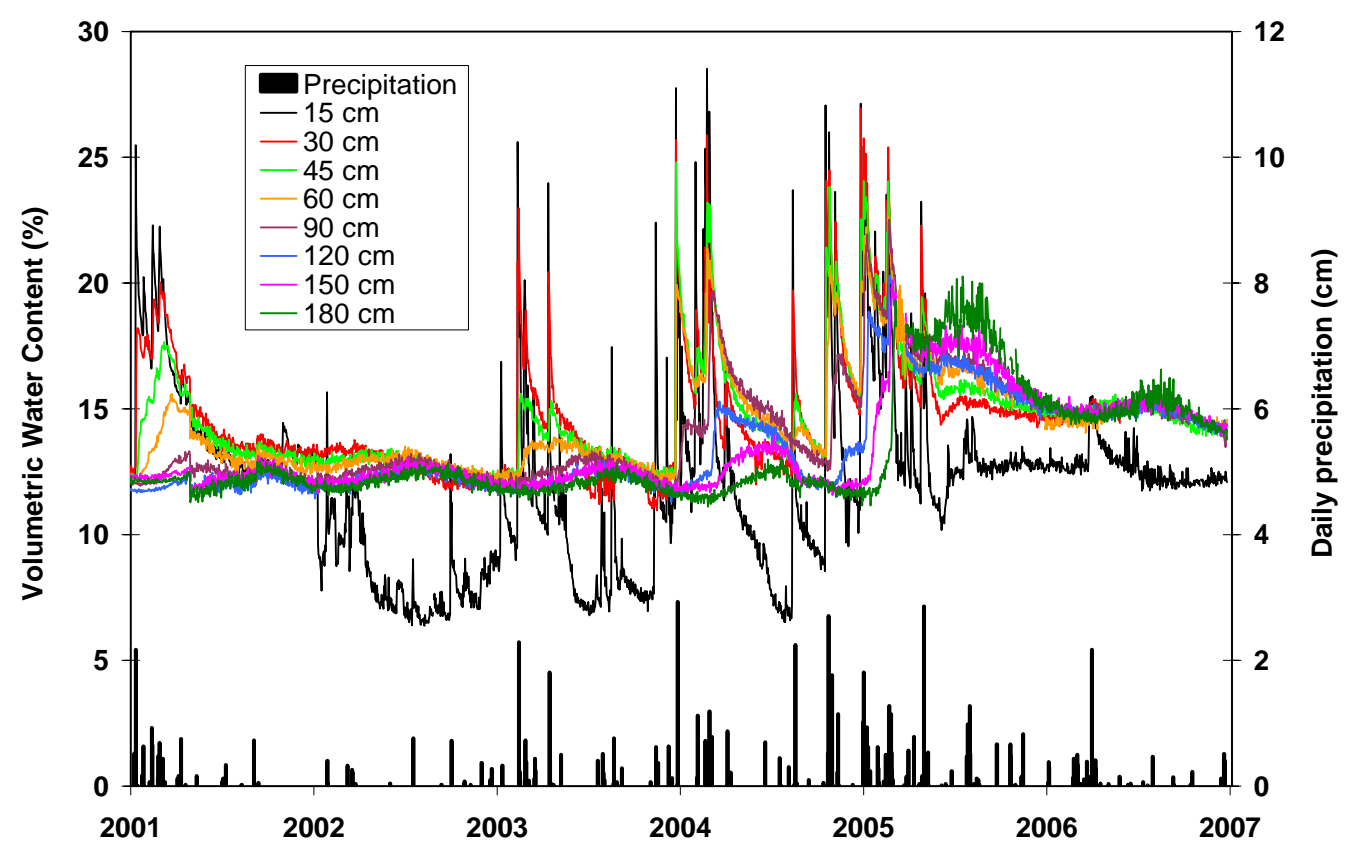

Figure 36

Soil Water Content in Pit 4 Waste Cover Using an Automated TDR System

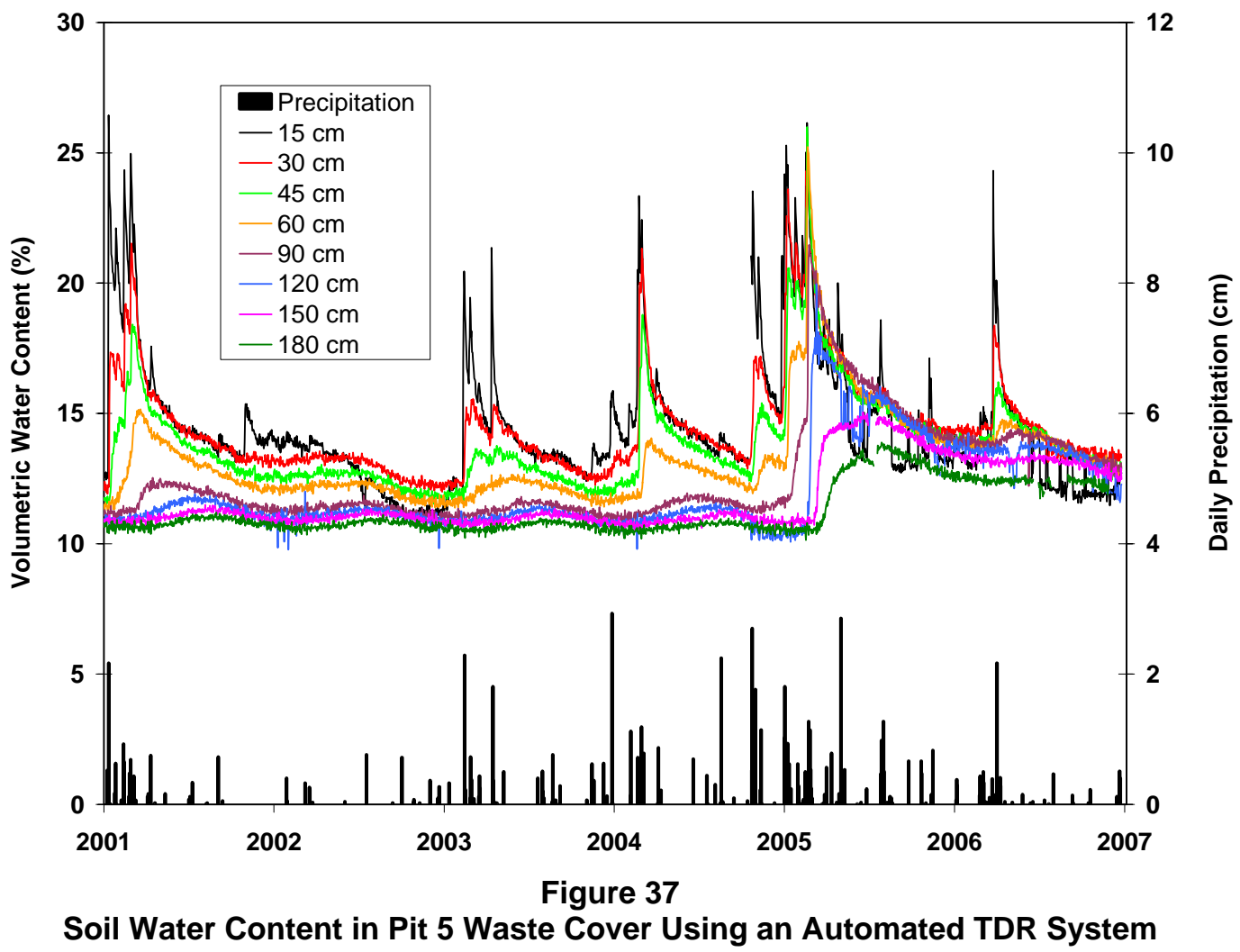




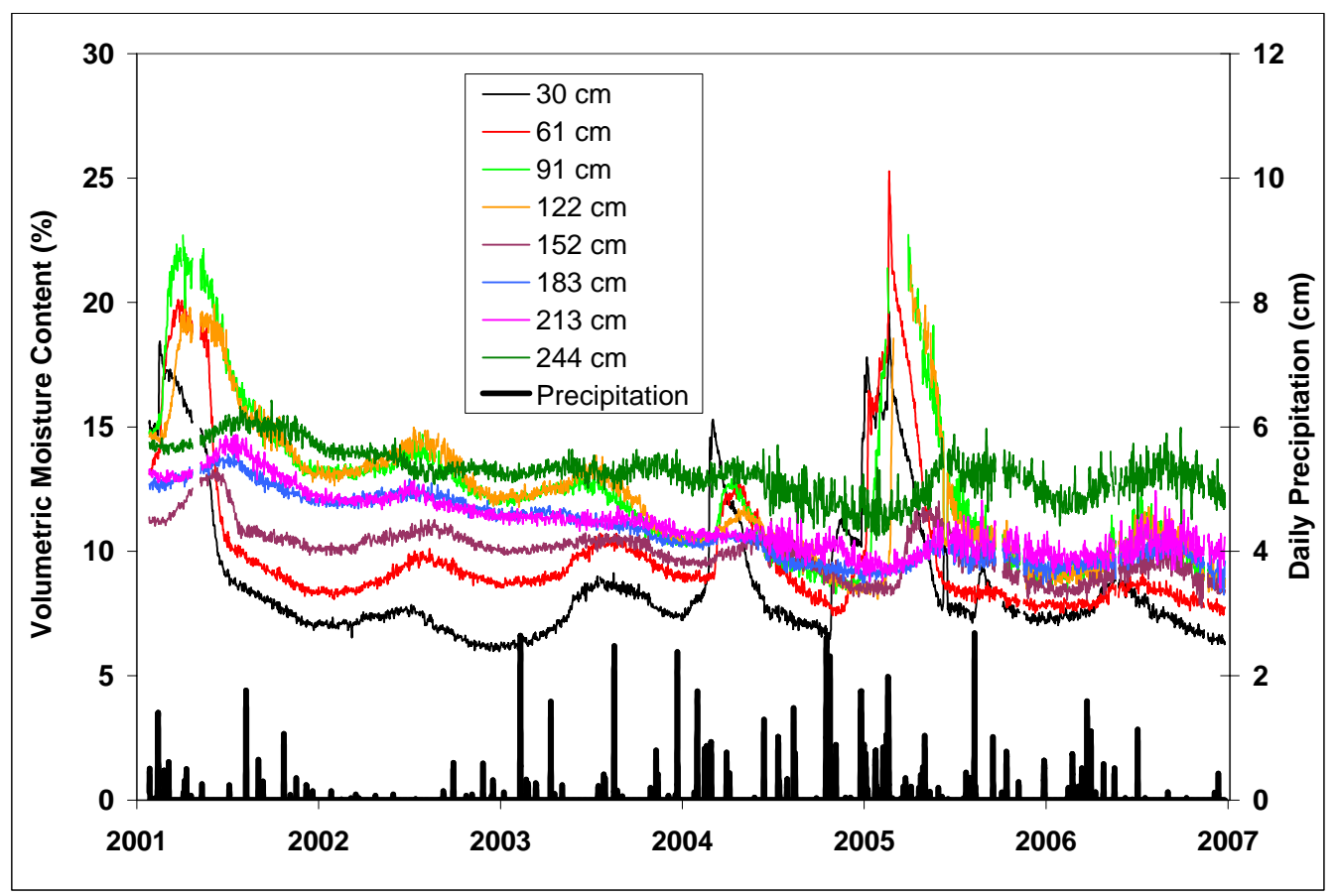

Figure 38

Soil Water Content in U-3ax/bl Waste Cover (East Nest A) Using a TDR System

facility was constructed to fulfill data needs including reducing uncertainty in the expected performance of monolayer-ET closure covers under various surface vegetation treatments and climatic change scenarios such as increased rainfall.

There are three surface vegetation treatments subject to two climate treatments on the lysimeters. The three surface vegetation treatments are bare-soil, invader species (primarily Russian thistle, halogeton, and tumble mustard), and native species (primarily shadscale, winterfat, ephedra, and Indian rice grass). The climate treatments are natural precipitation and three times natural precipitation. The three times natural precipitation lysimeters receive natural precipitation and are irrigated with an amount equal to two times natural precipitation.

The eight lysimeters are identified as Lysimeter A through Lysimeter $\mathrm{H}$. The irrigation and surface vegetation treatments to Lysimeters A, B, C, D, and F were not changed 2006. Lysimeter A is bare soil with natural precipitation, Lysimeter B is bare soil with three times natural precipitation, Lysimeter $C$ is invader species with natural precipitation, Lysimeter $\mathrm{D}$ is invader species with three times natural precipitation, and Lysimeter $\mathrm{F}$ is native species with three times natural precipitation. Prior to 2006, Lysimeter E was native species with natural precipitation, Lysimeter $\mathrm{G}$ was invader species with natural precipitation, and Lysimeter $\mathrm{H}$ was invader species with three times natural precipitation. The dry conditions after June 2005 resulted in the native plants on Lysimeter $\mathrm{E}$ dying and the surface being bare at the beginning of 2006. Lysimeters E, G, and $H$ were seeded with native species and mulched with straw netting in February 2006. The original invader species on Lysimeters $\mathrm{G}$ and $\mathrm{H}$ were removed prior to seeding. Lysimeters E, G, and $\mathrm{H}$ were irrigated for seed germination. The irrigation schedule at 
these lysimeters was approximately $2.6 \mathrm{~mm}$ (0.1 in.) per day from March 7, 2006, to May 14, 2006; 2.6 mm (0.1 in.) every other day from May 15, 2006, to June 2, 2006; and $2.6 \mathrm{~mm}$ (0.1 in.) every seven days from June 4, 2006, to August 26, 2006. Very few plants were established on these lysimeters. The lysimeter treatments are summarized in Table 1.

Table 1

Area 3 Drainage Lysimeter Treatments in 2006

\begin{tabular}{||cll||}
\hline \hline Lysimeter & \multicolumn{1}{c|}{ Climate } & \multicolumn{1}{c||}{ Surface Vegetation } \\
\hline A & natural precipitation & bare-soil \\
B & 3 times natural precipitation & bare-soil \\
C & natural precipitation & invader species \\
D & 3 times natural precipitation & invader species \\
E & irrigation for seed germination & native species \\
F & 3 times natural precipitation & native species \\
G & irrigation for seed germination & native species \\
H & irrigation for seed germination & native species \\
\hline
\end{tabular}

In 2006, there was $104.4 \mathrm{~mm}$ (4.1 in.) of precipitation at the Area 3 Drainage Lysimeter Facility. This is slightly higher than the $98.6 \mathrm{~mm}$ (3.9 in.) measured at the Area 3 RWMS Meteorology Station. An additional $226.2 \mathrm{~mm}$ (8.9 in.) of irrigation was applied to the irrigated Lysimeters B, $\mathrm{D}$, and, F. Lysimeters $\mathrm{E}$ and $\mathrm{G}$ received an additional $281.2 \mathrm{~mm}$ (11.1 in.) of irrigation, and Lysimeter $\mathrm{H}$ received and additional $318.0 \mathrm{~mm}$ (12.5 in.) of irrigation.

There were 571.6 liters of drainage from Lysimeter B during 2006. The equivalent depth of this drainage is $78.3 \mathrm{~mm}$ (3.1 in.). This drainage occurred every day from January 1, 2006, to August 6, 2006, and completely stopped on August 12, 2006. There was no drainage from any other lysimeter.

VWC at all measurement depths through time are illustrated in Figure 39 for bare-soil natural precipitation lysimeter (Lysimeter A), and in Figure 40 for the native species that had natural precipitation through 2005 lysimeter (Lysimeter E). Lysimeter A mimics bare-soil operational soil covers, and Lysimeter E mimics final monolayer-ET covers. During 2006, the moisture from natural precipitation that had percolated to the bottom of Lysimeter A remained in the lysimeter below $91 \mathrm{~cm}$ (3 ft) deep. The remaining moisture is being very slowly removed by surface evaporation. Lysimeter E has slightly elevated water contents from the additional irrigation added for seed germination. This moisture was not removed by ET because there were few plants.

Figure 41 shows the calculated total water storage for all eight lysimeters using TDR data. The two bare-soil lysimeters (Lysimeters A and B) could not remove the accumulated moisture by only $\mathrm{E}$, resulting in greater water storage. Lysimeter $\mathrm{E}$ also shows greater water storage because there were not many native plants to remove the water by ET and the lysimeter was irrigated for seed germination. The water storage in the other lysimeters did not increase, indicating that ET removed the water added in 2006. 


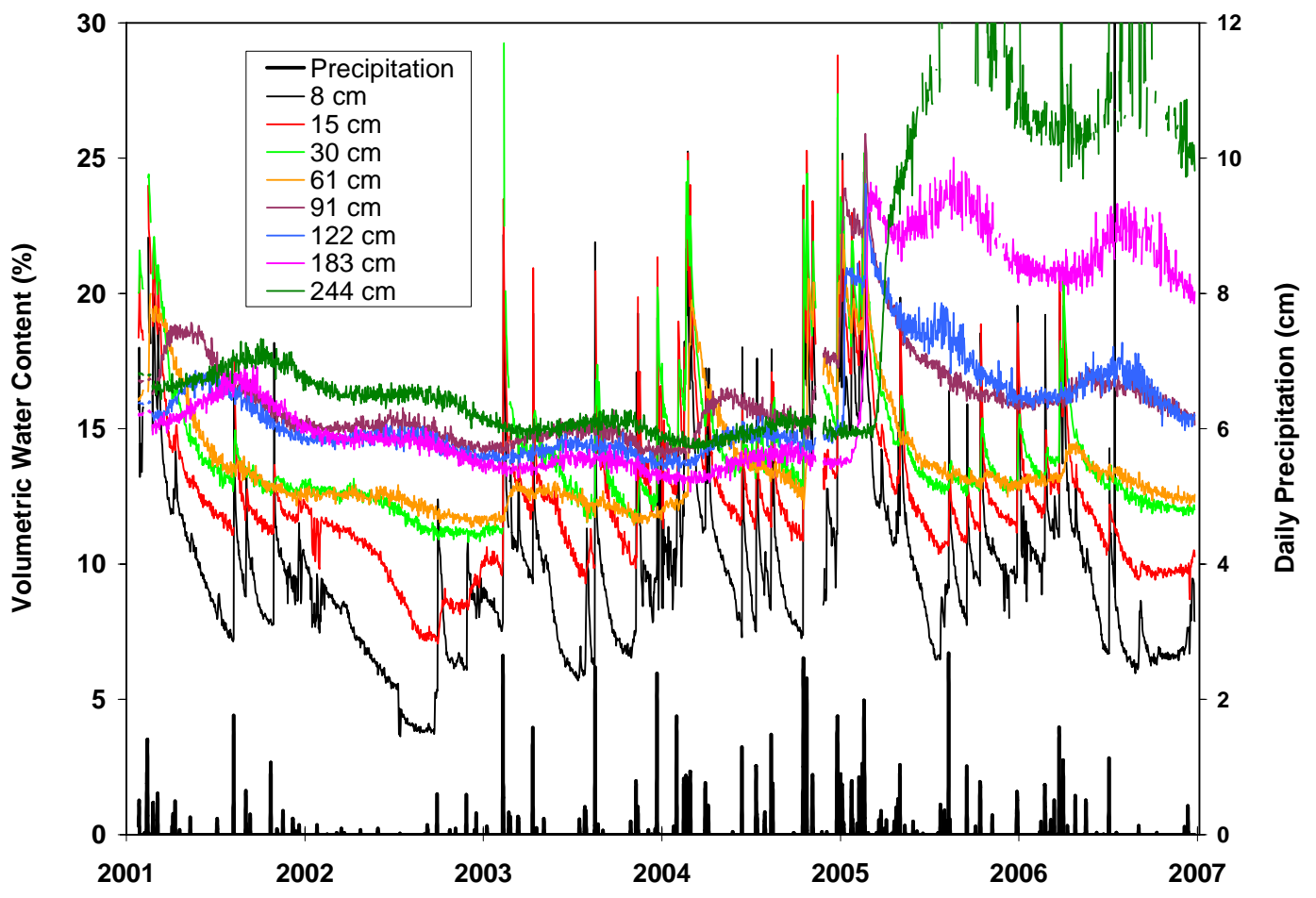

Figure 39

Soil Water Content in Bare Drainage Lysimeter (A) Using a TDR System

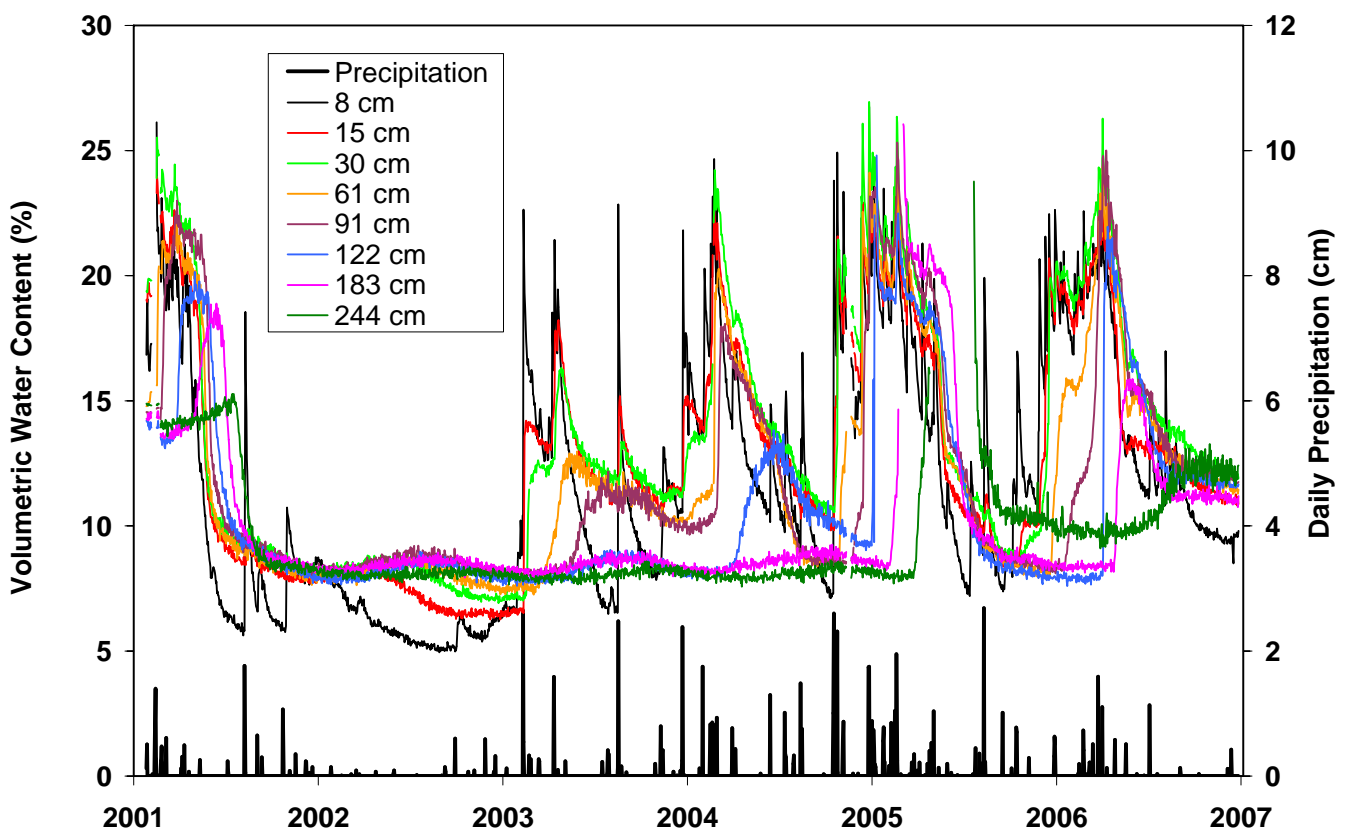

Figure 40

Soil Water Content Vegetated Drainage Lysimeter (E) Using TDR System 


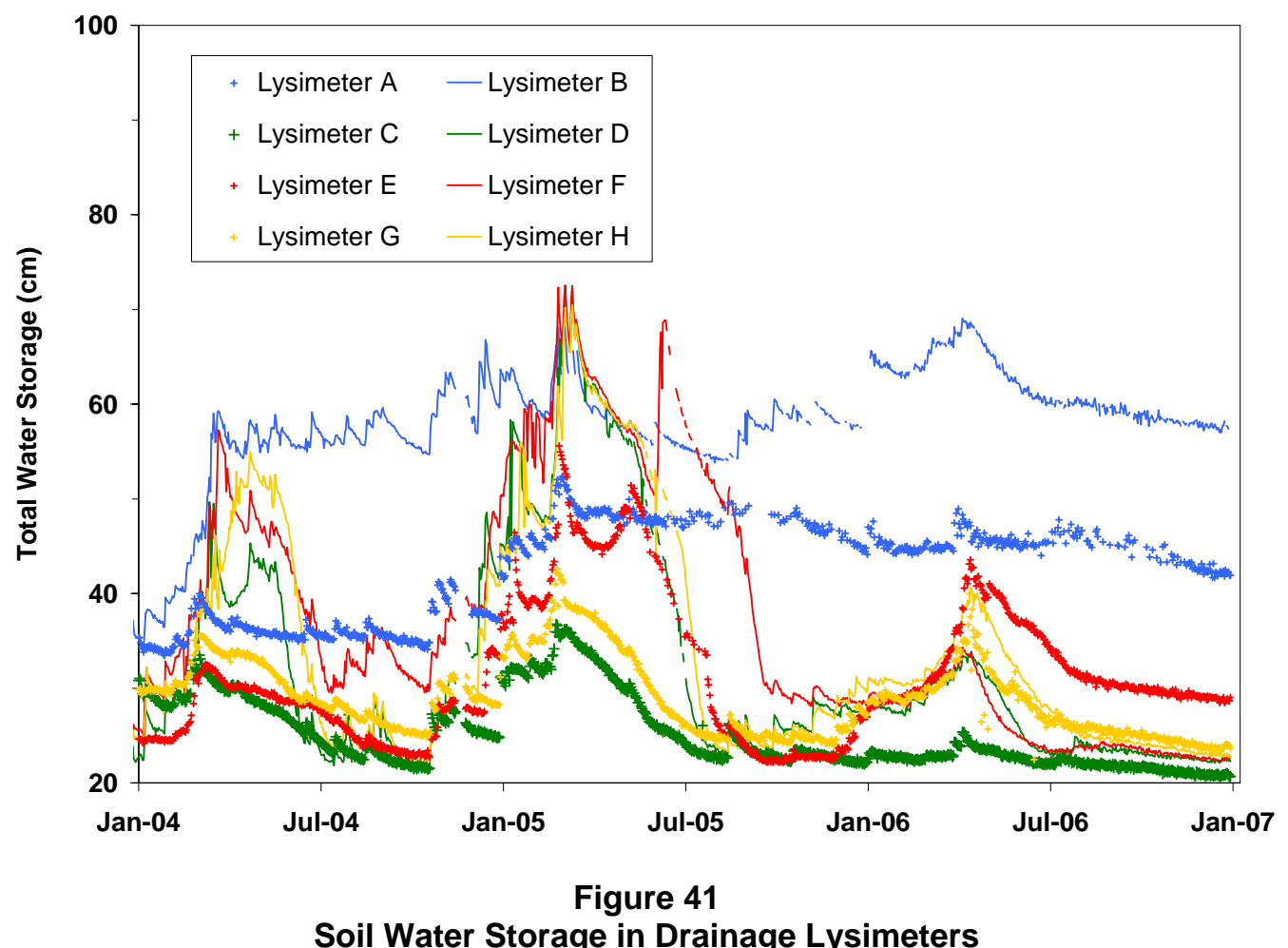

Soil Water Storage in Drainage Lysimeters

\section{Waste Cover Subsidence}

Subsidence monitoring is conducted to ensure that subsidence features are repaired to prevent the development of preferential water migration pathways through the waste covers. Subsidence monitoring also helps ensure that vadose zone monitoring data are representative of the entire RWMS. Waste Operations personnel observe and repair subsidence features. No subsidence was observed on the cover of Pits 3, 4, or 5 during 2006.

\section{Biota Monitoring Data}

No biota monitoring was conducted in 2006. Previous plant and animal (biota) monitoring at the Area 3 and Area 5 RWMSs help characterize and define trends in potential transport of radionuclides from buried waste. Tritium is predominantly observed because of its high mobility as tritiated water. The primary mechanisms that transport tritium upward through waste covers and into the atmosphere are gaseous diffusion, gaseous advection, bioturbation, plant uptake and transpiration, and soil evaporation. Sampling plant water for tritium provides a direct measure of the plant uptake of tritium. Analysis of plant tissues for gamma-emitting radionuclides, ${ }^{90} \mathrm{Sr}$, and alpha-emitting radionuclides provides information on potential plant intrusion into the waste and uptake of radionuclides.

The amount of tritium released into the atmosphere by plant transpiration is affected by several factors, including plant size, species, and available moisture. For example, plants under drought conditions may use water from deeper in the vadose zone and consequently have higher tritium concentrations due to the proximity of the water to the waste zone. For this reason, plants were generally sampled in late summer in prior years. Because of the dry conditions, measured plant 
water tritium concentrations may be a conservative representation of year-round concentrations. The range of tritium concentrations observed in vegetation from the last sampling event in 2005 were within the range of values observed during recent sampling periods (BN, 2001b, 2002, 2003; NSTec, 2006). Continued monitoring of biota can provide data to support PA efforts in predicting potential radionuclide movement over time. 


\section{CONCLUSIONS}

The 2006 environmental and operational monitoring data from the Area 3 and Area 5 RWMSs indicate that these facilities are performing as expected for the long-term isolation of buried waste. Direct radiation exposure data indicate a rate that is well below any dose of concern. Air monitoring data indicate that concentrations of radioactive materials in air remain below any concentrations of concern. Groundwater and vadose zone monitoring data indicate that the groundwater beneath the Area 5 RWMS is unaffected by the waste disposal operations. Soil gas monitoring at GCD-05U indicates little natural migration of tritium away from the waste at this disposal borehole. Vadose zone monitoring data indicate that vegetation prevents infiltrating precipitation from percolating deep into the soil by returning the moisture to the atmosphere by ET. Long-term vadose zone monitoring data from the weighing lysimeters indicate no drainage through the bottoms of the vegetated lysimeters. All 2006 monitoring data indicate that the Area 3 and Area 5 RWMSs are performing within expectations of the model and parameter assumptions for the facility PAs. 
This Page Intentionally Left Blank 


\section{REFERENCES}

Air Resources Laboratory/Special Operations and Research Division. http://www.sord.nv.doe.gov. Accessed March 21, 2007.

ARL, see Air Resources Laboratory.

Bechtel Nevada, 2005. Integrated Closure and Monitoring Plan for the Area 3 and Area 5 Radioactive Waste Management Sites at the Nevada Test Site. DOE/NV/11718--449-REV2. June 2005.

— 2003. Nevada Test Site 2002 Waste Management Monitoring Report, Area 3 and Area 5 Radioactive Waste Management Sites. DOE/NV/11718--822. June 2003.

_ - 2002. Nevada Test Site 2001 Waste Management Monitoring Report, Area 3 and Area 5 Radioactive Waste Management Sites. DOE/NV/11718--718. June 2002.

- 2001a. Closure Report for Corrective Action Unit 110: Area 3 RWMS U-3ax/bl Disposal Unit, Nevada Test Site, Nevada. DOE/NV--743. June 2001.

_ - 2001b. Nevada Test Site 2002 Waste Management Monitoring Report Area 3 and Area 5 Radioactive Waste Management Sites. DOE/NV/11718--582. June 2001.

- 1998. Hydrogeologic Characterization of the Unsaturated Zone at the Area 3 Radioactive Waste Management Site. Volume 1: “Data Interpretations.” Volume 2: “Data.” DOE/NV/11718--210. February 1998.

— , 1996. "Interim Geology Report, Area 3 Radioactive Waste Management Site DOE/Nevada Test Site, Nye County, Nevada.” Report to U. S. Department of Energy Nevada Operations Office. September 1996.

Blout, D. O., W. S. Birchfiel, D. P. Hammermeister, K. A. Zukosky, and K. D. Donnelson, 1995. Site Characterization Data from Area 5 Science Boreholes, NTS, Nye County, Nevada. DOE/NV/11432--170. Reynolds Electrical \& Engineering Co., Inc. February 1995.

BN, see Bechtel Nevada.

Campbell, G. S., 1977. “An Introduction to Environmental Biophysics.” Heidelberg Science Library. Springer-Verlag, New York. 159 pp. 
Cochran, J. R., W. E. Beyeler, D. A. Brosseau, L. H. Brush, T. J. Brown, B. Crowe, S. H. Conrad, P. A. Davis, T. Ehrhorn, T. Feeney, B. Fogleman, D. P. Gallegos, R. Haaker, D. Kalinina, L. L. Price, D. P. Thomas, and S. Wirth, 2001. Compliance Assessment Document for the Transuranic Wastes in the Greater Confinement Disposal Boreholes at the Nevada Test Site. Sandia Report SAND2001-2977. Sandia National Laboratories. September 2001.

Desotell, L. T., D. B. Hudson, V. Yucel, and J. T. Carilli, 2006. "Use of Long-Term Lysimeter Data in Support of Shallow Land Waste Disposal Cover Design. In: Proceedings of the Waste Management '06 Conference, Tucson, Arizona, February 26 to March 2, 2006.

DOE, see U.S. Department of Energy.

Doorenbos, J., and W. O. Pruitt, 1977. “Guidelines for Prediction Crop Water Requirements.” FAO Irrigation and Drainage Paper No. 24, 2d ed. Rome, Italy: U.N. Food and Agricultural Organization.

Levitt, D. G., M. J. Sully, B. L. Dozier, and C. F. Lohrstorfer, 1999. “Determining the Performance of an Arid Zone Radioactive Waste Site Through Site Characterization, Modeling, and Monitoring." In: Proceedings of the Waste Management '99 Conference, Tucson, Arizona, February 28 to March 4, 1999.

Levitt D. G., and V. Yucel. 2002. "Potential Groundwater Recharge and the Effects of Soil Heterogeneity on Flow at Two Radioactive Waste Management Sites at the Nevada Test Site.” In: Proceedings of the 2002 International Groundwater Symposium, Berkeley, California. March 25-28, 2002.

National Security Technologies, LLC, 2007. Nevada Test Site 2006 Data Report: Groundwater Monitoring Program, Area 5 Radioactive Waste Management Site. DOE/NV/25946-138. February 2007.

_ - 2006. Nevada Test Site 2005 Waste Management Monitoring Report, Area 3 and Area 5 Radioactive Waste Management Sites. DOE/NV/11718--1241 and DOE/NV25946--021. August 2006.

NSTec, see National Security Technologies, LLC.

Plannerer, H. N., 1996. Siting Criteria for Angle Drilling Under the U-3ah/at Disposal Unit. Los Alamos National Laboratory Report LA-UR-96-1679. May 13, 1996.

REECo, see Reynolds Electrical \& Engineering Co., Inc.

Reynolds Electrical \& Engineering Co., Inc., 1994. Site Characterization and Monitoring Data from Area 5 Pilot Wells, Nevada Test Site, Nye County, Nevada. DOE/NV/11432--74. February 1994. 
- 1993a. Hydrogeologic Data for Existing Excavations at the Area 5 RWMS, Nevada Test Site, Nye County, Nevada. DOE/NV/11432--40. December 1993.

— 1993b. "Hydrogeologic Data for Science Trench Boreholes at the Area 5 RWMS, Nevada Test Site, Nye County, Nevada.” December 1993.

Schmeltzer, J. S., L. E. Barker, and D. O. Blout, 1996. Site Characterization Data from the U-3ax/bl Exploratory Boreholes at the NTS. DOE/NV/11718--003. Bechtel Nevada. 1996.

Shott, G. J., L. E. Barker, S. E. Rawlinson, M. J. Sully, and B. A. Moore, 1998. Performance Assessment for the Area 5 RWMS at the NTS, Nye County, Nevada. Revision 2.1. DOE/NV/11718--176. Bechtel Nevada. January 1998.

Shott, G. J., V. Yucel, M. J. Sully, L. E. Barker, S. E. Rawlinson, and B. A. Moore, 1997. Performance Assessment/Composite Analysis for the Area 3 RWMS at the NTS, Nye County, Nevada. Revision 2.1. DOE/NV--491-REV 2.1. Bechtel Nevada. September 1997.

Snyder, K. E., R. D. Van Remortel, D. L. Gustafson, H. E. Huckins-Gang, J. J. Miller, S. E. Rawlinson, and S. M. Parsons, 1995. "Surficial Geology and Landscape Development in Northern Frenchman Flat, Area 5 RWMS, DOE NTS.” Interim Summary and Soil Data Report. Raytheon Services Nevada. September 1995.

Tyler, S. W., J. B. Chapman, S. H. Conrad, D. P. Hammermeister, D. O. Blout, J. J. Miller, M. J. Sully, and J. M Ginanni, 1996. "Soil-Water Flux in the Southern Great Basin, United States: Temporal and Spatial Variations Over the Last 120,000 Years.” Water Resources Research 32(6):1481-1499.

U.S. Department of Energy, 2006. Nevada Test Site Environmental Report 2005. DOE/NV/11718--1214. National Security Technologies, LLC. DOE/NV/25946--007. October 2006.

— 2003. Nevada Test Site Routine Radiological Environmental Monitoring Plan. DOE/NV/11718--804. Bechtel Nevada. June 2003.

Warren, R. W., and R. F. Grossman, 2007. National Emission Standards for Hazardous Air Pollutants, Calendar Year 2006. DOE/NV/ 25946--171. National Security Technologies, LLC. June 2007. 
This Page Intentionally Left Blank 


\section{DISTRIBUTION}

U. S. Department of Energy, National Nuclear Security Administration Nevada Site Office

Jhon Carilli

LLW Federal Sub-Project Director, Waste Management Project

4

U.S. Department of Energy

National Nuclear Security Administration

Nevada Site Office

P.O. Box $98518 \mathrm{M} / \mathrm{S} 505$

Las Vegas, NV 89193-8518

E. F. Di Sanza

Federal Project Director, Waste Management Project

U.S. Department of Energy

National Nuclear Security Administration

Nevada Site Office

P.O. Box 98518 M/S 505

Las Vegas, NV 89193-8518

Ken Small

1

RCRA Program Manager, Waste Management Project

U.S. Department of Energy

National Nuclear Security Administration

Nevada Site Office

P.O. Box 98518 M/S 505

Las Vegas, NV 89193-8518

U.S. Department of Energy

$1 \mathrm{CD}$

National Nuclear Security Administration

Nevada Site Office

Technical Library

P.O. Box 98518, M/S 505

Las Vegas, NV 89193-8518

U.S. Department of Energy

$1 \mathrm{CD}$

National Nuclear Security Administration

Nevada Site Office

Public Reading Facility, M/S 400

c/o Nuclear Testing Archive

P.O. Box 98521

Las Vegas, NV 89193-8521

U.S. Department of Energy

Office of Scientific and Technical Information

1 electronic copy

P.O. Box 62

Oak Ridge, TN 37831-0062 
National Security Technologies, LLC

Terry Brooker

National Security Technologies, LLC

P.O. Box 98518, M/S NLV-022

Las Vegas, NV 89193-8521

Lloyd Desotell

National Security Technologies, LLC

P.O. Box 98521, M/S NLV-083

Las Vegas, NV 89193-8521

Dudley Emer

National Security Technologies, LLC

P.O. Box 98521, M/S NTS-306

Las Vegas, NV 89193-8521

David Hudson

National Security Technologies, LLC

P.O. Box 98521, M/S NTS-273

Las Vegas, NV 89193-8521

Charles Lohrstorfer

National Security Technologies, LLC

P.O. Box 98521, M/S NTS-188

Las Vegas, NV 89193-8521

Steve Nacht

National Security Technologies, LLC

P.O. Box 98521, M/S NLV-083

Las Vegas, NV 89193-8521

Theodore Redding

National Security Technologies, LLC

P.O. Box 98521, M/S NTS-273

Las Vegas, NV 89193-8521

Greg Shott

National Security Technologies, LLC

P.O. Box 98521, M/S NLV-081

Las Vegas, NV 89193-8521

Shirley Smith

National Security Technologies, LLC

P.O. Box 98518, M/S NLV-083

Las Vegas, NV 89193-8521 
Matthew Weaver

National Security Technologies, LLC

P.O. Box 98521, M/S NTS-273

Las Vegas, NV 89193-8521

Denise Wieland

National Security Technologies, LLC

P.O. Box 98521, M/S NLV-083

Las Vegas, NV 89193-852

Vefa Yucel

National Security Technologies, LLC

P.O. Box 98518, M/S NLV-083

Las Vegas, NV 89193-8521 


\section{This Page Intentionally Left Blank}

